\title{
The oxygen isotope evolution of seawater: A critical review of a long-standing controversy and an improved geological water cycle model for the past 3.4 billion years
}

\author{
Jasmine B.D. Jaffrés $^{\mathrm{a}, *}$, Graham A. Shields ${ }^{\mathrm{a}, 1}$, Klaus Wallmann ${ }^{\mathrm{b}}$ \\ ${ }^{a}$ School of Earth Sciences, James Cook University, Townsville, QLD 4811, Australia \\ b GEOMAR Research Center, Wischhofstrasse 1-3, 24148 Kiel, Germany
}

Received 7 April 2006; accepted 16 April 2007

Available online 3 May 2007

\begin{abstract}
Controversy over the oxygen isotope composition of seawater began in the 1950's, since which time there has been no agreement over whether the oxygen isotope composition of the oceans has changed over time. Resolving this uncertainty would allow the $\delta^{18} \mathrm{O}$ values of demonstrably well preserved marine authigenic precipitates to be used to reconstruct surface climate trends back to early Archean times and would help towards a more quantitative description of Earth's global water cycle on geological time scales.

Isotopic studies of marine carbonate and silica reveal a trend of increasing $\delta^{18} \mathrm{O}$ values with decreasing age since the Archean. This trend has been interpreted by some to reflect a progressive increase in seawater $\delta^{18} \mathrm{O}$ through time; however, it is generally accepted on the basis of ophiolite studies and theoretical considerations that seawater $\delta^{18} \mathrm{O}$ cannot change significantly because of the buffering effects of ocean crust alteration at mid-ocean ridges. As a result many alternative interpretations have been proposed, including meteoric alteration; warmer paleoclimates; higher seawater $\mathrm{pH}$; salinity stratification and biased sampling.

Here we review these interpretations in the light of an updated compilation of marine carbonate $\delta^{18} \mathrm{O}$ from around the world, covering the Phanerozoic and Precambrian rock records. Recent models of the geological water cycle demonstrate how long-term trends in chemical weathering and hydrothermal circulation can indeed influence the O-isotope composition of the global ocean to the extent necessary to explain the carbonate $\delta^{18} \mathrm{O}$ trend, with residual variation attributed to climatic fluctuations and postdepositional alteration.

We present the further development of an existing model of the geological water cycle. In the model, seawater $\delta^{18} \mathrm{O}$ increased from about $-13.3 \%$ to $-0.3 \%$ over a period of $3.4 \mathrm{Ga}$, with average surface temperatures fluctuating between $10{ }^{\circ} \mathrm{C}$ to $33{ }^{\circ} \mathrm{C}$, which is consistent with known biological constraints. Similar temperature variations are also obtained, although with higher starting seawater $\delta^{18} \mathrm{O}$ composition, when more conservative approaches are used that take into account the systematic effects of diagenetic alteration on mean calcite $\delta^{18} \mathrm{O}$ values. In contrast to much published opinion, the average $\delta^{18} \mathrm{O}$ value of ocean crust in the model remained relatively unchanged throughout all model runs. Invariable ophiolite $\delta^{18} \mathrm{O}$ values can, therefore, not be used as a definitive argument against changing seawater $\delta^{18} \mathrm{O}$.

The most likely explanation for the long-term trend in seawater $\delta^{18} \mathrm{O}$ invokes two stepwise increases in the ratio of high- to lowtemperature fluid/rock interactions. An initial increase may have occurred close to the Archean-Proterozoic boundary, but a possibly more significant increase took place near the Proterozoic-Phanerozoic boundary. Possible explanations for extremely low
\end{abstract}

\footnotetext{
* Corresponding author. Fax: +61 747251501.

E-mail address: jasmine.jaffres@jcu.edu.au (J.B.D. Jaffrés).

${ }^{1}$ Present address: Geologisch-Paläontologisches Institut, Westfälische Wilhelms-Universität, 48149 Münster, Germany.
} 
seawater $\delta^{18} \mathrm{O}$ during the Archean include higher continental weathering rates caused by a combination of higher atmospheric $p \mathrm{CO}_{2}$ (necessarily combined with high $\mathrm{CO}_{2}$ outgassing rates), a greater abundance of relatively easily weathered volcanic rocks in greenstone belts and partial emergence of spreading ridges. The second increase may have been caused by the suppression of lowtemperature overprinting of ocean crust alteration by the formation of a thick sediment cover on ridge flanks due to the emergence of shelly plankton at the beginning of the Phanerozoic. Postulated increases in spreading ridge depths since the Archean would also have enhanced the efficiency of vertical heat flux and changed the depth at which hydrothermal fluids boil, both of which would favour high- over low-temperature interactions with time.

(C) 2007 Elsevier B.V. All rights reserved.

Keywords: marine carbonates; $\delta^{18} \mathrm{O}$ record; seawater $\delta^{18} \mathrm{O}$; paleotemperature; diagenesis; box modelling

\section{Seawater $\delta^{18} \mathrm{O}$ : an old controversy}

Variations in oxygen isotopic composition are typically expressed in terms of $\delta^{18} \mathrm{O}$, which represents the per mil (\%) difference in the ratio ${ }^{18} \mathrm{O} /{ }^{16} \mathrm{O}$ between a water or rock sample and Vienna Standard Mean Ocean Water (V-SMOW) or between a carbonate sample and the international carbonate isotope standard (V-PDB). The $\delta^{18} \mathrm{O}$ value of the comparatively well-mixed and isotopically homogeneous modern ocean is around $-0.28 \pm 0.5 \%{ }_{\text {SMOw }}$ (Shackleton and Kennett, 1975), with a global range of $-1.5 \%{ }_{\text {SMow }}$ to $1.8 \%{ }^{\circ}$ SMOw (cf. Carpenter and Lohmann, 1995: Table 1), while the $\delta^{18} \mathrm{O}$ value of an ice-free planet would be about $-1.4 \%$ o (Lhomme et al., 2005). Subtle variations in surface ocean $\delta^{18} \mathrm{O}$ correlate with salinity, and thus exhibit a strong latitudinal variation due to evaporation and precipitation (Schmidt et al., 1999; Waelbroeck et al., 2005). As a consequence, saline water masses with elevated $\delta^{18} \mathrm{O}$ values are generally found in tropical regions of intense evaporation, while low-salinity waters of lower $\delta^{18} \mathrm{O}$ predominate at high latitudes due to rainfall exceeding evaporation and melt water mixing. Further secular variations in global ocean $\delta^{18} \mathrm{O}$, limited to $0 \pm 1 \%{ }_{\text {SMOw }}$, follow glacial-interglacial cycles. The $\delta^{18} \mathrm{O}$ of ice is generally much lower than that of the ocean because high-latitude precipitation is significantly depleted in ${ }^{18} \mathrm{O}$, so that ice volume changes lead to an increase in seawater $\delta^{18} \mathrm{O}$ (to about $+1 \%_{\text {SMOw }}$ ) during glacial maxima and a decrease in seawater $\delta^{18} \mathrm{O}$ (down to about $-1 \%{ }^{\circ}$ SMow) during periods of no ice storage whatsoever (Shackleton and Kennett, 1975).

Although changes in the oxygen isotope composition of the ocean are well understood for at least the past few million years, the factors that control the absolute ${ }^{18} \mathrm{O} /{ }^{16} \mathrm{O}$ ratio and its evolution in the global surface water reservoir (groundwater, ice, lakes, seawater) over longer, geological time scales are highly controversial. During most of Earth history, this surface water re- servoir corresponded to seawater alone, while other water reservoirs can be considered negligible because of the absence of substantial ice on the continents (Frakes, 1979; Frakes and Francis, 1988). It has been debated for several decades whether seawater $\delta^{18} \mathrm{O}$ is buffered by submarine hydrothermal processes to about $0 \pm 1 \%^{\circ}$ SMOW (Muehlenbachs and Clayton, 1976; Gregory and Taylor, 1981; Gregory, 1991; Muehlenbachs, 1998) or whether the lower $\delta^{18} \mathrm{O}$ values of most ancient marine authigenic precipitates such as carbonate rocks reflect the fact that seawater $\delta^{18} \mathrm{O}$ has varied significantly over time (Weber, 1955; Perry, 1967; Veizer et al., 1986; Qing and Veizer, 1994; Veizer et al., 1997; Wallmann, 2001, 2004). The general assumption by most geochemists that seawater $\delta^{18} \mathrm{O}$ has always remained the same (e.g. Holland, 2004) means that anomalously low $\delta^{18} \mathrm{O}$ values in ancient marine carbonates are interpreted to reflect either that ancient oceans were implausibly warm (e.g. Knauth and Lowe, 2003) or that all ancient carbonate rocks have suffered pervasive alteration since deposition. This uncertainty has led to widespread scepticism regarding the veracity of most oxygen isotope data, to the extent that the $\delta^{18} \mathrm{O}$ compositions of ancient rocks are widely prejudged to be meaningless and so are commonly left unreported. As a result, the tremendous potential of oxygen isotope systematics for an improved understanding of paleoclimates and the geological water cycle remains untapped.

Published studies show a trend of continuously increasing $\delta^{18} \mathrm{O}$ values of brachiopods, marine cements, carbonate rocks, cherts, marine phosphorites and phosphatic fossils from the Early Cambrian to the present (Baertschi, 1957; Degens and Epstein, 1962; Keith and Weber, 1964; Perry, 1967; Longinelli and Nuti, 1968a; Veizer and Hoefs, 1976; Knauth and Lowe, 1978; Luz et al., 1984; Popp et al., 1986a; Veizer et al., 1986; Lohmann and Walker, 1989; Gao and Land, 1991; Wadleigh and Veizer, 1992; Qing and Veizer, 1994; Veizer, 1995; Veizer et al., 1997, 1999; Lécuyer and Allemand, 1999; Wallmann, 2001; Knauth, 2005). On 
this secular trend are superimposed recurrent oscillations, where maxima correlate with independently reconstructed cold periods and glaciations (Azmy et al., 1998; Veizer et al., 1999, 2000; Wallmann, 2001). Low $\delta^{18} \mathrm{O}$ values are also typical of almost the entire Precambrian sedimentary record.

This trend to higher $\delta^{18} \mathrm{O}$ with time is particularly evident in the chert O-isotope record. In Archean samples, maximum $\delta^{18} \mathrm{O}_{\mathrm{SMO}}$ values in chert range from about $+20 \%$ to $+22.1 \%$ (Knauth and Lowe, 1978; Perry et al., 1978). Paleoproterozoic cherts display maximum $\delta^{18} \mathrm{O}$ values of $+24.0 \%$ o to $+24.7 \%$ o (Becker and Clayton, 1976; Winter and Knauth, 1992). By comparison, Devonian cherts exhibit $\delta^{18} \mathrm{O}$ values of $+30 \%$ to $+34 \%$ o (Jones and Knauth, 1979), while a representative value for Eocene deep sea chert is around $+35 \%$ (Perry and Lefticariu, 2003). This increasing trend could reflect to some currently unknown extent the changing depositional settings of cherts from very shallow to deep marine environments across the Proterozoic-Phanerozoic transition (Maliva et al., 1989; Perry and Lefticariu, 2003), thus complicating further interpretation. Nevertheless, the $\delta^{18} \mathrm{O}$ values of sedimentary carbonate rocks, the record of which is both more complete than the chert record and less ambiguously marine in origin, are also significantly lower in Paleozoic and Precambrian rocks compared with their more recent counterparts (Veizer and Hoefs, 1976; Veizer et al., 1997).

Three main hypotheses have been put forward to explain the observed Phanerozoic trend: either the trend is a secondary feature caused by post-depositional alteration (Degens and Epstein, 1962; Keith and Weber, 1964), a primary characteristic indicating that the ancient ocean was ${ }^{18} \mathrm{O}$ depleted (Weber, 1955; Perry, 1967; Walker and Lohmann, 1989; Veizer, 1999; Veizer et al., 1999; Wallmann, 2001; Kasting et al., 2006) and/or that surface temperatures were higher during the early Phanerozoic (Knauth and Epstein, 1976; Jean-Baptiste et al., 1997). Because ${ }^{18}$ O-depletion in brachiopods and other marine fossils is a global phenomenon occurring independently of the age, ecology of fauna, and mineralogy of the fossils' hard parts, it seems unlikely that the $\delta^{18} \mathrm{O}$ trend is caused purely by diagenetic alteration (Lécuyer and Allemand, 1999; Wenzel et al., 2000). In this case, the wide ranges (around $4-6 \%$ ) exhibited by the $\delta^{18} \mathrm{O}$ values of contemporaneous fossil brachiopod samples may have arisen due to paleolatitudinal variations in $\delta^{18}$ O (Popp et al., 1986a; Veizer et al., 1997; Brand et al., 2003). Unrealistically high ocean temperatures would be obtained if one assumes that the carbonate $\delta^{18} \mathrm{O}$ trend is a result of variations in temperature (Veizer et al., 1986; Carpenter et al., 1991; Lécuyer and Allemand, 1999), and so changing seawater $\delta^{18} \mathrm{O}$ is increasingly favoured as the primary explanation for the first-order trend (Veizer et al., 1999, 2000).

One additional but apparently less favoured explanation for the trend is that the early ocean was salinitystratified as opposed to thermally-stratified (Railsback, 1990; Allison et al., 1998). It is hypothesised that warm saline bottom waters of the early oceans were generated from brines formed by extensive evaporation at lowand mid-latitudes (Brass et al., 1982; Wilde and Berry, 1984; Railsback et al., 1990), leaving the waters above the thermocline depleted in ${ }^{18} \mathrm{O}$ (Railsback, 1990). Alternatively, river-runoff and lack of tidal mixing may have resulted in local, salinity-stratified surface waters of low $\delta^{18} \mathrm{O}$ (Allison et al., 1998). More recently, $\mathrm{pH}$ was found to affect the $\delta^{18} \mathrm{O}$ of calcium carbonate, suggesting that $\mathrm{pH}$ variations could explain parts of the $\delta^{18} \mathrm{O}$ oscillations seen during the Phanerozoic (Spero et al., 1997).

Several studies indicate that the marine carbonate $\delta^{18} \mathrm{O}$ increase did not occur at a uniform rate but that $\delta^{18} \mathrm{O}$ values displayed several major shifts (Hudson and Anderson, 1989; Railsback, 1990; Qing and Veizer, 1994; Fricke et al., 1998). Elevated $\delta^{18} \mathrm{O}$ values have been recorded from several late Ordovician samples of various brachiopod genera and marine cements, coinciding with glaciation and the major mass extinction event at the end of the Ordovician (Veizer and Hoefs, 1976; Hudson and Anderson, 1989; Marshall and Middleton, 1990; Middleton et al., 1991; Wadleigh and Veizer, 1992). In addition, marine carbonate oxygen isotope studies suggest a significant positive shift in $\delta^{18} \mathrm{O}$ of about $2 \%$ during the Devonian-Carboniferous transition (Popp et al., 1986a; Veizer et al., 1986; Brand, 1989b; Lohmann and Walker, 1989; Carpenter et al., 1991). Major increases in $\delta^{18} \mathrm{O}$ also occurred in the Oligocene (Hudson and Anderson, 1989; Railsback, 1990). All these positive $\delta^{18} \mathrm{O}$ excursions can be linked to the onset of global cooling (Stanley, 1988, pp. 341; Railsback, 1990; Wadleigh and Veizer, 1992; Joachimski et al., 2006), combining temperature, ice storage and $\mathrm{pH}$ effects on carbonate $\delta^{18} \mathrm{O}$. Such excursions are superimposed on a long-term trend of increasing $\delta^{18} \mathrm{O}$ through the Phanerozoic, which has been interpreted to reflect increasing seawater ${ }^{18} \mathrm{O} /{ }^{16} \mathrm{O}$ (Veizer et al., 2000).

With the exception of continental glaciation, only major shifts in water cycling between seawater and the lithosphere can possibly induce a change in seawater $\delta^{18} \mathrm{O}$ (Qing and Veizer, 1994). Five geological processes are thought capable of affecting the $\delta^{18} \mathrm{O}$ balance of the oceans in this way: continental weathering; submarine clay diagenesis; high- and low-temperature hydrothermal 
alteration; and tectonic recycling (Muehlenbachs, 1998). Numerous models have been constructed to resolve the controversy of the carbonate $\delta^{18} \mathrm{O}$ trend (Muehlenbachs and Clayton, 1976; Gregory and Taylor, 1981; JeanBaptiste et al., 1997; Muehlenbachs, 1998; Lécuyer and Allemand, 1999; Wallmann, 2001, 2004), concentrating largely on the Phanerozoic, but none have succeeded in resolving the issue. By contrast, seawater $\delta^{18} \mathrm{O}$ evolution during the Precambrian has received very little attention.

Most seawater $\delta^{18} \mathrm{O}$ modelling is based solely on estimated ${ }^{18} \mathrm{O}$-fluxes due to continental and submarine weathering, hydrothermal alteration and tectonic processes (Holland, 1984, pp. 248; Gregory, 1991), the most important of which is perceived to be hydrothermal cycling. Only few of these modelling studies have incorporated large datasets spanning more than a few 100 million years to evaluate the significance of the carbonate $\delta^{18} \mathrm{O}$ trend. In addition, no modelling studies have actively sought to reconcile the discrepancy between the clear temporal trend displayed in marine carbonates and the lack of such a trend in ophiolite rocks (e.g. Muehlenbachs, 1998).

In this review we seek to address some of these shortfalls by:

1) Reviewing the relative potential for preservation of primary marine $\delta^{18} \mathrm{O}$ trends in skeletal apatite, skeletal calcite, chert and bulk carbonate rock samples;

2) Presenting an updated compilation of marine carbonate $\delta^{18} \mathrm{O}$ data covering the entire marine sedimentary record;

3) Assessing the statistical and geological significance of this compilation and of any secular trends that arise from it;

4) Reviewing published interpretations of the potential causes of the long-term trend of increasing marine carbonate $\delta^{18} \mathrm{O}$, exploring in particular the likelihood that this trend reflects changing seawater $\delta^{18} \mathrm{O}$;

5) Developing further an existing model to establish the major controls on seawater $\delta^{18} \mathrm{O}$ to determine whether changing seawater $\delta^{18} \mathrm{O}$ can be reconciled with the apparently unchanging ophiolite $\mathrm{O}$-isotope record;

6) Identifying the most likely reasons for increasing seawater $\delta^{18} \mathrm{O}$ and exploring its implications for Earth System evolution.

\section{The paleoseawater $\delta^{18} \mathrm{O}$ archive}

Carbonate $\delta^{18} \mathrm{O}$ studies have been carried out on a wide range of marine authigenic materials (skeletal calcite, e.g. calcitic brachiopods, belemnites, foraminifera; skeletal apatite, e.g. fish bones, conodonts, phos- phatic brachiopods; chert; and dolomite and calcite in the form of cements, micrite and bulk rock samples; $\mathrm{cf}$. Fig. 1), each of which is discussed individually below.

\subsection{Skeletal calcite}

\subsubsection{Brachiopods}

Fossil brachiopods are a commonly used material for tracing paleo-ocean chemistry from the Middle Cambrian to the Recent (Al-Aasm and Veizer, 1982; Popp et al., 1986a,b; Veizer et al., 1986; Brand, 1989a,b; Wadleigh and Veizer, 1992; Qing and Veizer, 1994). Modern brachiopods are found in all climatic zones where $30{ }^{\circ} \mathrm{C}$ is not exceeded (Veizer et al., 1986; Brand et al., 2003). Inarticulate brachiopods live primarily in subtropical-tropical settings while articulates are located more in temperate regions (Rudwick, 1970, pp. 159). The optimal habitats for ancient brachiopods are likely to have been similar (Veizer et al., 1986) although their depth range is believed to have become shallower since the beginning of the Mesozoic era (Brand et al., 2003).

Brachiopod shells are abundant in Ordovician to Recent marine sediments (Lowenstam, 1961; Wadleigh and Veizer, 1992) and their physiology has presumably not changed since at least the mid-Carboniferous or late Mississippian (Lowenstam, 1961). It is generally accepted that articulate brachiopods secrete their stable low-Mg calcite (LMC: $<4$ mol.\% $\mathrm{MgCO}_{3}$; Veizer, 1983; James and Choquette, 1990b) shells in equilibrium with ambient seawater isotopic composition (Lowenstam, 1961, pp. 257; Veizer et al., 1986; Popp et al., 1986a; Brand, 1989a,b; Grossman et al., 1991; Wadleigh and Veizer, 1992; Qing and Veizer, 1994; Veizer et al., 1997; Wenzel et al., 2000; Brand, 2004). However, an experimental study by Carpenter and Lohmann (1995) indicated that $\delta^{18} \mathrm{O}$ values can vary by up to about $\pm 1 \%$ 。

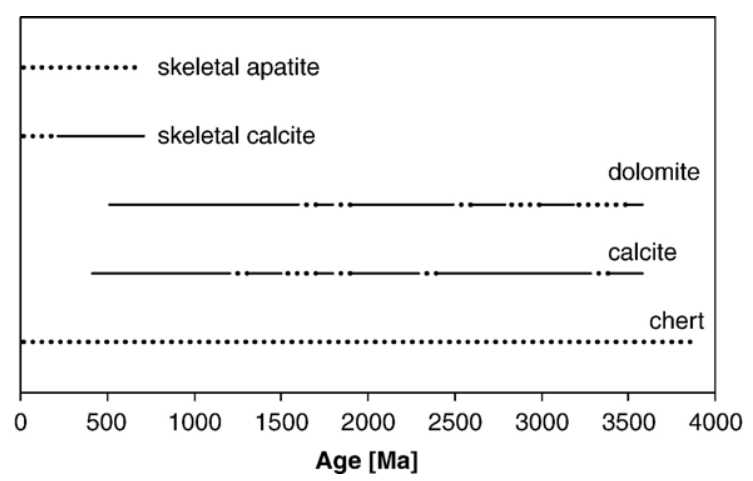

Fig. 1. Age distribution of published marine oxygen isotope data. Potentially available data that are not included in the compilation are shown by dotted lines. 
within single brachiopod shells and, thus, brachiopods may not always be precise recorders of paleoceanographic isotopic composition. Oxygen isotopic differences among coeval taxa can be triggered by metabolic effects (vital effect) or seasonality in growth (Grossman et al., 1991). Additional problems are that $\delta^{18} \mathrm{O}$ values from brachiopod samples may reflect superimposed vital fractionation effects, and/or be altered after deposition (cf. Qing and Veizer, 1994). Recrystallisation of the shell calcite after deposition generally leads to lower $\delta^{18} \mathrm{O}$ values (Veizer et al., 1986).

The shells of articulate brachiopods are normally composed of low-Mg calcite while some inarticulate forms have a phosphatic shell (Veizer et al., 1997). Low$\mathrm{Mg}$ calcite, articulate brachiopod shells are believed to be among the most resistant forms of marine carbonate to diagenetic alteration and, thus, seem the most likely to preserve a primary $\delta^{18} \mathrm{O}$ signature (Popp et al., 1986a; Grossman et al., 1991; Marshall, 1992; Veizer et al., 1997; Brand and Brenckle, 2001; Samtleben et al., 2001; Brand, 2004). Inarticulate phosphatic brachiopods, on the other hand, have not found favour as proxies of primary marine $\delta^{18} \mathrm{O}$, since relatively low isotopic compositions in inarticulate brachiopods can best be ascribed to post-depositional alteration of the biogenic phosphate (Wenzel et al., 2000).

Previous studies indicate that the exterior or primary layer of brachiopod shells is most susceptible to postdepositional alteration, while the volumetrically dominant, interior secondary layer will generally retain its primary isotopic composition (Grossman et al., 1991; Qing and Veizer, 1994; Carpenter and Lohmann, 1995). Accordingly, cathodoluminescence, an indicator of diagenetic alteration (see later discussion in Section 4.1), is mostly confined to the exterior primary layer of brachiopods (Veizer et al., 1997). To determine the extent of post-depositional alteration, the abundances of particular trace elements such as $\mathrm{Mn}, \mathrm{Fe}$ and $\mathrm{Sr}$ are generally measured (Wadleigh and Veizer, 1992). While recrystallisation leads to enrichment in $\mathrm{Mn}$ and $\mathrm{Fe}, \mathrm{Sr}$ is preferentially excluded from the low-Mg calcite end product (Veizer, 1983; Wadleigh and Veizer, 1992). The characteristics of the interior, secondary layer of ancient brachiopod shells, as analysed using scanning electron microscopy, commonly shows no signs of recrystallisation, thus appearing very similar to those of their modern counterparts, indicating that a significant proportion of brachiopod shells are well preserved throughout the Phanerozoic (Veizer et al., 1997). Microtextural and trace element data represent strong arguments to support the pristine nature of the observed trend of increasing marine carbonate $\delta^{18} \mathrm{O}$ since the Cambrian period
(Veizer et al., 1997, 1999, 2000; Shields et al., 2003). When this trend is removed from the dataset of all published Phanerozoic brachiopod $\delta^{18} \mathrm{O}$ data, the remaining fluctuations coincide with known greenhouse-icehouse cycles of the Phanerozoic (Veizer et al., 2000), thus appearing to confirm its significance.

\subsubsection{Belemnites}

By analogy to modern Sepia cuttlebones, belemnite shells are believed to have precipitated in isotopic equilibrium with seawater (Urey et al., 1951; Longinelli et al., 2003). The relatively compact shell structure and low-Mg calcite mineralogy of belemnites appears to make them fairly resistant to later alteration and recrystallisation (Longinelli et al., 2002; Brand, 2004). On the other hand, belemnite rostra may be rather porous (3-10\%, Veizer, 1974) and this porosity may be filled by secondary calcite, leading to slight alteration of the isotopic signal of belemnites (Veizer, 1974; Veizer and Fritz, 1976; Veizer et al., 1997). These fossil groups are specifically important for the Mesozoic only (cf. Veizer et al., 1997), for which time seawater $\delta^{18} \mathrm{O}$ is not considered to have deviated significantly from that of more recent times (Veizer and Hoefs, 1976; Van de Schootbrugge et al., 2000).

\subsubsection{Foraminifera}

Similarly to brachiopods and belemnites, $\delta^{18} \mathrm{O}$ of foraminiferal calcite is primarily influenced by the temperature and isotopic composition of the water in which the shell grew (Waelbroeck et al., 2005). Since planktonic foraminifera live at different depths in the upper water column, the $\delta^{18} \mathrm{O}$ difference between certain species can be used as a tracer of temperature and density stratification (Williams and Healy-Williams, 1980; Mulitza et al., 1997; Mortyn and Charles, 2003). Because thermohaline ocean stratification may vary seasonally, the $\delta^{18} \mathrm{O}$ values of fossil and living foraminifera may range widely depending on oceanographic conditions, seriously complicating the use of foraminifera for paleoceanographic reconstruction (Waelbroeck et al., 2005).

The size and age of foraminifera have an influence on shell $\delta^{18} \mathrm{O}$ (Waelbroeck et al., 2005). The extent of this effect seems to depend on the species and local effects (Waelbroeck et al., 2005). Model simulations (WolfGladrow et al., 1999) and fossil studies (cf. McConnaughey, 1989) indicate that variations in respiration, calcification rate and symbiont photosynthesis can all result in substantial modifications of $\mathrm{pH}$ in the vicinity of the foraminiferal shell and therefore can result in significant $\delta^{18} \mathrm{O}$ variability (Spero et al., 1997). Although foraminifera are used extensively for reconstructing 
paleotemperatures and in particular glacial-interglacial climate fluctuations, foraminiferal isotope data are only relevant since the mid-Mesozoic, for which time estimates of seawater paleotemperature assuming modern day seawater $\delta^{18} \mathrm{O}$ coincide with independent estimates. Therefore, foraminifera, as with belemnites, do not play any role in the long-standing controversy over the oxygen isotope evolution of seawater.

\subsection{Skeletal apatite}

$\delta^{18} \mathrm{O}$ of skeletal phosphate is considered by some authors to be an attractive tool for paleoclimatological reconstruction (Blake et al., 1997) because mineral phosphate is less susceptible to late diagenetic dissolution than carbonate materials (Longinelli et al., 2003). Nevertheless, skeletal phosphate may undergo alteration during weathering and early diagenesis (McArthur, 1985; McArthur et al., 1987; Ayliffe et al., 1992; Sharp et al., 2000), while $\delta^{18} \mathrm{O}$ values can be significantly altered when recrystallisation is accompanied by microbially mediated $\mathrm{PO}_{4}^{3-}$ degradation (Blake et al., 1997; Wenzel et al., 2000), diagenetic apatite recrystallisation (Kolodny et al., 1996), or complete dissolution at high diagenetic temperatures (Blake et al., 1997; Lécuyer et al., 1999).

Several studies indicate that the oxygen isotope compositions of fish bones and fish teeth can be useful indicators of marine paleotemperatures throughout the Mesozoic and Cenozoic, since they appear not to exhibit any vital effects (Kolodny et al., 1983; Kolodny and Luz, 1991; Lécuyer et al., 1993; Anderson et al., 1994; Fricke et al., 1998; Lécuyer and Allemand, 1999). It should be noted, however, that the $\delta^{18} \mathrm{O}$ of biogenic apatite needs to be carefully evaluated because all samples will have undergone diagenetic recrystallisation due to the thermodynamically metastable nature of skeletal phosphate minerals (Grandjean et al., 1987; Kolodny and Raab, 1988; Kohn et al., 1999; Sharp et al., 2000). Because skeletal apatite (porous carbonate hydroxyapatite) always undergoes recrystallisation to francolite (carbonate fluorapatite) during early diagenesis (Kolodny et al., 1996), analysis of microstructures and trace element concentrations of apatites may be only of limited help in assessing the preservation of primary biogenic phosphate $\delta^{18} \mathrm{O}$ values (Wenzel et al., 2000).

Anomalously high $\delta^{18} \mathrm{O}$ values were obtained in several phosphate studies from around the globe and from different stratigraphic positions (Longinelli and Nuti, 1968b; Longinelli et al., 2002, 2003). These results were explained as either being caused by diagenesis or higher paleo-seawater $\delta^{18} \mathrm{O}$ using the assumption that marine inorganic phosphate precipitated under conditions of isotopic equilibrium (Longinelli and Nuti, 1968a; Longinelli et al., 2002). Because no widespread diagenetic process is known that results in the ${ }^{18} \mathrm{O}$ enrichment of phosphate, these values have been interpreted to indicate that the ${ }^{18} \mathrm{O} /{ }^{16} \mathrm{O}$ ratio of seawater decreased subtlely from the Jurassic Period to recent times (Longinelli et al., 2002). The massive precipitation in the form of pelagic oozes of deep marine limestones enriched by about $30 \%$ in ${ }^{18} \mathrm{O}$ with respect to seawater was offered as a partial explanation for the fall in apatite $\delta^{18} \mathrm{O}$ since the Jurassic Period (Longinelli et al., 2003). This large sink of heavy oxygen could potentially deplete ocean water in ${ }^{18} \mathrm{O}$ through time because the oxygen in deep marine carbonates will be recycled by weathering and metamorphism at a slower rate than their shallow marine counterparts. The possible extent of this effect remains to be quantified, while the ultimate dependence of marine carbonate deposition rates on volcanic and metamorphic outgassing rates (Walker et al., 1981) as well as on the dissolution rates of carbonate minerals on land suggests that this must be a minor, and relatively short-lived effect at best.

In the case of belemnite phosphate studies, the low phosphate content of their rostra generally does not allow the determination of their mineralogical composition and so it is difficult to exclude the possibility that samples were contaminated during early diagenetic organic decay (Longinelli et al., 2002, 2003). If the phosphate of belemnite organic matter was isotopically heavy as occurs nowadays in the flesh of molluscs, its incorporation into belemnites could be responsible for the elevated $\delta^{18} \mathrm{O}_{\text {phosphate }}$ values exhibited by some belemnites of the Mesozoic era (Longinelli et al., 2003). The elevated $\delta^{18} \mathrm{O}_{\text {phosphate }}$ composition of belemnites could also be explained if belemnites lived mostly in the deep ocean, approaching shallow waters only during the very last stages of their life (Longinelli et al., 2002, 2003).

Wenzel et al. (2000) found in their study that Silurian conodont samples underwent less post-depositional oxygen isotope exchange than coeval inarticulate brachiopod shell apatite based on the wider range of $\delta^{18} \mathrm{O}$ in the phosphatic inarticulates. This relative difference supports previous comparative studies that demonstrate pervasive geochemical alteration of skeletal apatite (e.g. Ebneth et al., 2001).

\subsection{Chert}

Chert is a chemically precipitated sedimentary rock primarily composed of microcrystalline and/or chalcedonic quartz, minor megaquartz and impurities (Folk, 
1980, pp. 80; Perry and Lefticariu, 2003). Much Precambrian chert was derived from abiogenic precipitation in peritidal and shallow marine shelf environments whereas modern chert is mainly recrystallised from biogenic, skeletal silica in deep ocean sediments and in slope areas of very high productivity since the widespread appearance of radiolaria and diatoms in the Phanerozoic (Perry and Lefticariu, 2003). Biogenic (e.g. diatoms) siliceous sediments are converted from relatively soluble opal-A to opal-CT over a period of $10^{3}-10^{7}$ years, and finally to crystalline chert (Siever, 1992; Bohrmann et al., 1994; Knauth, 1994; Perry and Lefticariu, 2003).

Chert displays a high resistance towards dissolution and recrystallisation, which may occur during metamorphic processes (Knauth, 2005). Because such processes may involve low water/rock ratios, the $\delta^{18} \mathrm{O}$ values of chert are not necessarily affected (Knauth and Lowe, 2003; Knauth, 2005). Thus, the $\delta^{18} \mathrm{O}$ values of Precambrian chert have been used to trace shallow ocean paleotemperatures where it was regarded that chert stabilisation occurred during shallow burial (Knauth, 2005). The $\delta^{18} \mathrm{O}$ fractionation of chert is temperature dependent and follows the equation $1000 * \ln \left(\alpha_{\text {chert-water }}\right)=$
$3.09 * 10^{6} \mathrm{~T}^{-2}-3.29(\alpha=$ oxygen isotope fractionation factor; Knauth and Epstein, 1976).

It has long been noted that early Precambrian cherts yield anomalously low $\delta^{18} \mathrm{O}_{\text {SMOW }}$ values compared with today (Fig. 2). This has been interpreted in terms of higher ocean temperatures of $75^{\circ} \mathrm{C}$ or more during the Archean (Knauth and Epstein, 1976; Knauth and Lowe, 1978; Karhu and Epstein, 1986; Knauth and Lowe, 2003). Most of these data derived from the circa $3.4 \mathrm{Ga}$ Onvervacht Group of the Barberton greenstone belt, South Africa, while coverage through the rest of the Precambrian was, and still is, sparse (Perry and Lefticariu, 2003; Robert and Chaussidon, 2006). Recent data (Knauth and Lowe, 2003) from the Swaziland Supergroup are consistent with previous results (Perry, 1967; Knauth and Lowe, 1978), in that the highest $\delta^{18} \mathrm{O}$ value found in these cherts $\left(+22 \%{ }_{\text {SMOW }}\right)$ is about $8 \%$ lower than the lowest values of "representative" shallow marine cherts of the Devonian, while Barberton Belt cherts are on average depleted in ${ }^{18} \mathrm{O}$ by about $10 \%$ compared with recent cherts (Perry and Lefticariu, 2003). By comparison, metacherts of the circa $3.8 \mathrm{Ga}$ Isua supracrustal belt show even lower maximal $\delta^{18} \mathrm{O}$ values, of $+20 \%$ smow (Perry et al., 1978) and are at

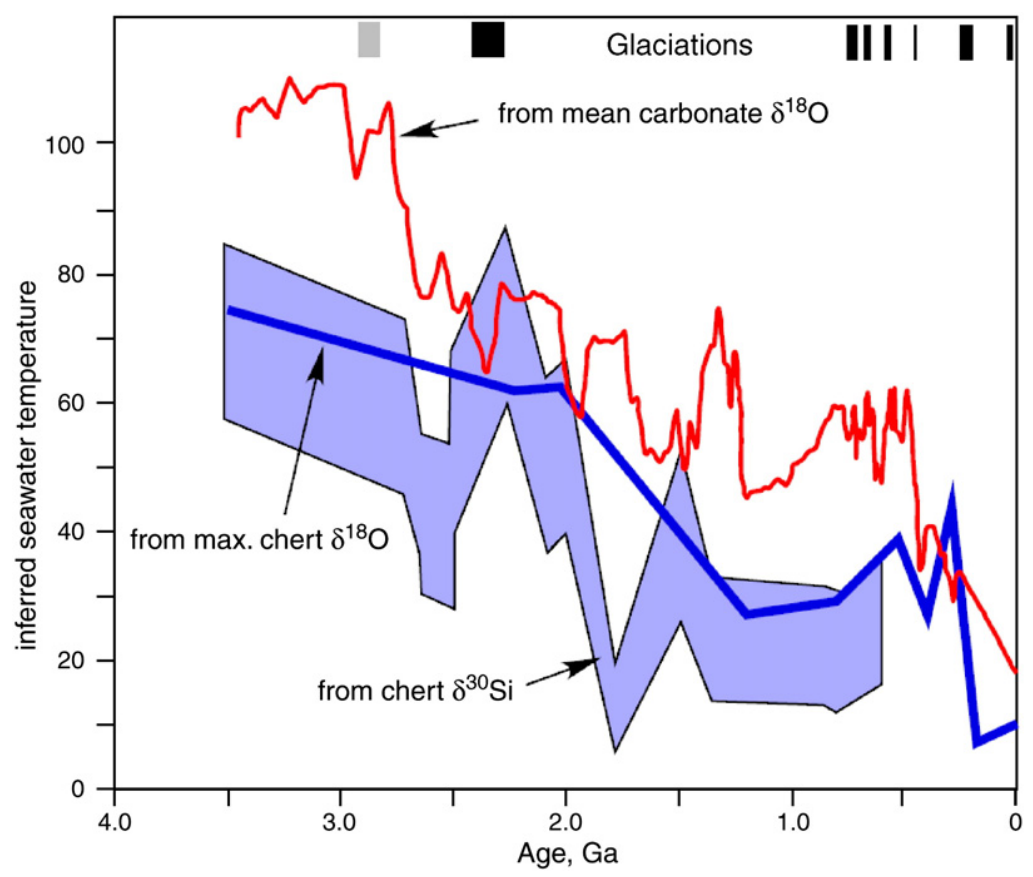

Fig. 2. Implausibly high paleotemperature estimates based on the assumptions that seawater $\delta^{18} \mathrm{O}$ has remained unchanged throughout Earth history and that all samples provide faithful records of open marine isotopic composition. The maximum chert $\delta^{18} \mathrm{O}$ line represents minimum ocean temperature and is from data in Knauth and Lowe (1978) and Robert and Chaussidon (2006); mean carbonate $\delta^{18} \mathrm{O}$ line is from data compiled for this paper. $\delta^{30} \mathrm{Si}$ constraints are from Robert and Chaussidon (2006). The film strip is displaying glacial episodes (black: confirmed cool periods; grey: possible glaciation at $2.9 \mathrm{Ga}$ ). 
higher metamorphic grade than their Barberton (and Pilbara) counterparts. If seawater $\delta^{18} \mathrm{O}$ during the early-mid Archean was comparable to today (Muehlenbachs, 1998), and these maximal $\delta^{18} \mathrm{O}$ values represent an open marine isotopic signature, then such low $\delta^{18} \mathrm{O}$ implies that early oceans were hot, with ambient temperatures of between $55^{\circ} \mathrm{C}$ and $90{ }^{\circ} \mathrm{C}$ (Perry and Lefticariu, 2003).

Additional support for hot early oceans has come from a silicon isotope study of marine cherts (Fig. 2). In their study, Robert and Chaussidon (2006) report a positive correlation between $\delta^{18} \mathrm{O}$ and $\delta^{30} \mathrm{Si}$ in Precambrian cherts. Unlike $\delta^{18} \mathrm{O}, \delta^{30} \mathrm{Si}$ values in silica do not so much depend on temperature as on the isotopic composition of the medium from which the chert precipitated. The authors argue that seawater $\delta^{30} \mathrm{Si}$ is controlled by the difference between the temperature of the oceans and that of hydrothermal fluids. The observed trend towards higher $\delta^{30} \mathrm{Si}$ values between $3.5 \mathrm{Ga}$ and $0.8 \mathrm{Ga}$ could therefore be interpreted as reflecting a progressive decrease in ocean temperature of approximately the same magnitude as that discerned from the chert $\delta^{18} \mathrm{O}$ record. Conversely, this correlation could instead reflect a progressive increase in the globally integrated mean temperature of hydrothermal alteration (Kasting et al., 2006; Shields and Kasting, 2007), in which case low chert $\delta^{18} \mathrm{O}$ values could equally reflect lower seawater $\delta^{18} \mathrm{O}$.

The use of cherts to reconstruct past ocean temperature is controversial as the open marine environment of formation of many Precambrian cherts has been questioned (De Wit et al., 1982; Perry and Lefticariu, 2003). In this regard, it may not be meaningful to compare directly the isotopic compositions of 1) greenstone-associated early diagenetic cherts of the early and middle Archean, some of which have been interpreted to be of replacive, hydrothermal origin (e.g. Van Kranendonk, 2006), 2) iron formation-associated early diagenetic chert bands formed between 2.5 and $1.8 \mathrm{Ga}$, or 3) peritidal, evaporite-associated cherts of the Meso- and Neoproterozoic, with predominantly biomediated pelagic cherts of the Phanerozoic. Despite such reservations, the general 10\% depletion of Archean cherts is mirrored by an equivalent isotopic depletion in contemporaneous and most later Precambrian marine carbonates (Shields and Veizer, 2002), suggesting that neither later alteration nor restricted settings was the primary factor controlling the controversial $\delta^{18} \mathrm{O}$ trend (Kasting and Ueno, 2006).

As with the chert record, ancient marine carbonates are known to be anomalously depleted with respect to their more recent counterparts; however, the $\delta^{18} \mathrm{O}$ trends of these two mineral groups are quite different (Fig. 2).
In the carbonate record, low $\delta^{18} \mathrm{O}$ values are found throughout the period before $450 \mathrm{Ma}$ (Shields and Veizer, 2002), while the chert record shows modern daylike $\delta^{18} \mathrm{O}$ and $\delta^{30} \mathrm{Si}$ values already during the Mesoproterozoic (Knauth and Lowe, 1978), and Paleoproterozoic (Robert and Chaussidon, 2006). The chert $\delta^{18} \mathrm{O}$ debate is in many ways indistinguishable from the parallel debate over the marine carbonate $\mathrm{O}$-isotope record but is complicated by the clear transition that occurred in the depositional setting of marine chert across the Proterozoic-Phanerozoic transition from shallow to deep marine environments. For more detail on the chert $\delta^{18} \mathrm{O}$ record, the interested reader is referred to the authoritative review of Perry and Lefticariu (2003).

\subsection{Skeletal calcite vs skeletal apatite}

Direct comparisons between skeletal calcite and apatite O-isotope records can be made for the controversial Paleozoic era of anomalously low $\delta^{18} \mathrm{O}$ values by comparing brachiopod and conodont data, respectively. Conodonts (euconodonts) first appeared around 492 Ma (Smith et al., 2001). These tooth-like jaw components of an extinct marine chordate animal are composed of carbonate fluorapatite (francolite; cf. Wenzel et al., 2000). Phosphate $\delta^{18} \mathrm{O}$ of conodonts, fish teeth and other marine biogenic apatites should be relatively resilient against diagenetic alteration (Wenzel et al., 2000). However, conodonts have been shown not to record a primary seawater composition as faithfully as low-Mg calcite brachiopods for several parameters, e.g. Sr isotopes (Diener et al., 1996; Brand, 2004) and rare earth element distribution patterns (Shields and Webb, 2004). Diagenetic alteration even at low intensity (based on the CIA or Conodont Index of Alteration) can change the original geochemical signatures of these materials (Diener et al., 1996; Veizer et al., 1997).

Lécuyer and Allemand (1999) found that the $\delta^{18} \mathrm{O}$ values of brachiopods tend to be systematically higher than those of skeletal apatite from fish and conodonts. This was considered to be caused by their different living environments, whereby brachiopod $\delta^{18} \mathrm{O}$ reflects bottom water temperatures, while nektonic and pelagic faunas reflect the generally warmer conditions of the overlying surface or intermediate waters (Lécuyer and Allemand, 1999). Similar interpretations have been made to explain the systematic difference between belemnites and bulk carbonate rock (largely derived from skeletal plankton) from the Cretaceous period (Van de Schootbrugge et al., 2000).

Wenzel et al. (2000) considered in their study that the paleotemperature and $\delta^{18} \mathrm{O}$ of Silurian seawater are 
more accurately reflected in conodonts than coeval calcitic brachiopod shells because the $\delta^{18} \mathrm{O}$ values of their Silurian conodonts were modern-like, while most Silurian calcitic brachiopod shells are depleted in ${ }^{18} \mathrm{O}$ when compared to modern or Mesozoic brachiopods. The discrepancy in $\delta^{18} \mathrm{O}$ was explained as being the result of diagenetic alteration of shell calcite (Wenzel et al., 2000). However, the difference in $\delta^{18} \mathrm{O}$ between phosphatic and calcitic elements could also indicate that they formed or underwent alteration in different environments, implying that conodont animals lived in cooler, presumably deeper waters than bottom-dwelling brachiopods or that conodonts underwent alteration beneath cooler bottom waters.

Within the same unaltered carbonate shell, the $\delta^{18} \mathrm{O}$ value is expected to be higher for carbonate (by about $+8.5 \%$ ) than for phosphate (Longinelli and Nuti, 1973: Fig. 2; Iacumin et al., 1996: Fig. 2). Therefore, the difference between phosphate and carbonate $\delta^{18} \mathrm{O}$ could potentially be used to determine whether or not the shells were affected by post-depositional alteration (Iacumin et al., 1996).

\subsection{Bulk skeletal vs abiotic calcite}

A major problem with tracing the marine $\delta^{18} \mathrm{O}$ record back into the Precambrian is that the carbonate archive changes from skeletal material to bulk carbonate or, in some cases, to selected calcitic components, such as early marine cements or micrite. Articulate brachiopods are generally considered the most suitable proxy to evaluate paleotemperatures and the evolution of seawater $\delta^{18} \mathrm{O}$ (Veizer et al., 1997; Brand, 2004) because they secrete stable low-Mg calcite, while bulk carbonates (limestone and dolomite) may derive from metastable aragonite or high-Mg calcite and so can undergo considerable alteration during diagenetic changes in mineralogy (Veizer et al., 1997). The post-depositional alteration of limestone and dolomite precursors generally leads to lower $\delta^{18} \mathrm{O}$ (Veizer et al., 1997); however, because isotopic exchange generally occurs early in the rock's history, limestone and dolomite alteration will commonly take place under near-marine conditions, albeit $\delta^{18} \mathrm{O}$ may be shifted towards slightly lower values (Veizer et al., 1999). The difference between bulk rock and skeletal calcite (brachiopods, foraminifera) amounts on average to about 2-3\% (Schrag et al., 1995: Fig. 4; Veizer et al., 1999: Fig. 20).

The extent of preservation of original seawater chemistry in bulk rocks can be evaluated using luminescence, trace element chemistry and texture evaluation (Brand, 2004). Fine-grained bulk carbonate (micrite) has not experienced obvious recrystallisation and is therefore considered likely to have retained an original nearseawater composition (Brand, 2004). Because of the tendency for bulk carbonate $\delta^{18} \mathrm{O}$ to decrease during diagenesis, high $\delta^{18} \mathrm{O}$ values are generally considered to reflect a more pristine, or primary isotopic composition. However, this is only a rule-of-thumb as bulk carbonate may sometimes exhibit higher values than coeval, apparently well-preserved skeletal remains because of their different environments of formation (Van de Schootbrugge et al., 2000; Korte et al., 2005a,b).

Positive stable isotope excursions of the Neoproterozoic and Palaeozoic eras are commonly associated with global cooling. In the case of the short-lived Late

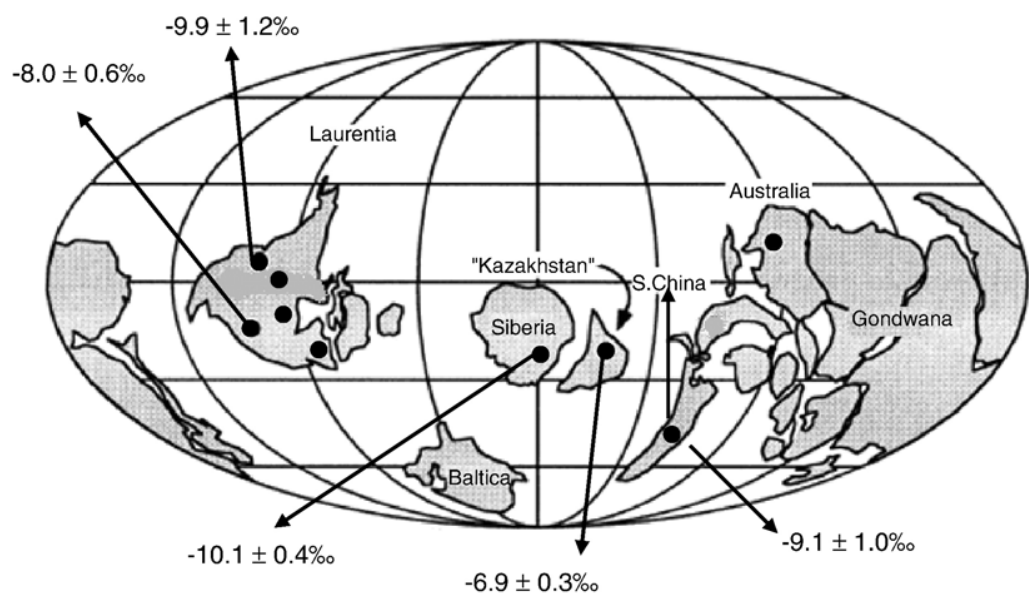

Fig. 3. Paleogeographic map for the Late Cambrian showing approximate locations of the regions from where the Steptoean positive isotope carbon excursion (SPICE) has been reported (Saltzman et al., 2000). The mean values and corresponding standard deviations of $\delta^{18} \mathrm{O}$ studies derive from data in Glumac and Walker (1998), Saltzman et al. (1998, 2000) and Shields and Veizer (2002). 
Ordovician O-isotope excursion, the onset of global cooling and glaciation is clearly recorded in both brachiopods and bulk carbonate rock with $\delta^{18} \mathrm{O}$ distinctly higher than the background values of the rest of the Ordovician and Silurian periods (Marshall and Middleton, 1990; Middleton et al., 1991; Qing and Veizer, 1994; Marshall et al., 1997; Azmy et al., 1998; Kump et al., 1999; Shields et al., 2003; Brenchley et al., 2003). Another example of O-isotope fidelity in bulk carbonates is provided by the Late Cambrian Steptoean positive isotope carbon excursion (SPICE). Although characterised also by a global, positive $\delta^{13} \mathrm{C}$ excursion of similar magnitude, there is no geochemical or geological evidence for the build-up of glaciers during the Late Cambrian (Saltzman et al., 2004). Because of this global $\delta^{13} \mathrm{C}$ signal, O-isotope data from around the world can be compared from exactly the same stratigraphic interval at c. $497.5 \mathrm{Ma}-495 \mathrm{Ma}$ (Fig. 3). $\delta^{18} \mathrm{O}$ shows no significant variation over this same time interval and exhibits systematically low values in all datasets (Glumac and Walker, 1998; Saltzman et al.,
$1998,2000,2004)$ that are indistinguishable (both datasets average $-8.9 \%$, while ranging up to $-6 \%$ ) from microtexturally-controlled brachiopod data of the Early and Middle Ordovician (Shields et al., 2003). The spread in mean values of $3.2 \%$ between individual studies is well within that of the modern ocean. Oisotope depletion, relative to today, is therefore evident in both the skeletal calcite and the bulk carbonate archives to a similar extent during the interval where these two data groups overlap, although it is generally acknowledged that bulk carbonate data tend in some cases to show more scatter and may be slightly offset to lower values (Veizer et al., 1999).

As well as micrite, generations of marine cements can be recognised in limestones and dolostones and targeted specifically for analysis, thus allowing the effects of diagenetic alteration to be backtracked (e.g. Tobin and Walker, 1996). From such studies it has been established that translucent fibrous cement from the Ordovician to the Holocene is typically less altered than turbid fibrous cement (Tobin and Bergstrom, 2002). In
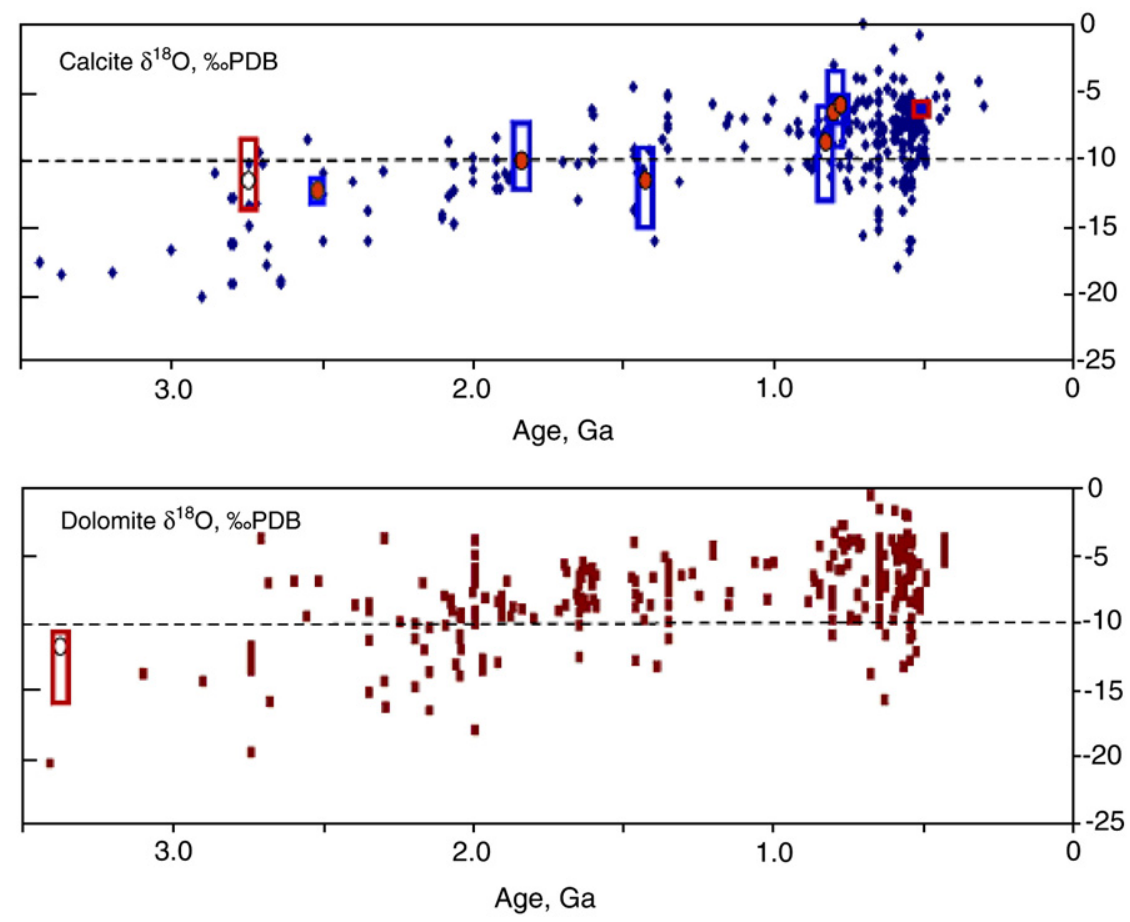

Fig. 4. Marine limestone and dolostone $\delta^{18} \mathrm{O}$ plotted as mean values of data from stratigraphic units with sample size $>2$ (from data compiled for this paper). 272 sample sets characterised as clearly altered or from clearly evaporitic settings have been removed from a total of 808 . Boxes with filled circles refer to the range and mean $\delta^{18} \mathrm{O}$ values, respectively, of early marine, originally low-Mg-calcite cements (Johnson and Goldstein, 1993; Bishop et al., 2006; Shields, unpubl. data); open circles are from representative isotopic studies of Archean carbonate rocks (Abell et al., 1985; Lindsay et al., 2005). With the exception of intervals of cool climate, calcites and dolomites of the Precambrian and early Phanerozoic are up to 5$10 \%$ depleted in ${ }^{18} \mathrm{O}$ with respect to later Phanerozoic and modern equivalents (Veizer et al., 1999; Shields and Veizer, 2002; Shields et al., 2003). The persistence of low $\delta^{18} \mathrm{O}$ into the early Ordovician implies however that changing seawater ${ }^{18} \mathrm{O} /{ }^{16} \mathrm{O}$ and not temperature is likely to have been the major controlling factor over this trend (cf. Fig. 2). 
some cases, demonstrably early calcite cements exhibit higher, and presumably more primary $\delta^{18} \mathrm{O}$ values than the surrounding bulk rock matrix, although bulk micrite, brachiopods and cements provide parallel trends (Tobin and Bergstrom, 2002). Johnson and Goldstein (1993) published $\delta^{18} \mathrm{O}$ data from low-Mg calcite, early marine cements of the latest Cambrian that approach the highest $\delta^{18} \mathrm{O}$ values found from micrite and brachiopod studies of roughly contemporaneous samples around the world. These $\delta^{18} \mathrm{O}$ values, averaging $-6 \%$, are also similar in magnitude to early marine calcite $\delta^{18} \mathrm{O}$ data from the Neoproterozoic (Fig. 4).

In the Proterozoic, early marine cements are commonly composed of microcrystalline low-Mg calcite, which often shows signs of soft-sediment deformation, early lithification and resistance to early dolomitisation, indicative of an unusually early marine origin (e.g. Shields, 2002). All published and unpublished molar- tooth microcrystalline calcite $\delta^{18} \mathrm{O}$ data known to the authors is shown in Fig. 4. Unlike with Phanerozoic early marine cements, there appears to be no apparent difference in $\delta^{18} \mathrm{O}$ between Proterozoic microcrystalline calcite and its matrix (Frank and Lyons, 2000), unless the latter has been dolomitised, which may be due to the higher saturation states and hence rapid, early lithification of Proterozoic marine carbonate rocks.

\subsection{Dolostone vs limestone}

Limestone consists of calcite $\left(\mathrm{CaCO}_{3}\right)$ and forms by either biological activity or by inorganic precipitation (Blatt, 1982). Dolomite $\left(\mathrm{CaMg}\left(\mathrm{CO}_{3}\right)_{2}\right)$, which is generally inherited from precursor limestone (Blatt, 1982; Kah, 2000; Eglington et al., 2003), is more commonly found in ancient than modern rocks (Vasconcelos et al., 2005). Dolomitisation is often associated with a

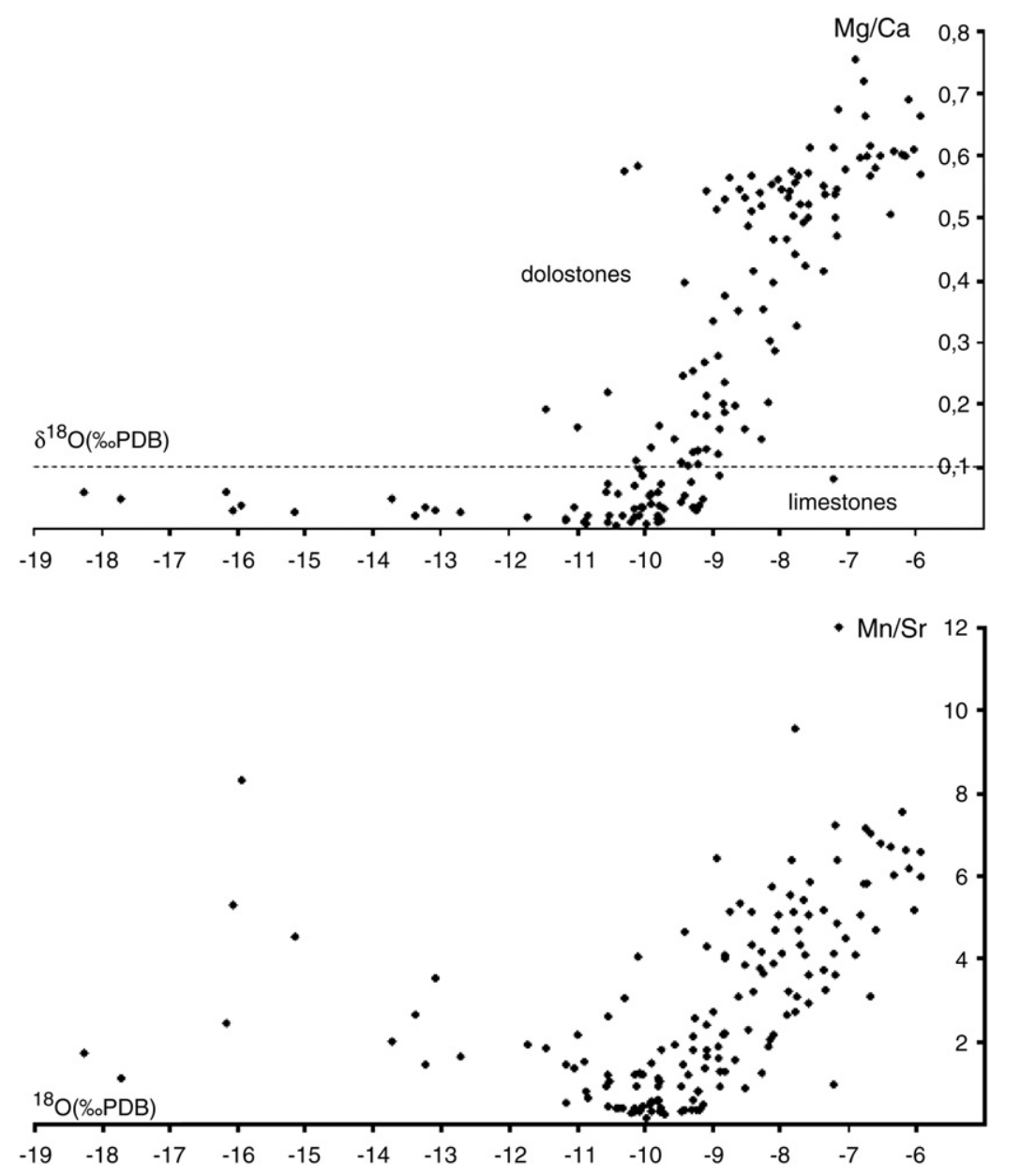

Fig. 5. $\mathrm{Mg} / \mathrm{Ca}$ and $\mathrm{Mn} / \mathrm{Sr}$ against $\delta^{18} \mathrm{O}$ plots showing association of increasing dolomite content, approximated using $\mathrm{Mg} / \mathrm{Ca}$ ratios, with higher $\delta^{18} \mathrm{O}$ and elevated $\mathrm{Mn} / \mathrm{Sr}$ (Kouchinsky et al., unpublished data). Mixed dolomite/calcite samples in this study illustrate the systematic ${ }^{18} \mathrm{O}$-enrichment of dolomite over calcite of around $2-4 \%$. 
hypersaline, evaporative setting as opposed to processes involving freshwater (Friedman, 1980; Blatt, 1982), which can lead to an elevated $\delta^{18} \mathrm{O}$ composition. Dolomite forms when $\mathrm{Mg}$ partially replaces $\mathrm{Ca}$ in calcite (Blatt, 1982). Dolomitisation entails relatively high water-rock ratios to facilitate adequate $\mathrm{Mg}$ supply (Kah, 2000), and, when associated with meteoric or mixedwater diagenesis, should induce a decrease in the $\delta^{18} \mathrm{O}$ value. Early dolomitisation, which is most common (Blatt, 1982), may assist in the retention of primary $\delta^{18} \mathrm{O}$ by reducing pore space and restricting subsequent fluid interaction (cf. Kah et al., 1999).

Dolomite is especially common in the Precambrian rock record where dolomitisation is considered to have been particularly early (Tucker, 1982). Both dolomites and limestones display a trend of decreasing $\delta^{18} \mathrm{O}$ with age, and a similar, shallower slope during the Precambrian (Veizer and Hoefs, 1976; Shields and Veizer, 2002). The average enrichment of dolomite over coeval limestone is 2-4\%o (Veizer and Hoefs, 1976; Land, 1980; Gao, 1993; Kah, 2000), consistent with equilibrium fractionation (Vasconcelos et al., 2005). This systematic enrichment can be confirmed in studies where mixed dolomite/calcite samples from the same section have been analysed for both $\mathrm{Mg} / \mathrm{Ca}$ and $\delta^{18} \mathrm{O}$ (Fig. 5). The temperature dependent $\delta^{18} \mathrm{O}$ fractionation of dolomite is thus defined by $1000 * \ln \left(\alpha_{\text {dolomite-water }}\right)=2.73 * 10^{6} \mathrm{~T}^{-2}+0.26$ (Vasconcelos et al., 2005). Similarly, the equation for calcite was determined as $1000 * \ln \left(\alpha_{\text {calcite-water }}\right)=2.78 * 10^{6} \mathrm{~T}^{-2}-$ 2.89 (Friedman and O’Neil, 1977).

Much of the oldest data in the compilation are from dolomites (e.g. Lindsay et al., 2005; cf. Fig. 6) or less soluble $\mathrm{Mg}, \mathrm{Fe}$ and $\mathrm{Mn}$ carbonate minerals such as magnesite, siderite and rhodochrosite, respectively. The existing early-mid Archean $\delta^{18} \mathrm{O}$ record is unfortunately sparse and is rendered less useful by the frequent absence of mineralogical and petrographic details in publications. Nevertheless, if we consider minimum constraints on pristine marine dolomite $\delta^{18} \mathrm{O}$ from the circa 3.4 Ga Strelley Pool Chert (Lindsay et al., 2005) of about $-11 \%_{\mathrm{PDB}}$ (Fig. 5), it is clear that, even considering a systematic difference between calcite and dolomite of $\sim 2 \%$ (Shields and Veizer, 2002), such values are not considerably depleted with respect to Neoarchean calcite from molar-tooth structure (Fig. 4). Similar values have also been reported for the Barberton greenstone belt of South Africa (Abell et al., 1985; Veizer et al., 1989).

Dolomite commonly forms in restricted settings, giving higher $\delta^{18} \mathrm{O}$ values, and it can be formed during late diagenetic alteration, so it is important to distinguish the dolomite formation mechanism. However, most

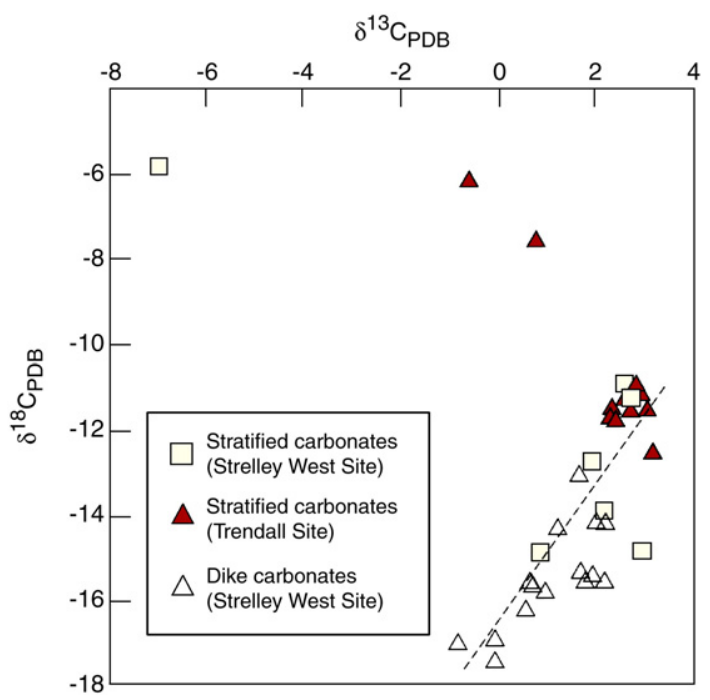

Fig. 6. Crossplot showing stable carbon and oxygen isotopic compositions in \% ${ }_{\mathrm{PDB}}$ of carbonates from the c. $3.4 \mathrm{Ga}$ Strelley Pool Chert at two sites in W. Australia (after Lindsay et al., 2005). Three outlying samples are interpreted to have undergone isotopic exchange during replacement; all other samples show positive correlation that could represent a diagenetic trend, implying that primary carbonate values were close to $+2 /+3 \%$ and $-12 /-11 \%$ for $\delta^{13} \mathrm{C}$ and $\delta^{18} \mathrm{O}$, respectively.

published studies do not distinguish the different generations of dolomite, nor to what extent samples may be mixtures of calcite and dolomite. Such ambiguities mean that dolomite data are less favoured than calcite data for the purposes of interpretation of paleotemperatures and oceanic $\delta^{18} \mathrm{O}$. Most positive outliers in our compilation can be shown to be from dolomites that formed in restricted settings (Kah, 2000; Bau and Alexander, 2006) and so only calcite data were used in the present model. This has little effect on the results herein as both calcite and dolomite samples exhibited identical trends.

\section{The marine carbonate oxygen isotope database}

\subsection{Database update}

The compilation of the present database represents the continuation of work published in Shields and Veizer (2002) and Veizer et al. (1999). The marine origin of oxygen isotope samples (as opposed to, for example, a lacustrine origin) was ascertained from the authors' original interpretations and overall geological setting. Those of likely marine origin were then included in an already existing global oxygen isotope database (cf. Shields and Veizer, 2002: Table 1), totalling 19,257 


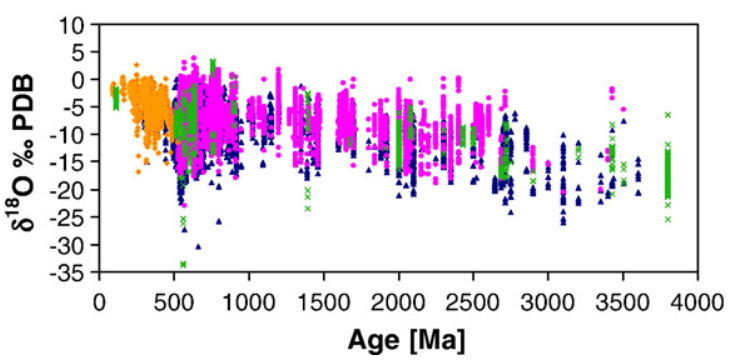

Fig. 7. Marine carbonate $\delta^{18} \mathrm{O}$ evolution of calcite (triangles), dolomite (circles), brachiopod (diamonds) and other minerals (crosses) during geologic history. All 19,257 samples of the database are incorporated into this scatter plot, including 3152 samples that were not included in the statistical analysis and modelling because their respective stratigraphic units were deemed to have been affected by diagenetic alteration or by the presence of an evaporitic setting.

carbonate samples spanning the Archean to the Cretaceous (3800 Ma-89 Ma), including the brachiopod data compiled by Veizer et al. (1999). Where available, metadata were included as well. All raw data and metadata compilations can be found both at http://www. science.uottawa.ca/geology/isotope_data and at www. IGCP512.com.

For each formation, the mean, maximum and minimum values, as well as standard deviations were determined in an alternative version of the database in order to reduce the skewed importance of more extensively sampled lithological units (cf. Shields and Veizer, 2002: Table 2). The carbonate data were divided into four main categories according to their carbonate type: calcite, dolomite, brachiopod calcite and other unspecified carbonate minerals. The dataset had to be subdivided due to differences in the various equilibrium fractionations of the carbonate types (see Sections 2.5 and 2.6).

In order to evaluate the quality of data, graphical displays such as scatter plots were employed. The articles containing $\delta^{18} \mathrm{O}$ values that were anomalously high or low for their age were re-examined, and excluded from the database if the respective carbonate samples had clearly been affected by post-depositional alteration (e.g. Samuelsson and Strauss, 1999) or restricted marine (evaporitic) conditions (e.g. Kah et al., 2001). If the carbonate samples of a formation were found to be only partially altered (e.g. data from Abell et al., 1985), all data from that formation were removed in order to avoid introducing bias. Conversely, if an article contained data from several formations, only those data pertaining to formations affected by alteration were removed (i.e. data from Schopf and Klein, 1992; Pelechaty, 1998; Kah et al., 1999; Hill and Walter, 2000).
Data from stratigraphic units with less than three samples were not included in the statistical analysis and modelling since these data were possibly unrepresentative of the stratigraphic unit. Furthermore, they mostly derived from studies where $\delta^{18} \mathrm{O}$ results were only peripheral to the research goal and so it could not be verified whether those $\delta^{18} \mathrm{O}$ values had been affected by diagenesis. Altogether, 273 calcite $(n=5159), 263$ dolomite $(n=6499), 101$ brachiopod $(n=3764)$ and 20 'other carbonate' $(n=683)$ mean values $(n=$ individual samples) were included in the analysis, with a total of 657 mean data points $(n=16,105)$.

\subsection{Graphical results}

The scatter plot of all 19,257 individual carbonate data points (Fig. 7) and their lithological mean values (Fig. 8) show that average marine carbonate $\delta^{18} \mathrm{O}$ gradually increased from about $-15 \%$ to about $0 \%$ over the last $3.8 \mathrm{Ga}$. The minimum values of both calcite and dolomite rise from about $-20 \%$ to about $-3 \%$ over $3.5 \mathrm{Ga}$, while maximum values change from about $-5 \%$ to $0 \%$ over the same period (see also Fig. 4 ).

Over the entire timescale, occasionally near-modern values (around 0\%) were determined, especially in dolomite samples (Fig. 8). Repeatedly high values were measured in the geons (100 Ma intervals; Hofmann, 1999) 2, 6-8, 12, 20, 22-23, 27 and 34. The lowest values occur during geons 5-9. In geon 24 , the minimum values are about 5\% higher than in the geons preceding and following that period. Similarly, samples of 1.0-1.2 $\mathrm{Ga}$ of age also display higher minimum values compared to their neighbouring geons.

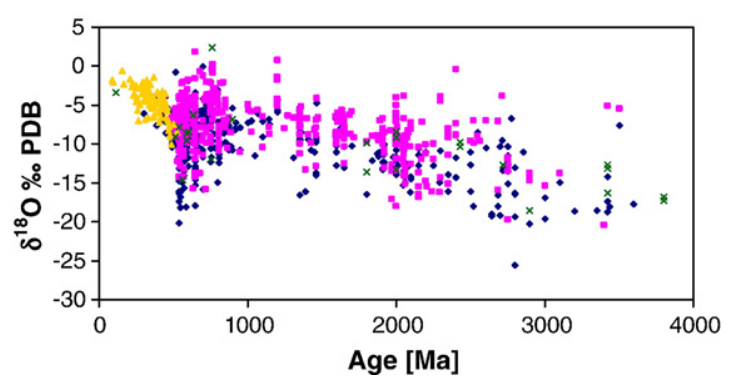

Fig. 8. Marine carbonate $\delta^{18} \mathrm{O}$ variation of calcite (diamonds), dolomite (squares), brachiopod (triangles) and other minerals (crosses) over the last $3800 \mathrm{Ma}$. Each $\delta^{18} \mathrm{O}$ data point reflects the mean value of a given stratigraphic unit, e.g. formations. All 785 mean values, including those of a sample size $<3$, are incorporated in this scatter plot. This figure also contains 128 mean values of sample sets that have not been included in the statistical analysis and modelling because they where clearly altered or from clearly evaporitic settings. 

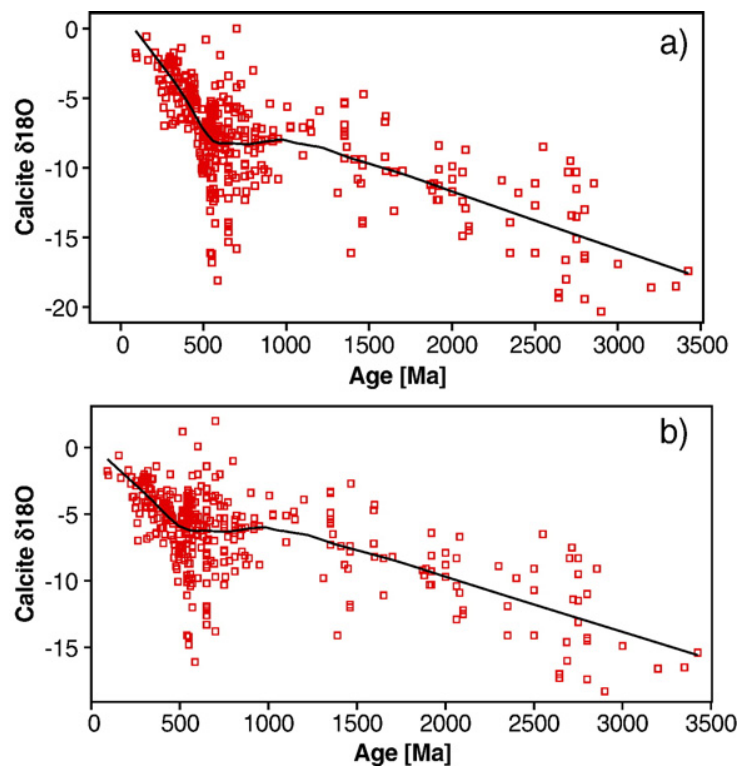

Fig. 9. Mean values of bulk rock calcite and brachiopod $\delta^{18} \mathrm{O}$ data over time for a) the measured and b) the shifted values (upward shift of $2 \%$ for all bulk rock $\delta^{18} \mathrm{O}$ data). The line of best fit was created using the Loess method. The Loess (or Lowess) method is a combination of linear least squares regression and nonlinear regression. This locally weighted smoothing method fits simple models to localised subsets of data.

Over the last $500 \mathrm{Ma}$, brachiopod data predominate, while for the previous geons, calcite and dolomite (Fig. 4) are of greater importance. Data for the early geons (before 2.8 billion years) are relatively scarce and dominated by dolomite and data of unspecified mineral composition.

\subsection{Statistical analysis and modelling}

To establish the statistical significance of the increase in the mean $\delta^{18} \mathrm{O}$ of carbonate samples with time, linear regression analysis and sample $t$-tests were carried out. Statistical analysis was performed using the statistical software package SPSS (Version 12), while the box model was executed employing the commercial software ModelMaker (Version 3, Cherwell Scientific
Publishing Limited). The oxygen isotope data utilised in ModelMaker underwent exponential smoothing using Holt's method, which assumes that the data have a linear trend and no seasonal variation. The age data of the carbonate samples also underwent exponential smoothing since ModelMaker only allows for a single data point per given age. ModelMaker solves first order differential equations using the numerical Runge-Kutta method (Press et al., 1992, pp. 710).

\subsection{Interpretation of age-carbonate relationship}

The data spread during certain geons is quite large with a range in sample values between 3\%o and 33\%. Major data scatter is very likely due to post-depositional alteration as well as to more minor primary variations such as the presence of a restricted setting (Kah, 2000). Largest variations occur between 500 and $750 \mathrm{Ma}$ (Fig. 9).

The mean oxygen isotope values of the carbonate samples display an increasing trend over time (Fig. 9) that is statistically significant at $\alpha=0.05$ for the entire carbonate data set $(P$-value $=0.000$; Table 1$)$ and for all carbonate subgroups $(P$-value $=0.000$; Table 2$)$. The mean oxygen isotope ratio steadily increased from about $-17 \%$ to about $-8 \%$ o between 3.8 and 1.2 billion years ago (Fig. 9a). Between 1.2 and $0.6 \mathrm{Ga}$, the average oxygen isotope values remained at around $-8 \%$, and thus did not display a significant increase in $\delta^{18} \mathrm{O}$ with time. It is noted, however, that the $\delta^{18} \mathrm{O}$ data spread was very large between 0.75 and $0.5 \mathrm{Ga}$. The mean oxygen isotope values increased again after 0.6 billion years ago, gradually approaching modern values (range of modern brachiopods: $-3 \%$ to $+3.5 \%$, cf. Carpenter and Lohmann, 1995; Brand et al., 2003). Fig. 9b, for which bulk rock calcite has been shifted upwards by $2 \%$ to take into account diagenetic alteration, shows the same trends as Fig. 9a. The main differences are the initial $\delta^{18} \mathrm{O}$ value of $-15 \%$, an average $\delta^{18} \mathrm{O}$ value of $-6.5 \%$ between 1.2 and $0.6 \mathrm{Ga}$, and, consequently, a shallower increase in $\delta^{18} \mathrm{O}$ towards modern values. The statistical analysis of the trend displayed by brachiopods showed

Table 1

Regression equation for the entire marine carbonate $\delta^{18} \mathrm{O}$ data set

\begin{tabular}{|c|c|c|c|c|c|c|}
\hline \multirow[t]{2}{*}{ Model } & & \multicolumn{2}{|c|}{ Unstandardized coefficients } & \multirow{2}{*}{$\frac{\text { Standardized coefficients }}{\text { Beta }}$} & \multirow[t]{2}{*}{$t$} & \multirow[t]{2}{*}{ Sig. } \\
\hline & & $\mathrm{B}$ & S.E. & & & \\
\hline 1 & $\begin{array}{l}\text { (Constant) } \\
\text { Age }\end{array}$ & $\begin{array}{r}-5.063 \\
-.003\end{array}$ & $\begin{array}{l}.197 \\
.000\end{array}$ & -.579 & $\begin{array}{l}-25.716 \\
-18.258\end{array}$ & $\begin{array}{l}.000 \\
.000\end{array}$ \\
\hline
\end{tabular}

a. Dependent Variable: AVERAGE OXYGEN. 
Table 2

Regression equations for each carbonate $\delta^{18} \mathrm{O}$ subgroup. All regression lines are significantly different from zero, i.e. the carbonate subgroup $\delta^{18} \mathrm{O}$ increases with time. With the exception of the brachiopod regression lines, the lines do not pass through the origin ( $0 \%$ opDB for modern marine carbonates) since they are based on simple linear regression equations

\begin{tabular}{|c|c|c|c|c|c|c|c|}
\hline \multirow[t]{2}{*}{ Origin } & \multirow[t]{2}{*}{ Model } & & \multicolumn{2}{|c|}{ Unstandardized coefficients } & \multirow{2}{*}{$\frac{\text { Standardized coefficients }}{\text { Beta }}$} & \multirow[t]{2}{*}{$t$} & \multirow[t]{2}{*}{ Sig. } \\
\hline & & & $B$ & S.E. & & & \\
\hline \multirow[t]{2}{*}{ Calcite } & 1 & (Constant) & -6.434 & .298 & & -21.585 & .000 \\
\hline & & age & -.003 & .000 & -.598 & -12.265 & .000 \\
\hline \multirow[t]{2}{*}{ Dolomite } & 1 & (Constant) & -5.077 & .346 & & -14.689 & .000 \\
\hline & & age & -.002 & .000 & -.486 & -9.013 & .000 \\
\hline \multirow[t]{2}{*}{ Brachiopod } & 1 & (Constant) & .883 & .587 & & 1.505 & .135 \\
\hline & & age & -.015 & .002 & -.678 & -9.178 & .000 \\
\hline \multirow[t]{2}{*}{ Other } & 1 & (Constant) & -7.417 & .992 & & -7.475 & .000 \\
\hline & & age & -.002 & .001 & -.649 & -3.622 & .002 \\
\hline
\end{tabular}

a. Dependent Variable: mean $\delta^{18} \mathrm{O}$.

that modern values are not significantly different from $0 \%$ o $(P$-value $=0.135$, Table 2$)$.

All four carbonate $\delta^{18} \mathrm{O}$ data sets show strong negative correlations with age that are significant at the 0.01 level, with Pearson correlations varying between -0.486 and -0.678 (Table 3 ). The strongest correlations are exhibited by brachiopods and data in the category 'other carbonates' ( -0.678 and -0.649 , respectively). Because the 'other carbonates' category mixes data from different minerals, this correlation is not considered to be geologically meaningful. Slightly weaker relationships with time are displayed by calcite and dolomite $(-0.598$ and -0.486 , respectively).

\subsection{Cross-correlation of carbonate data subsets}

Consistent with published literature (cf. Veizer and Hoefs, 1976; Land, 1980; Gao, 1993; Kah, 2000; Vasconcelos et al., 2005), dolomite is consistently enriched in ${ }^{18} \mathrm{O}$ over coeval limestone by about $2-3 \%$ throughout geologic time (Fig. 10). This enrichment is consistent with their equilibrium fractionation (Vasconcelos et al., 2005) and it can, therefore, be assumed that, overall, the two carbonate subgroup datasets retain original trends. The four carbonate data sets (dolomite, calcite, brachiopod and 'other') display strong positive correlations among each other (between 0.622 and 0.880; Table 4), all significant at the 0.05 level with the exception of the brachiopod-calcite correlation, which is significant at the 0.1 level due to the low sample number. The parallel trend between brachiopods and bulk carbonates supports the suggestion that diagenesis of carbonate rocks results in mineralogical stabilisation (from aragonite or high- $\mathrm{Mg}$ calcite to low-Mg calcite), and generally up to $2-3 \%$ depletion with respect to unaltered coeval brachiopods, leaving the sediments unaffected by any further chemical or physical processes (Veizer et al., 1999). The parallel trend also implies that there is no simple, linearly increasing alteration with age as has sometimes been proposed (e.g. Gao and Land, 1991) to explain the marine carbonate $\delta^{18} \mathrm{O}$ trend.

\subsection{Limitations of database}

\subsubsection{Poor age constraints}

For some of the carbonate samples, no precise age resolution is available due to both the scarceness of reliable radiometric ages and complications in stratigraphic correlations in the Precambrian. Therefore, there are some inaccuracies, especially with most Precambrian samples (Shields and Veizer, 2002), in the time plots. However, since the ages had to be smoothed, thus reducing the precision of the samples' ages, these age uncertainties did not have a significant impact on the outcome of the model.

Table 3

Correlations of the carbonate $\delta^{18} \mathrm{O}$ subgroups with age. All four subgroups display strong negative correlations with age that are significant at the 0.01 level

\begin{tabular}{lll}
\hline Origin & & Correlation with age \\
\hline Calcite & Pearson Correlation & $-.598^{\mathrm{a}}$ \\
& Sig. (2-tailed) & .000 \\
\multirow{4}{*}{ Dolomite } & $N$ & 273 \\
& Pearson Correlation & $-.486^{\mathrm{a}}$ \\
\multirow{5}{*}{ Brachiopod } & Sig. (2-tailed) & .000 \\
& $N$ & 263 \\
& Pearson Correlation & $-.678^{\mathrm{a}}$ \\
Other & Sig. (2-tailed) & .000 \\
& $N$ & 101 \\
& Pearson Correlation & $-.649^{\mathrm{a}}$ \\
& Sig. (2-tailed) & .002 \\
& $N$ & 20 \\
\hline
\end{tabular}

${ }^{\text {a }}$ Correlation is significant at the 0.01 level (2-tailed). 


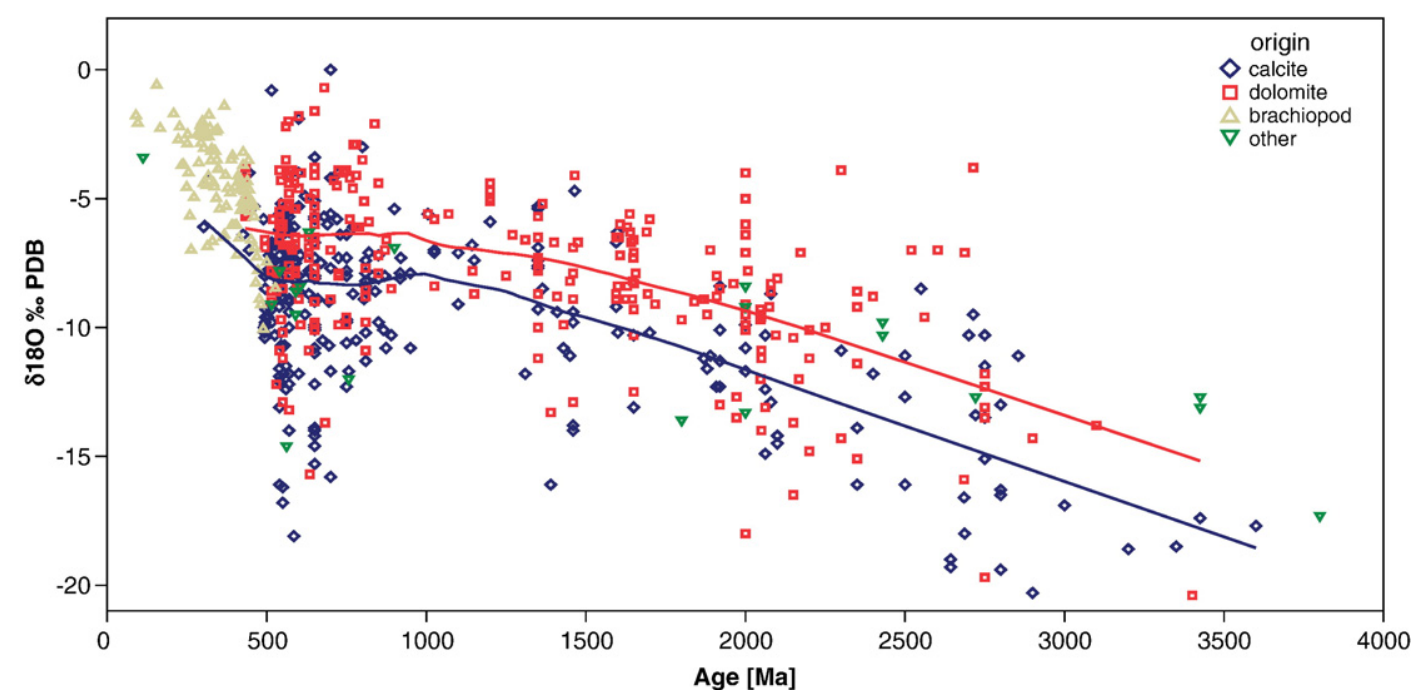

Fig. 10. Line of best fit through the mean values of calcite (lower line) and dolomite (upper line) $\delta^{18} \mathrm{O}$ data over time. The line of best fit was created using the Loess method.

\subsubsection{Causal factors of large sample spread}

Some time periods are characterised by greater data spread than others, notably between 500-750 Ma and samples older than 2000 Ma (Fig. 8). Generally, it is assumed that a large data range (within a formation or time interval) is an indication of diagenetic alteration (Perry, 1967). However, since data came from all over

Table 4

Cross-correlations of the carbonate $\delta^{18} \mathrm{O}$ subgroups. All crosscorrelations are significant at the 0.05 level with the exception of the correlation between calcite and brachiopods $(r=0.622)$ that shows a significance at $\alpha=0.1$. Unlike for the other tables, the mean $\delta^{18} \mathrm{O}$ of formations containing less than three data points were also included

\begin{tabular}{llllll}
\hline & & Calcite & Dolomite & Brachiopod & Other \\
\hline Calcite & $\begin{array}{l}\text { Pearson } \\
\text { correlation }\end{array}$ & 1 & $.639^{\mathrm{a}}$ & .622 & $.880^{\mathrm{a}}$ \\
& Sig. (2-tailed) & & .000 & .074 & .002 \\
& $\mathrm{~N}$ & 373 & 211 & 9 & 9 \\
\multirow{5}{*}{ Dolomite } & Pearson & $.639^{\mathrm{a}}$ & 1 &.${ }^{\mathrm{b}}$ & $.828^{\mathrm{c}}$ \\
& correlation & & & & \\
& Sig. (2-tailed) & .000 & &. & .011 \\
& $\mathrm{~N}$ & 211 & 385 & 0 & 8 \\
Brachiopod & Pearson & .622 &. $\mathrm{~b}$ & 1 &.${ }^{\mathrm{b}}$ \\
& correlation & & & & \\
& Sig. (2-tailed) & .074 &. & &. \\
& $\mathrm{~N}$ & 9 & 0 & 101 & 0 \\
Other & Pearson & $.880^{\mathrm{a}}$ & $.828^{\mathrm{c}}$ &. $\mathrm{b}$ & 1 \\
& correlation & & & & \\
& Sig. (2-tailed) & .002 & .011 &. & \\
& $\mathrm{~N}$ & 9 & 8 & 0 & 25 \\
\hline
\end{tabular}

\footnotetext{
${ }^{\text {a }}$ Correlation is significant at the 0.01 level (2-tailed).

${ }^{b}$ Cannot be computed because at least one of the variables is constant.

${ }^{c}$ Correlation is significant at the 0.05 level (2-tailed).
}

the world, some part of this relatively large data spread could indicate greater variability in small scale climate regimes, bathymetric differences, seasonal upwelling and salinity (Korte et al., 2005a,b), leading to higher $\delta^{18} \mathrm{O}$ in areas of net evaporation (including evaporative localities) and in cold waters, and to lower $\delta^{18} \mathrm{O}$ in seawater of warm temperature and/or low salinity. Conversely, time periods of low data spread may indicate that the Earth's climate was characterised by relatively uniform temperature and salinity. On the other hand, the variability in sample spread could simply signify that samples, collected from periods characterised by larger sample spread, derive from a wider range of paleolatitudes compared to the samples of a period with lower data scattering.

Large carbonate $\delta^{18} \mathrm{O}$ data spread due to post-depositional alteration by highly negative meteoric water $\delta^{18} \mathrm{O}$ is another possibility. Zheng et al. $(2004,2007)$ found consistently low $\delta^{18} \mathrm{O}$ equilibration in Neoproterozoic igneous rocks of about $750 \mathrm{Ma}$ age, implying alteration by meteoric waters with unusually low $\delta^{18} \mathrm{O}$ composition. Overprinting by ${ }^{18} \mathrm{O}$-depleted meteoric waters correlates in time with the onset of Neoproterozoic glaciation and so could be related to the melting of ice (Zheng et al., 2004, 2007), possibly below the base of a thick ice cap similar to sub-glacial Antarctic lakes today.

\subsubsection{Diagenetic alteration}

Although care has been taken to eliminate diagenetically altered samples, their inclusion cannot be excluded, and it is to be expected that some altered samples 
remain in the data compilation. Numerous studies lacked background information (metadata) that would enable detailed interpretation of the samples from which the $\delta^{18} \mathrm{O}$ values derive. The impact of altered samples on the overall carbonate $\delta^{18} \mathrm{O}$ trend was reduced by removing outliers (both maximum and minimum $\delta^{18} \mathrm{O}$ values) that, according to reporting authors, were clearly affected by diagenetic alteration or by deposition in an evaporitive setting.

3.6.3.1. Mean versus maximum. In much of the published literature, the maximum carbonate $\delta^{18} \mathrm{O}$ values of each formation are considered the most pristine because diagenetic alteration generally leads to a decrease in $\delta^{18} \mathrm{O}$. However, since primary or post-depositional enrichment in ${ }^{18} \mathrm{O}$ via, for example, evaporative settings (cf. Kah, 2000) cannot be excluded, it is deemed that mean $\delta^{18} \mathrm{O}$ values best represent the original $\delta^{18} \mathrm{O}$ signature and represent accurate paleotemperatures (see also Section 4.1). Usage of the commonly recommended maximum value would result in a systematic bias towards low temperatures (Kolodny and Raab, 1988). Therefore, for each study, the mean $\delta^{18} \mathrm{O}$ was computed for each formation, and utilised in the model and the statistical analysis. Even though a bias towards lower original carbonate $\delta^{18} \mathrm{O}$ may be created that way, it is reasoned that the mean value more likely represents the original carbonate $\delta^{18} \mathrm{O}$ and paleotemperatures than either the maximum or the minimum. This approach is confirmed by the consistency between Late Cambrian micrites (Fig. 3) and early marine cements and brachiopods from the Late Cambrian and Early Ordovician (Shields et al., 2003).

Nevertheless, since whole rock has sometimes been found to be depleted consistently by about $2 \%$ with respect to well preserved brachiopod shells (cf. Veizer et al., 1999) and early marine cements (cf. Johnson and Goldstein, 1993; Shields et al., 2003), an alternative more conservative scenario was used in an additional model run, in which the mean values of the whole rock calcite values were raised by $2 \%$ to take into account any systematic diagenetic shift in the whole rock $\delta^{18} \mathrm{O}$ data. Even more conservative scenarios can be imagined if only early marine cement data are chosen for the Precambrian and Cambrian (Fig. 4); however, as such data are also considerably ${ }^{18} \mathrm{O}$-depleted compared with modern equivalents, such an approach would not greatly alter the conclusions herein.

\subsubsection{Sampling bias}

3.6.4.1. Geographic bias. Most studied samples of marine carbonates (low-Mg calcitic and aragonitic shells) derive from the photic zone of palaeotropical, epicontinental seas and shelves $\left(30^{\circ} \mathrm{S}-30^{\circ} \mathrm{N}\right)$ because pelagic sediments are destroyed in subduction (Railsback, 1990; Holmden and Muehlenbachs, 1993b; Muehlenbachs, 1998; Veizer et al., 2000). Therefore, the oxygen isotopic record for much of the Phanerozoic mirrors the temperatures and isotopic compositions of the uppermost portions of epeiric seas only (Railsback, 1990). The $\delta^{18} \mathrm{O}$ values of surface waters may differ from deep waters due to dilution with meteoric waters or concentration by evaporation (Savin and Yeh, 1981; Holmden and Muehlenbachs, 1993a; Holmden et al., 1998; Muehlenbachs, 1998). It is thus possible that the Precambrian's low carbonate $\delta^{18} \mathrm{O}$ resulted from seawater ${ }^{18} \mathrm{O}$ (and salt-rich waters) mainly being stored in the deep sea (see Section 4.2). Salinity-stratification would lead to only minor $(\leq 1.5 \%){ }^{18} \mathrm{O}$-enrichment in surface waters relative to the global average composition (Railsback, 1990). Therefore, only carbonate $\delta^{18} \mathrm{O}$ shifts of a similar scale may be explained by a salinity-stratified ocean. Similarly, carbonate deposition in an epeiric sea characterised by locally very negative seawater $\delta^{18} \mathrm{O}$ due to river run-off and limited tidal mixing could explain some but not all of the low carbonate $\delta^{18} \mathrm{O}$ values. Furthermore, carbonates deposited in deeper and less restricted locations are also very ${ }^{18} \mathrm{O}$-depleted (e.g. Frank et al., 1997) indicating that there is no significant depth-related bias in carbonate $\delta^{18} \mathrm{O}$.

In addition to the depth-related sampling bias, there is also a partiality in regard to the countries and regions in which most research is performed. Generally, easily accessible sites are most likely to get repeatedly sampled and, thus, automatically gain greater importance in databases such as the present compilation. Specifically, most Precambrian (or whole rock) samples derive from Chinese, Russian, Australian and North American sites. Because of continental drift, such biased sampling also implies that the latitudinal distribution of the original depositional locations may have varied with time. That is, while, initially, most samples derived from low latitudes, the more recent data (Mesozoic and Cenozoic) originate from higher latitudes (Allison and Briggs, 1993) and from obligate calcifiers. Since, presumably, low latitudes are associated with relatively warm water compared to high latitudes, a shift towards higher carbonate $\delta^{18} \mathrm{O}$ is to be expected as the depositional setting became relatively colder due to the inverse relationship of temperature and carbonate $\delta^{18} \mathrm{O}$. Thus, parts of the carbonate $\delta^{18} \mathrm{O}$ trend can be explained by the change in latitudinal depositional setting. The interpretation of the latitudinal effect on carbonate $\delta^{18} \mathrm{O}$ is not straightforward since paleolatitudes of most of the sampled areas 
are poorly constrained. However, similar to the effect of salinity stratification, the effect of paleolatitude and covarying temperature can not account for the entire carbonate $\delta^{18} \mathrm{O}$ trend as a decrease in temperature by $10{ }^{\circ} \mathrm{C}$, for example, would lead to an increase in $\delta^{18} \mathrm{O}$ of only around 2\%o (Fig. 11; Perry, 1967; Qing and Veizer, 1994).

3.6.4.2. Sample size bias. Not all formations and groups were equally comprehensively sampled, leading to emphasis of more extensively sampled lithological units. This type of bias was reduced by calculating the mean value for each formation of every study (Shields and Veizer, 2002) and by removing small sample sizes $(\mathrm{n}<3)$ prior to performing statistical and modelling investigations. However, by calculating the mean values for each formation, the fact was ignored that not all formations cover the same period of time, thus potentially introducing greater uncertainty of age constraints.

\section{Possible explanations for $\delta^{18} \mathrm{O}$ trend}

\subsection{Diagenetic alteration}

Although it seems unlikely that wholescale lowering of $\delta^{18} \mathrm{O}$ in older marine authigenic minerals and rocks can purely be a diagenetic artefact, the likelihood that our analysis will be biased by post-depositional isotopic exchange is great and needs to be addressed here as well as in any future study. The extent and duration of the alteration pathway, as opposed to the relative stability of the final product, are the crucial factors controlling the degree of modification of the original seawater $\delta^{18} \mathrm{O}$ signal (Veizer et al., 1997). The alteration of a carbonate protolith into limestone is achieved mostly during early diagenesis, when neither the temperature nor the isotopic composition

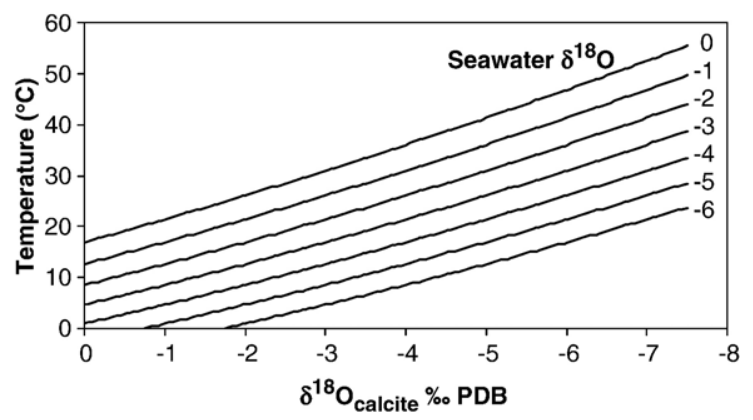

Fig. 11. Relationship between calcite $\delta^{18} \mathrm{O}$, seawater $\delta^{18} \mathrm{O}$ and temperature. The temperature equation $T{ }^{\circ} \mathrm{C}=16.9-4.38 *\left(\delta^{18} \mathrm{O}_{\mathrm{c}}-\delta^{18} \mathrm{O}_{\mathrm{sw}}\right)+$ $0.1^{*}\left(\delta^{18} \mathrm{O}_{\mathrm{c}}-\delta^{18} \mathrm{O}_{\mathrm{sw}}\right)^{\wedge 2}$ (Shackleton and Kennett, 1975) was utlised to derive the relationship. of diagenetic pore water are very different from that of ambient seawater (Choquette and James, 1990; James and Choquette, 1990a,b). Stabilisation of cherts and phosphorites, on the other hand, occurs over a prolonged period, fully accomplished only at pressures of deep burial (Hesse, 1990a,b). Because all rocks undergo a diagenetic stage, they can all potentially become altered towards lower $\delta^{18} \mathrm{O}$ values. However, it has been argued repeatedly and convincingly that thermodynamically stable minerals such as low-Mg calcite provide the most resistance against isotopic overprinting (e.g. Veizer et al., 1997).

Trace element variations in marine carbonates have commonly been used to approximate the extent of postdepositional alteration (Veizer, 1983; Popp et al., 1986a). For example, $\mathrm{Mn}$ and $\mathrm{Fe}$ are enriched in diagenetic carbonates, whereas $\mathrm{Sr}$ is generally depleted (Veizer and Fritz, 1976; Brand and Veizer, 1980; Popp et al., 1986a; Grossman et al., 1991). Consequently, $\mathrm{Mn} / \mathrm{Sr}$ or ${ }^{87} \mathrm{Sr} /{ }^{86} \mathrm{Sr}$ ratios may be applied as diagenetic proxies, which in the event of their covariation with clearly altered $\delta^{18} \mathrm{O}$ values could potentially be used to extrapolate back to near seawater $\delta^{18} \mathrm{O}$. The tendency for dolomites to lose $\mathrm{Sr}$ means that pure calcite $\delta^{18} \mathrm{O}$ can also be extrapolated in mixed dolomite/calcite samples by plotting $\mathrm{Mg} / \mathrm{Ca}$ or $\mathrm{Mn} / \mathrm{Sr}$ against $\delta^{18} \mathrm{O}$ (Fig. 5). Caution needs to be expressed in both cases though as the ubiquitousness of water in the surface environment signifies that $\delta^{18} \mathrm{O}$ values will generally be the most easily altered of commonly measured carbonate geochemical parameters. This means that diagenetic trends can only be used to determine the least altered, pristine $\delta^{18} \mathrm{O}$ value in any suite of samples. In other words, limestone samples with altered O-isotope systematics may not necessarily show any other geochemical indications of alteration.

Best-practice selection of the least-altered marine carbonate samples involves a combination of methods including scanning electron microscopy (SEM), cathodoluminescence (CL), trace element analysis and petrography (Marshall, 1992; Wadleigh and Veizer, 1992; Azmy et al., 1998). Luminescence, which in sedimentary carbonates is usually associated with manganese $\left(\mathrm{Mn}^{2+}\right.$; Nickel, 1978; Pierson, 1981; Popp et al., 1986a; Wadleigh and Veizer, 1992), is a commonly used indicator of the degree of brachiopod preservation (Popp et al., 1986a,b). Oxygenated seawater has a low $\mathrm{Mn}^{2+}$ concentration, and consequently, marine carbonates should not luminesce (Popp et al., 1986a). Conversely, $\mathrm{Mn}^{2+}$ concentrations are higher in meteoric-derived fluids (Popp et al., 1986a). However, it was concluded that luminescence is not always a decisive factor for determining the extent of alteration of samples (Popp et al., 1986a; Rush and Chafetz, 1990; Wadleigh and Veizer, 
1992; Land, 1995). This is because luminescence is also connected to, for example, the presence or absence of additional trace elements in the shell and to the rate of calcite precipitation (Fairchild, 1983; Wadleigh and Veizer, 1992). Iron $\left(\mathrm{Fe}^{2+}\right)$ is the main inhibitor of luminescence in calcite (Pierson, 1981; Popp et al., 1986a) and also tends to be enriched in samples altered by meteoric fluids (James and Choquette, 1990a; Grossman et al., 1991). If samples containing Fe-rich calcite can be identified and excluded by the use of staining techniques and chemical analysis, it was maintained that luminescence can be used directly as an indicator of diagenetic alteration in the remaining samples (Popp et al., 1986a; Grossman et al., 1991). Similarly, cathodoluminescence is a vital tool to distinguish the different generations of cements (Fairchild, 1983; Tobin and Walker, 1996; Tobin and Bergstrom, 2002).

Post-depositional processes resulting in ${ }^{18} \mathrm{O}$-enrichment are rare (Wadleigh and Veizer, 1992). Diagenetic processes normally result in ${ }^{18} \mathrm{O}$-depletion of carbonates and phosphates since alteration commonly occurs in the presence of ${ }^{18} \mathrm{O}$-depleted meteoric waters or at elevated temperatures (Land, 1980; Popp et al., 1986a; McArthur et al., 1987; Gao and Land, 1991; Marshall, 1992; Wadleigh and Veizer, 1992; Veizer et al., 1997; Kah et al., 1999; Wenzel et al., 2000; Longinelli et al., 2002; Longinelli et al., 2003). Meteoric diagenesis and burial diagenesis both permanently alter the $\delta^{18} \mathrm{O}$ of the sediment towards lower values as the sediment is transformed into a rock after sedimentation (Land, 1995). It is thus commonly argued that only the highest $\delta^{18} \mathrm{O}$ values of marine carbonates, cherts, and phosphates should be considered when evaluating the $\delta^{18} \mathrm{O}$ trend of ancient seawater (e.g. Knauth and Lowe, 1978; Gao, 1993; Longinelli et al., 2002). However, such an approach may result in a systematic bias towards low temperatures, and so it was suggested that mean oxygen values may be more representative of the actual temperature and $\delta^{18} \mathrm{O}$ trend of ancient seawater (Kolodny and Raab, 1988; see also Section 3.6.3).

Isotope samples with highest $\delta^{18} \mathrm{O}$ cannot a priori be presumed to be unaltered or representative of the global ocean. Instead, they may reflect primary variation in water composition due to evaporation in a restricted environment (Gao, 1993; Kah, 2000; Korte et al., 2005a,b). Consequently, the relatively enriched $\delta^{18} \mathrm{O}$ values usually preserved in Proterozoic early diagenetic cherts (Knauth and Epstein, 1976; Kah, 2000) may result from precipitation in primarily evaporitic $\left(\delta^{18} \mathrm{O}\right.$-enriched seawater) environments instead of recording more accurate seawater $\delta^{18} \mathrm{O}$ values (Maliva et al., 1989; Gao, 1993; Kah, 2000). Evaporitic trends in $\delta^{18} \mathrm{O}$ are well established in modern settings (Sofer and Gat, 1975; Gat and Bowser, 1991). Significantly enriched $\delta^{18} \mathrm{O}$ values within zones of subaerial exposure are consistent with dolomitisation driven by evaporative processes (Burdett et al., 1990; Kah, 2000). Evaporitive pumping mechanisms (Hsü and Siegenthaler, 1969) necessitate an upward movement of marinederived groundwater to replace the water lost to evaporation which should result in isotopic enrichment of local groundwater. It is therefore deemed necessary that careful environmental, as well as diagenetic studies are conducted when evaluating the sedimentary oxygen isotope record (Frank and Lyons, 2000; Kah, 2000).

High $\delta^{18} \mathrm{O}$ outliers can also be caused by mineralogical impurities such as the presence of dolomite (Fig. 5) or by deep marine recrystallisation. Deep waters (low temperatures) can produce carbonate sediments with high $\delta^{18} \mathrm{O}$ values relative to normal. In this regard, it was found that recrystallisation of calcareous ooze to chalk and limestone by seawater in low-temperature deep-sea conditions was associated with an increase in $\delta^{18} \mathrm{O}$ (Kastner et al., 1986). Nevertheless, all the above factors, which can increase carbonate $\delta^{18} \mathrm{O}$, tend to change measured $\delta^{18} \mathrm{O}$ values to a lesser extent than diagenetic alteration either by meteoric waters and/or at elevated temperatures. This implies that the mean $\delta^{18} \mathrm{O}$ composition of carbonates from any given interval of time will be biased systematically towards lower values, an effect which will be highly variable but has been estimated to range on average around 2\%o (Veizer et al., 1999).

Broad ranges of isotopic variation are often ascribed to post-depositional diagenetic alteration (Banner and Hanson, 1990; Ayliffe et al., 1992; Kah, 2000; Wenzel et al., 2000; Eglington et al., 2003). However, in brachiopods, for example, the main trend scatter of about 4-6\%o for any given stratigraphic interval is comparable to that observed in modern brachiopods (Veizer et al., 1997). This variation could then, perhaps, be a reflection of variability in seawater $\delta^{18} \mathrm{O}$, temperature and salinity of brachiopod habitats (Bates, 1994; Veizer et al., 1997), and in vital fractionation effects (Carpenter and Lohmann,1995). The more significant variability exhibited by the bulk carbonate record at any given time interval (Fig. 7), especially towards extremely low values, is undoubtedly an artefact of alteration. However, the limited spread of early marine calcite cement data towards the upper range of the overall data spread for any given interval (Fig. 4) should caution us from dismissing all pre-Ordovician carbonate $\delta^{18} \mathrm{O}$ data as necessarily altered.

Good correlation between detrended higher order oscillations of carbonate $\delta^{18} \mathrm{O}$ values and sedimentological 
indicators for glaciation (Veizer et al., 2000) provides strong evidence that the Phanerozoic carbonate $\delta^{18} \mathrm{O}$ trend is a primary feature. The influence of diagenetic alteration on the pre-Ordovician and, in particular, the sparse pre-Neoproterozoic carbonate $\delta^{18} \mathrm{O}$ record and its long-term increasing trend (Fig. 9) will not be known to the same extent until additional isotopic studies of global scope can be completed for that period.

\subsection{Salinity-stratified oceans}

Modern circulation has resulted in a comparatively uniform isotopic distribution with depth (Railsback, 1990). The modern oceans are thermally stratified with a sea surface temperature of about $15^{\circ} \mathrm{C}$, and deep water temperature of around $5{ }^{\circ} \mathrm{C}$ (Qing and Veizer, 1994). These temperature variations result in the nearly $2.5 \%$ difference in $\delta^{18} \mathrm{O}$ between planktonic and benthic foraminifera (Savin, 1977; Qing and Veizer, 1994). Presently, glaciation segregates ${ }^{16} \mathrm{O}$-rich waters and leaves the entire oceans (both shallow and deep) enriched in ${ }^{18} \mathrm{O}$ by $0.5-1.2 \%$ (Craig and Gordon, 1965; Shackleton and Kennett, 1975).

It was suggested that periods of a strongly salinitystratified ocean with ${ }^{18} \mathrm{O}$-rich warm saline deep waters (WSDW) occurred during the Late Ordovician (Caradocian) and the Cretaceous to early Tertiary (Brass et al., 1982; Railsback, 1990). WSDW is believed to form during periods of warm global climate, when production of cold deep waters in polar seas diminishes, and low-latitude seas are characterised by high evaporation, resulting in warm, saline waters that form the dominant deep-water mass (Wilde and Berry, 1984; Woo et al., 1992).

The ${ }^{18} \mathrm{O}$-depletion in shallow ocean waters (above the thermocline) during times of WSDW circulation may partially explain the observed isotopic trend of marine carbonates (Railsback, 1990). However, since potential large-scale salinity-stratification is restricted to few time periods (Cretaceous and Ordovician; Brass et al., 1982; Railsback, 1990), it is unlikely that these events are the cause of the carbonate $\delta^{18} \mathrm{O}$ trend. Furthermore, $\delta^{18} \mathrm{O}$ shifts in the composition of surface waters of $0.5-1.5 \%$ o (and a similar shift in carbonate compositions) would not account for the entire variation in the isotopic record from the Paleozoic to present, but may explain some second-order trends (Railsback, 1990). Similarly, locally salinity-stratified regions (Allison et al., 1998) can only explain some but not all low carbonate $\delta^{18} \mathrm{O}$ values.

\subsection{Isotope fractionation}

Carbonate $\delta^{18} \mathrm{O}$ differs from seawater $\delta^{18} \mathrm{O}$ due to isotopic fractionation, which is largely dependent on the temperature and $\mathrm{pH}$ of the solution from which the carbonate formed (Urey et al., 1951; Jean-Baptiste et al., 1997; Zeebe, 1999; Wallmann, 2004). An increase in temperature results in a decrease in isotope fractionation (Silverman, 1951; Friedman and O’Neil, 1977). The $\delta^{18} \mathrm{O}$ values of shell carbonate also depend on the marine $\mathrm{CO}_{3}^{2-}$ concentration (Spero et al., 1997; Zeebe, 1999). An increase in temperature, in marine $\mathrm{CO}_{3}^{2-}$ concentration or in $\mathrm{pH}$ (Zeebe, 1999) will lead to a decrease in $\delta^{18} \mathrm{O}$ of the calcite shells (Spero et al., 1997; Muehlenbachs, 1998; Zeebe, 1999). The following sections will discuss the impact of temperature and $\mathrm{pH}$ on carbonate $\delta^{18} \mathrm{O}$ in more detail.

\subsubsection{Seawater temperature}

A common interpretation is that the trend of increasing carbonate $\delta^{18} \mathrm{O}$ with decreasing age displayed in most studies is a primary feature induced by a progressive cooling of sea surface temperatures during Earth history (Knauth and Epstein, 1976; Kolodny and Epstein, 1976; Knauth and Lowe, 1978; Karhu and Epstein, 1986; Robert and Chaussidon, 2006). Higher paleotemperatures would have induced the precipitation of lower $\delta^{18} \mathrm{O}$ exogenic products (Perry, 1967; Muehlenbachs, 1998; Wallmann, 2001). A temperature increase of $5{ }^{\circ} \mathrm{C}$ will result in a carbonate $\delta^{18} \mathrm{O}$ decrease of about $1.0 \%$ if seawater $\delta^{18} \mathrm{O}$ remains invariable (Fig. 11; Perry, 1967; Qing and Veizer, 1994).

The deduced paleotemperatures (Fig. 2) are often criticized as being unreasonably high given abundant sedimentary evidence for early Proterozoic glaciations and reports of glacial and ice-rafted debris deposits in Neoproterozoic and Paleozoic sediments (Crowell, 1982; Caputo, 1985; Caputo and Crowell, 1985; Frakes and Francis, 1988). Knauth and Lowe (1978) countered that, on geological time scales, glaciations occur over a relatively short time interval and would thus not conflict with an overall hot climate. It was proposed that the Archean and early Proterozoic water temperatures were in the range of $\geq 60{ }^{\circ} \mathrm{C}$ (Knauth and Epstein, 1976; Knauth and Lowe, 1978; Karhu and Epstein, 1986; JeanBaptiste et al., 1997; Robert and Chaussidon, 2006). However, the co-occurrence of carbonate ooid-bearing strata with sedimentary evidence for cool waters in Neoproterozoic strata underlying glaciogenic sedimentary rocks implies that temperature fluctuations are likely to have been similar to the climatic range found in the modern marine environment (e.g. James et al., 2005) (see Section 2.3 for additional discussion of these chertbased paleotemperature constraints). In addition, although upper temperature limits for prokaryotic photoautotrophs $\left(73-75^{\circ} \mathrm{C}\right.$, Bauld and Brock, 1973) can be 
above $65{ }^{\circ} \mathrm{C}$, only a few cyanobacteria can metabolise and reproduce efficiently at these temperatures (cf. Kah, 2000). A large diversity of cyanobacteria is not observed anywhere at high temperatures $\left(\geq 65^{\circ} \mathrm{C}\right)$ in modern settings (Kah, 2000).

Likewise, temperature estimates for the Phanerozoic can also be challenged. Under the assumption that seawater $\delta^{18} \mathrm{O}$ has always remained around a constant -1\%o, Karhu and Epstein (1986) proposed that ocean water temperatures were about $45^{\circ} \mathrm{C}$ during the Cambrian, dropped to about $22{ }^{\circ} \mathrm{C}$ during the Ordovician, and rose again to about $40{ }^{\circ} \mathrm{C}$ in the Devonian before lowering to about $18{ }^{\circ} \mathrm{C}$ in the post-Devonian based on coexisting cherts and phosphates. Similar temperatures for the Ordovician and Devonian can also be inferred from brachiopods using the same assumptions (Veizer et al., 1986; Railsback et al., 1990). However, most metazoans could not survive at such high temperatures $\left(>40{ }^{\circ} \mathrm{C}\right)$ while toleration of large and abrupt temperature changes $\left(>10^{\circ} \mathrm{C} / 10 \mathrm{Myr}\right)$ by identical Paleozoic faunal communities is unlikely (Veizer et al., 1986; Carpenter et al., 1991; Qing and Veizer, 1994; Lécuyer and Allemand, 1999; Rothschild and Mancinelli, 2001). About $38{ }^{\circ} \mathrm{C}$ is considered to be the absolute upper temperature limit for modern marine communities (Kinne, 1970; Brock, 1985: Table 1). Tropical, subtidal shelf marine species can adapt to or resist lower temperatures (lower lethal limit: $\sim 10{ }^{\circ} \mathrm{C}$, Thompson and Newton, 1988: Fig. 1) more easily than higher temperatures (Thompson and Newton, 1988; Carpenter et al., 1991). Nevertheless, it could be argued that modern restrictions may not constrain past evolution since records of the activity of enzymes indicate that even metazoans could potentially live at temperatures approaching, or even exceeding, $50{ }^{\circ} \mathrm{C}$ (e.g. Cary et al., 1998; Lee, 2003).

The geologic record shows that there were prolonged glacial episodes during the Paleoproterozoic, Neoproterozoic and Palaeozoic intervals of ${ }^{18} \mathrm{O}$-depletion (Frakes, 1979, pp. 38; Veizer et al., 1986). It was suggested that even during the ice free times of the Cretaceous, the equatorial surface ocean temperatures did not exceed $34{ }^{\circ} \mathrm{C}$ assuming that atmospheric radiation and evaporation balances were similar to today's (Newell and Dopplick, 1979; Hay and DeConto, 1999), even though temperate climates extended into high latitudes (Frakes, 1979, chapter 6; Veizer et al., 1986). It is therefore maintained that seawater temperature was not the exclusive driving force behind the $\delta^{18} \mathrm{O}$ trend detected in Ordovician brachiopods (Qing and Veizer, 1994; Shields et al., 2003) and by association Precambrian, Cambrian and Ordovician bulk carbonates and calcite rock com- ponents. However, it is possible that temperature has a complementary influence on carbonate $\delta^{18} \mathrm{O}$ (Qing and Veizer, 1994). The observed oscillations of the detrended $\delta^{18} \mathrm{O}$ signal during the Phanerozoic have been interpreted as reflecting seawater temperatures and appear to correspond to greenhouse/icehouse intervals (Veizer et al., 2000).

\subsection{2. $p H$}

The marine carbonate $\delta^{18} \mathrm{O}$ record not only reflects changes in surface temperature but also depends on seawater $\mathrm{pH}$ (Wallmann, 2004). Seawater $\mathrm{pH}$ is strongly influenced by changes in $p \mathrm{CO}_{2}$ and has a significant impact on the $\delta^{18} \mathrm{O}$ values of certain marine carbonates (Usdowski and Hoefs, 1993; Spero et al., 1997; Zeebe, 1999, 2001; Zeebe and Wolf-Gladrow, 2001; Wallmann, 2004). Additionally, seawater $\mathrm{pH}$ is influenced by the concentrations of dissolved inorganic carbon and carbonate alkalinity, which are in turn influenced by the concentration of dissolved calcium ions and the saturation state of the ocean with respect to calcite (Wallmann, 2004).

Recent experimental and theoretical work has shown that seawater $\mathrm{pH}$ has a noticeable effect on the $\delta^{18} \mathrm{O}$ of calcium carbonate (e.g. foraminifera) via varying stable oxygen isotope fractionation between water and calcium carbonate (Spero et al., 1997; Zeebe, 1999, 2001; Wenzel et al., 2000). $\mathrm{pH}$ determines the ratio of $\mathrm{HCO}_{3}^{-}$ to $\mathrm{CO}_{3}^{2-}$ in solution (Zeebe, 1999). Since $\mathrm{CO}_{3}^{2-}$ is isotopically lighter than $\mathrm{HCO}_{3}^{-}, \mathrm{pH}$ controls the $\delta^{18} \mathrm{O}$ of calcium carbonate shells formed from a mixture of $\mathrm{HCO}_{3}^{-}$and $\mathrm{CO}_{3}^{2-}$ in equilibrium with seawater (Zeebe, 2001). Spero et al. (1997) demonstrated that the $\delta^{18} \mathrm{O}$ of planktonic foraminifera decreases with increasing seawater $\mathrm{CO}_{3}^{2-}$ concentration $\left[\mathrm{CO}_{3}^{2-}\right]$. As the major constituent of total dissolved inorganic carbon $\left(\Sigma \mathrm{CO}_{2}\right)$ changes from $\mathrm{HCO}_{3}^{-}$to $\mathrm{CO}_{3}^{2-}$ in solution as $\mathrm{pH}$ increases, the isotopic composition of marine carbonates decreases (Zeebe, 2001). An increase of seawater $\mathrm{pH}$ of 0.2-0.3 units, for example, results in a decrease of about $0.22-0.33 \%$ in $\delta^{18} \mathrm{O}$ of foraminiferal calcite, which is normally interpreted as a temperature increase of seawater (Zeebe, 1999). These findings suggest that the $\mathrm{pH}$ effect is a universal occurrence, although the magnitude of the effect appears to be species-dependent (Zeebe, 2001). This $\mathrm{pH}$ effect may lead to under- or overestimation of sea surface paleotemperatures (Zeebe, 2001) since biogenic carbonates may be precipitated out of isotopic equilibrium with ambient water (Wenzel et al., 2000).

Boron isotope analysis in foraminifera showed that glacial-period oceans had higher $\mathrm{pH}$ by about $0.3 \mathrm{pH}$ 
units and higher $\left[\mathrm{CO}_{3}^{2-}\right]$ than today (Sanyal et al., 1995; Spero et al., 1997). Higher $\mathrm{pH}$ values during glacial maxima would produce ${ }^{18} \mathrm{O}$-depleted shells, which result in sea surface temperature estimates that might be up to $1{ }^{\circ} \mathrm{C}$ too high since lower $\delta^{18} \mathrm{O}$ values are interpreted as higher temperatures (Zeebe, 1999). Similarly, if surface ocean $\mathrm{pH}$ was lower in the past (e.g. during periods of enhanced $p \mathrm{CO}_{2}$ ), the stable oxygen isotope fractionation between water and foraminiferal calcite would have been greater, producing isotopically heavier shells, which are wrongly interpreted as lower temperatures (Zeebe, 2001; Wallmann, 2004). Ocean surface temperatures for the mid-Cretaceous, for example, are estimated to have been $\sim 2$ $3.5{ }^{\circ} \mathrm{C}$ higher than previously thought assuming a considerably lower $\mathrm{pH}$ during that period (Zeebe, 2001; Locklair and Lerman, 2005). The effect of alkalinity changes has the potential to explain why sea surface temperature estimates based on foraminiferal $\delta^{18} \mathrm{O}$ yield low values during periods of high atmospheric $p \mathrm{CO}_{2}$ such as the Cretaceous and it is possible that this mechanism may help to resolve the 'cool tropic paradox' (D’Hondt and Arthur, 1996; Zeebe, 2001). Additionally, disequilibrium precipitation of shell calcite due to increased $\left[\mathrm{CO}_{3}^{2-}\right]$ of ambient sea water could, for example, explain the observed offset between calculated paleotemperatures from Silurian conodont and brachiopod oxygen isotope compositions (Wenzel et al., 2000).

Since a decrease of about 1.0 unit is required to achieve a $1 \%$ increase in $\delta^{18} \mathrm{O}$ (Zeebe, 1999), the much more sigificant increase in $\delta^{18} \mathrm{O}$ during geological time can not be explained by variations in $\mathrm{pH}$, which are believed to have been minor (Grotzinger and Kasting, 1993). Seawater $\mathrm{pH}$ varied by about 1.2 and 0.7 units during the Phanerozoic according to models by Locklair and Lerman (2005) and Riding and Liang (2005), respectively, and therefore, the $\mathrm{pH}$ effect on carbonate $\delta^{18} \mathrm{O}$ is unlikely to have been significant and cannot explain the entire carbonate $\delta^{18} \mathrm{O}$ trend. This conclusion is also supported by the absence of a $\mathrm{pH}$ effect in cherts, which show the same ${ }^{18} \mathrm{O}$-depletion (e.g. Knauth, 2005). Instead, it is more likely that $\mathrm{pH}$ has some influence on small-scale variations such as between glacial- and interglacial periods (Sanyal et al., 1995; Spero et al., 1997), time scales that are beyond the resolution capability of the present model, but seem to explain seawater $\delta^{18} \mathrm{O}$ changes related to temperature variability assuming either or both a $\mathrm{pH}$ and a $p \mathrm{CO}_{2}$ control. A pH variation in excess of 0.8 units in the Late Paleozoic and the Cretaceous (Locklair and Lerman, 2005: Fig. 2), for example, might explain parts of the minor $\delta^{18} \mathrm{O}$ shifts occurring during that period. Conversely, the lower $\mathrm{pH}$ of the Early Paleozoic oceans (Locklair and Lerman; Riding and Liang, 2005), would have resulted in higher carbonate $\delta^{18} \mathrm{O}$ values and thus exacerbates still further the problem of the highly ${ }^{18} \mathrm{O}$ depleted late Cambrian and early Ordovician marine carbonates, in particular (Shields et al., 2003).

\subsection{Changing seawater $\delta^{18} O$ ?}

It is generally agreed that there is currently no net ${ }^{18} \mathrm{O}-$ transfer despite considerable isotopic exchange caused by weathering, hydrothermal activity, marine diagenesis and subduction-related recycling of water (Jean-Baptiste et al., 1997; Muehlenbachs, 1998). Several studies indicate that sea-floor spreading is the driving force behind the production and maintenance of a $0 \pm 1 \%$ ocean (Muehlenbachs and Clayton, 1976; Gregory, 1991) today, although strictly speaking this value is lower as such tectonic processes control the isotopic composition of the entire surface water reservoir, which includes the water stored in ice caps. Some authors (Muehlenbachs and Clayton, 1976; Holland, 1984; Gregory, 1991; Holmden and Muehlenbachs, 1993a) have gone further and concluded that seawater $\delta^{18} \mathrm{O}$ has been buffered close to $0 \pm 1 \%$ as long as seafloor spreading operates at rates at least one half of modern average rates (Holland, 1984), with $\delta^{18} \mathrm{O}_{\mathrm{MORB}}=5.8 \pm 0.3 \%$ (Muehlenbachs, 1998). It has also been maintained that seawater $\delta^{18} \mathrm{O}$ has not changed over time significantly but has been buffered by hydrothermal and weathering processes (low-temperature interactions with silicates) at mid-ocean ridges (MORs) and on ridge flanks, based on results of ophiolite studies (Muehlenbachs and Clayton, 1976; Gregory and Taylor, 1981; Holland, 1984; Hoffman et al., 1986; Muehlenbachs, 1986; Gregory, 1991; Lécuyer and Fourcade, 1991; Muehlenbachs, 1998). High-temperature alteration (mainly via hydrothermal fluids) will lead to an increase in seawater $\delta^{18} \mathrm{O}$, while low-temperature alteration (e.g. weathering processes) will leave the ocean ${ }^{18} \mathrm{O}$-depleted (Silverman, 1951; Veizer et al., 1986; Walker and Lohmann, 1989; Qing and Veizer, 1994; Muehlenbachs, 1998; Lécuyer and Allemand, 1999; Kasting et al., 2006).

Several models suggest that seawater/rock interaction with silicates of oceanic crust at high and low temperatures balance each other and, thus, buffer seawater $\delta^{18} \mathrm{O}$ at about $0 \pm 2 \%$ (Muehlenbachs and Clayton, 1976; Gregory and Taylor, 1981; Holland, 1984, pp. 248; JeanBaptiste et al., 1997). Accepting these balances, it is impossible to produce the deduced $\geq 3 \%$ shift in Paleozoic seawater $\delta^{18} \mathrm{O}$ (Veizer et al., 1986, 2000). Nevertheless, the mass balance calculations of Gregory 
(1991) do not rule out minor variations in seawater $\delta^{18} \mathrm{O}$ over geologic timescales. Doubling of seafloor spreading rate could generate an increase of around 2\%o in seawater $\delta^{18} \mathrm{O}$ over several $100 \mathrm{Ma}$ (Gregory, 1991). Conversely, if seafloor spreading would cease, a slow decline of seawater $\delta^{18} \mathrm{O}$ would follow due to weathering, but upon restarting, a 7 times more rapid increase back to $0 \%$ would result (cf. Muehlenbachs, 1998). Even though this appears consistent with the suggested rapid shift from about $-5 \%$ to $-1 \%$ in $\delta^{18} \mathrm{O}$ at the end of the Devonian (Carpenter et al., 1991), there are no indications of early Paleozoic plate tectonic quiescence nor do older Paleozoic ophiolites record low seawater $\delta^{18} \mathrm{O}$, which argues for a constant seawater $\delta^{18} \mathrm{O}$ composition (Hoffman et al., 1986; Lécuyer and Fourcade, 1991; Muehlenbachs, 1998).

Studies of mudrocks (Land and Lynch, 1996), ophiolites (Hoffman et al., 1986; Gregory, 1991; Lécuyer and Fourcade, 1991; Holmden and Muehlenbachs, 1993a,b), microfossils (nannofossils and planktonic foraminifera, Douglas and Savin, 1975) and fluid inclusions in salt supposedly representing unmodified seawater (Knauth and Roberts, 1991) appear to indicate that seawater $\delta^{18} \mathrm{O}$ has not changed during the Phanerozoic and late Proterozoic (Land and Lynch, 1996). The $\delta^{18} \mathrm{O}$ of mudrocks does not display any systematic trend over Paleozoic and late Proterozoic time (Land and Lynch, 1996). Additionally, not all deep water Devonian brachiopods and carbonates show an increase in $\delta^{18} \mathrm{O}$ with decreasing age (Bates and Brand, 1991; Gao, 1993). The progressive ${ }^{18} \mathrm{O}$-depletion of sedimentary rocks with increasing age has commonly been explained, therefore, as the result of postdepositional weathering involving meteoric waters (Longinelli, 1966; Longinelli and Nuti, 1968a; Land, 1995; Land and Lynch, 1996; Muehlenbachs, 1998; Lécuyer and Allemand, 1999). In the case of mudrocks, the absence of a $\delta^{18} \mathrm{O}$ trend can be explained by the largely detrital origin of most marine clays, which renders mudrocks of poor utility as a seawater $\delta^{18} \mathrm{O}$ proxy (Veizer, 1999). In the case of fluid inclusions in salt, this work has only been carried out for midPalaeozoic samples, i.e. samples deposited towards the end stages of the long-term trend to more modern $\delta^{18} \mathrm{O}$ values. Brachiopods during this time interval already show near modern $\delta^{18} \mathrm{O}$ values (Korte et al., 2004). Moreover, Knauth and Roberts (1991) studied fluid inclusions in evaporite minerals which would anyway not normally be expected to be representative of the open ocean. More such studies on other intervals of Earth history, more relevant to the $\delta^{18} \mathrm{O}$ debate, would be most welcome.
Despite widespread scepticism, a group of researchers argues that $\delta^{18} \mathrm{O}$ of seawater has been increasing since about the early Paleozoic (Weber, 1955; Perry, 1967; Fritz, 1971; Perry and Tan, 1972; Popp et al., 1986a; Veizer et al., 1986; Lohmann and Walker, 1989; Walker and Lohmann, 1989; Carpenter et al., 1991; Qing and Veizer, 1994; Veizer, 1995; Veizer et al., 1997; Wallmann, 2001; Kasting et al., 2006). It is maintained that the $\delta^{18} \mathrm{O}$ of the ocean can only change very slowly since the residence time of water in the ocean is very long compared to hydrothermal circulation $\left(10^{7}\right.$ years; cf. Land and Lynch, 1996), and rates of chemical weathering on the continents are slow (Muehlenbachs and Clayton, 1976; Gregory, 1991), although continental weathering rate estimates vary greatly between $0.2 \mathrm{~km}^{3} / \mathrm{yr}$ and $7.4 \mathrm{~km}^{3} / \mathrm{yr}$ (cf. Gregory, 1991). Gregory (1991) estimated that changes in both the ocean floor spreading rate and weathering rate of continental rocks do not permit $\delta^{18} \mathrm{O}$ fluctuations greater than about $1 \%$ / $100 \mathrm{Ma}$. It was also suggested that the evolution of subaerial rifting into submarine spreading with extensive hydrothermal circulation might have shifted the seawater $\delta^{18} \mathrm{O}$ balance, causing a change from an ${ }^{18} \mathrm{O}$ deficient Neoproterozoic ocean into a Phanerozoic ocean influenced by increased ${ }^{18} \mathrm{O}$ inputs (Wallmann, 2001). Some scientists believe that the present input of ${ }^{18} \mathrm{O}$ into the ocean (through hydrothermal circulation at spreading centres and volcanic water emissions at subduction zones) still exceeds the ${ }^{18} \mathrm{O}$-consumption via weathering of continental rocks and seafloor alteration processes, thus leading to further increases in $\delta^{18} \mathrm{O}$ (Wallmann, 2001).

Some (e.g. Veizer et al., 1986; Jean-Baptiste et al., 1997; Azmy et al., 1998; Lécuyer and Allemand, 1999) considered the possibility that the low carbonate $\delta^{18} \mathrm{O}$ could have been caused by a combination of lower seawater $\delta^{18} \mathrm{O}$ and varying seawater temperatures. As low temperatures enhance the ${ }^{18} \mathrm{O}$ uptake in carbonates and other authigenic phases, the correlation between high $\delta^{18} \mathrm{O}$ and glacial periods implies that the marine fossil $\delta^{18} \mathrm{O}$ record reflects both a continuous increase of seawater $\delta^{18} \mathrm{O}$ values as well as changing sea surface temperatures (Lécuyer and Allemand, 1999; Wallmann, 2001).

\subsection{Controls on seawater $\delta^{18} \mathrm{O}$}

Sections 3.6 and 4.1-4.4 document that the marine carbonate $\delta^{18} \mathrm{O}$ trend most likely resulted from the evolution of an initially strongly ${ }^{18} \mathrm{O}$-depleted ocean towards a less depleted modern ocean $\left(\delta^{18} \mathrm{O} \approx-0.3 \%\right.$ ) over geologic time. Other factors (sampling bias, 
diagenesis, salinity-stratification and fractionation changes) cannot explain the entire carbonate $\delta^{18} \mathrm{O}$ trend. Their contributions are more likely limited to the residual short-term variability and data scatter in carbonate $\delta^{18} \mathrm{O}$. Decreases in carbonate $\delta^{18} \mathrm{O}$ during warm periods, and increases during cool periods, are expected to be superimposed on a general trend of increasing carbonate $\delta^{18} \mathrm{O}$ due to rising seawater $\delta^{18} \mathrm{O}$ (cf. Veizer et al., 2000). In the subsequent text, processes affecting the seawater $\delta^{18} \mathrm{O}$ composition are reviewed.

\subsubsection{Submarine alteration}

Presently, the oxygen isotope composition of the ocean is mainly regulated by its interactions with the oceanic crust (Muehlenbachs and Clayton, 1976; Holmden and Muehlenbachs, 1993a). While hydrothermal circulation at spreading centres, recycling of subducted water and volcanic water emissions at subduction zones lead to higher seawater $\delta^{18} \mathrm{O}$, seawater ${ }^{18} \mathrm{O}$ is sequestered by continental weathering, lowtemperature seafloor alteration processes, and precipitation and sedimentation processes in the ocean (Lawrence et al., 1975; Muehlenbachs and Clayton, 1976; JeanBaptiste et al., 1997; Muehlenbachs, 1998; Wallmann, 2001).

Seawater, which penetrates the oceanic crust at ridges, reacts with the seafloor $\left(\delta^{18} \mathrm{O}_{\mathrm{MORB}}=+5.8 \pm 0.3 \%\right.$ ) during its formation and aging at both low and high temperatures (Muehlenbachs and Clayton, 1976; Holmden and Muehlenbachs, 1993a; Muehlenbachs, 1998). During lowtemperature processes (e.g. submarine weathering, shallow ridge circulation), seawater preferentially loses ${ }^{18} \mathrm{O}$ to mid-oceanic ridge basalts, whereas high-temperature interactions $\left(\geq 350{ }^{\circ} \mathrm{C}\right.$, principally via hydrothermal fluids, but also plutonism, deep ocean ridge circulation) extract ${ }^{18} \mathrm{O}$ from the oceanic crust and release it to the ocean (Muehlenbachs and Clayton, 1976; Holland, 1984, pp. 242; Veizer et al., 1986; Walker and Lohmann, 1989; Qing and Veizer, 1994; Jean-Baptiste et al., 1997; Muehlenbachs, 1998; Lécuyer and Allemand, 1999). The largest ${ }^{18} \mathrm{O}$-input into the ocean is produced through high-temperature fluids at spreading centres (Jean-Baptiste et al., 1997; Wallmann, 2001). A study by Jean-Baptiste et al. (1997) showed that hydrothermal fluids are enriched in ${ }^{18} \mathrm{O}$ between $0.5 \%$ and $2.3 \%$ relative to ambient seawater, independent of the spreading rate or the tectonic environment, which therefore confirms that seawaterbasalt interaction at high temperature is a source of ${ }^{18} \mathrm{O}$ to the ocean. Low-temperature alteration of the constantly extruded basalts at mid-ocean ridges is a large sink for ${ }^{18} \mathrm{O}$ from the hydrosphere (Gregory and Taylor, 1981; Bowers and Taylor, 1985; Muehlenbachs, 1998; Wallmann, 2001).
The regular occurrence of low $\delta^{18} \mathrm{O}$ values for old marine sediments could signify that the ratio of highversus low-temperature processes may have changed through time (Veizer et al., 1986; Lécuyer and Allemand, 1999). Increasing the proportion of high-temperature processes at mid-ocean ridges would increase the ${ }^{18} \mathrm{O}$ content of seawater whilst an intensification of lowtemperature seafloor alteration and continental weathering would lower seawater $\delta^{18} \mathrm{O}$ values (Walker and Lohmann, 1989; Lécuyer and Allemand, 1999; Veizer et al., 1999; Goddéris and Veizer, 2000; Wallmann, 2001). Therefore, an imbalance between high-temperature hydrothermal reactions and low-temperature alteration of oceanic and continental crust over geologic time may have resulted in secular variation of seawater $\delta^{18} \mathrm{O}$ (Lohmann and Walker, 1989; Walker and Lohmann, 1989; Carpenter et al., 1991). The extent of hydrothermal alteration at mid-ocean ridges and on ridge flanks is determined by the spreading rate, with lower spreading rates leading to a decrease in both low- (due to reduced crust permeability) and high-temperature alteration (due to diminished water recycling at subduction zone and reduced hydrothermal circulation in mid-ocean ridges; Fornari and Embley, 1995; Wallmann, 2001). The net effect of lower seafloor spreading rates appears to be an increase in the relative importance of low-temperature silicate exchange reactions, resulting in lower seawater $\delta^{18} \mathrm{O}$ values (Holland, 1984, pp. 242; Wallmann, 2001). Assuming that seafloor spreading determines $\delta^{18} \mathrm{O}$ of the ocean, Holland (1984, pp. 248) calculated that seawater $\delta^{18} \mathrm{O}$ will generally remain between $-2 \%$ and $+1 \%$ o unless seafloor spreading nearly ceases (in this case, $\delta^{18} \mathrm{O}$ would approach $-10 \%$ ).

The suggestion that the long-term rising linear marine carbonate $\delta^{18} \mathrm{O}$ trend over geologic time may have been tectonically controlled is supported by the strong correlation $(r=-0.57$ to -0.84$)$ of $\delta^{18} \mathrm{O}$ with ${ }^{87} \mathrm{Sr} /{ }^{86} \mathrm{Sr}$ for Phanerozoic seawater (Veizer et al., 1999). Since seawater ${ }^{87} \mathrm{Sr} /{ }^{86} \mathrm{Sr}$ is regulated primarily by river inputs of $\mathrm{Sr}$ (weathering of ancient, ${ }^{87} \mathrm{Sr}$-enriched continental crust) and from hydrothermal circulation cells at mid-ocean ridges (interaction with young, ${ }^{87} \mathrm{Sr}$-depleted basalts), $\mathrm{Sr}$ isotopes are a proxy for hydrothermal and terrestrial tectonic processes (Peterman et al., 1970; Veizer and Compston, 1976; Veizer et al., 1999, 2000; Shields et al., 2003). According to a model based on ophiolite data by Walker and Lohmann (1989), $\delta^{18} \mathrm{O}$ can range from $-15 \%$ to $+4 \%$ depending on whether low- or high-temperature processes prevail. Because of the large reservoir size, seawater $\delta^{18} \mathrm{O}$ reacts only very slowly (about $1 \% / 10^{8}$ years; Walker and Lohmann, 1989; Gregory, 1991) to changing inputs so that a sudden change in ${ }^{18} \mathrm{O}$ fluxes could produce 
a long-term secular trend in marine $\delta^{18} \mathrm{O}$ (Wallmann, 2001).

\subsubsection{Continental weathering}

It is often assumed that continental weathering, although within an order of magnitude of that for the submarine alteration of the upper crust $\left(1.8 \mathrm{~km}^{3} /\right.$ year, Holland, 1984), is of lesser importance in the water oxygen cycle (e.g. Jean-Baptiste et al., 1997). However, estimates of continental weathering rate and the resulting ${ }^{18} \mathrm{O}$-flux into the ocean vary greatly, with weathering rates ranging from $0.2 \mathrm{~km}^{3} / \mathrm{yr}$ (Muehlenbachs and Clayton, 1976) to $7.4 \mathrm{~km}^{3} / \mathrm{yr}$ (Holland, 1984). Additionally, continental fractionation factors between rock forming minerals and water at ambient near Earth surface temperatures are large $(+10$ to $+35 \%$ o due to the low weathering temperatures (Muehlenbachs, 1998; Wallmann, 2001). Reactions of meteoric waters with rocks during continental weathering lead to ${ }^{18} \mathrm{O}$-enrichment in rocks and produce an analogous decrease in the $\delta^{18} \mathrm{O}$ values of meteoric and ocean waters (cf. Jean-Baptiste et al., 1997). Due to the large water fluxes associated with the continental hydrological cycle (river run-offs $=10^{6} \mathrm{~m}^{2} / \mathrm{s}$ ), even a small shift in $\delta^{18} \mathrm{O}$ of the meteoric waters due to a change in the intensity of weathering (caused by variability in rock-type dominance, temperature, $\mathrm{pCO}_{2}$ or river run-off) could have a significant impact on seawater $\delta^{18} \mathrm{O}$ (Jean-Baptiste et al., 1997; Dessert et al., 2003; Barley et al., 2005). Basalts and ultra-mafic rocks, for example, are more easily weathered than most other crystalline silicate rocks (Amiotte Suchet and Probst, 1993). Higher $\mathrm{pCO}_{2}$ levels and outgassing rates during the Archean (Kasting, 1987; Des Marais, 1994), combined with the dominance of easily weathered rocks such as greenstones (De Wit, 1998), are therefore likely to have led to higher weathering rates during that period than today.

Periods of extremely high seawater ${ }^{87} \mathrm{Sr} /{ }^{86} \mathrm{Sr}$ relative to crust and mantle isotopic evolution curves are evident at $\sim 2.0 \mathrm{Ga}$ and more remarkably at $0.5 \mathrm{Ga}$ (Shields and Veizer, 2002). The $0.5 \mathrm{Ga}$ event is considered to be associated with increased erosion rates resulting from the Pan-African and the Transgondwanan orogenies (Squire et al., 2006), which supplied large amounts of fine-grained silicates, including soil-derived clay minerals to the ocean (Kennedy et al., 2006). If high ${ }^{87} \mathrm{Sr} /{ }^{86} \mathrm{Sr}$ at this time was related to a prolonged interval of higher than normal rates of chemical weathering, as seems likely (Kennedy et al., 2006), then these global tectonic events may have contributed to low seawater $\delta^{18} \mathrm{O}$ during the early Phanerozoic. Furthermore, when detrital minerals are deposited on the seafloor, diagenesis, e.g. illitisation, tends to equilibrate clay $\delta^{18} \mathrm{O}$ with seawater and further depletes seawater in $\delta^{18} \mathrm{O}$ (Stille and Shields, 1997: Fig. 6.15). The extraordinary depletion of ${ }^{18} \mathrm{O}$ in Cambrian and Early Ordovician carbonates (Fig. 3) may relate to some extent to this orogenic event, but quantification of specific orogenic events lies outside the scope of the present paper.

\section{Geochemical modelling}

\subsection{Model construction}

\subsubsection{Introduction to seawater $\delta^{18} O$ modelling}

Numerous models have been constructed in an effort to decipher the meaning of the carbonate $\delta^{18} \mathrm{O}$ trend and investigate seawater $\delta^{18} \mathrm{O}$ evolution. When modelling $\delta^{18} \mathrm{O}$ using mass fluxes, there were wide margins of error, resulting in significantly different modelling outcomes (Holland, 1984; Jean-Baptiste et al., 1997). Even models which led to the same conclusion (e.g. buffered seawater $\delta^{18} \mathrm{O}$ ) used mass fluxes and parameter values that differed greatly, illustrating the uncertainty associated with them. The outcome of many models was that seawater $\delta^{18} \mathrm{O}$ is buffered at about $0 \pm 2 \%$ due to the counterbalancing effect of low- and high-temperature alteration (Muehlenbachs and Clayton, 1976; Gregory and Taylor, 1981; Holland, 1984, pp. 248; Gregory, 1991; Jean-Baptiste et al., 1997; Muehlenbachs, 1998). In general, fluxes were varied in order to achieve a balance between ${ }^{18} \mathrm{O}$ removal and uptake; however, if the $\delta^{18} \mathrm{O}$ value of seawater were capable of changing, modern flux estimates would be incorrect or inapplicable to ancient ocean systems.

$\mathrm{Li}$ (1972) was the first to suggest that ocean $\delta^{18} \mathrm{O}$ was at a steady-state. Chase and Perry (1972), on the other hand, concluded that the ${ }^{18} \mathrm{O}$ oceanic budget was not balanced and that ocean $\delta^{18} \mathrm{O}$ was likely to have varied throughout most of Earth history. Their model was contested by Muehlenbachs and Clayton (1976) who reestimated the ${ }^{18} \mathrm{O}$ budget of the main rock reservoirs and concluded that seawater $\delta^{18} \mathrm{O}$ was indeed buffered at its present value. Walker and Lohmann (1989), however, concluded that $\delta^{18} \mathrm{O}$ can vary between $-15 \%$ and $+4 \%$ o depending on the relative contributions of low- versus high-temperature alteration to the oceanic O-isotope budget. To date, there is still no agreement among geochemists as to whether seawater $\delta^{18} \mathrm{O}$ is buffered and therefore invariable (Muehlenbachs, 1998) or not (Wallmann, 2001, 2004).

\subsubsection{Parameter definitions}

The current model closely follows the box model by Wallmann (2001). The model was constructed assuming 
that the carbonate trend mainly reflects seawater $\delta^{18} \mathrm{O}$ evolution, with the residual reflecting temperature variability. The mean value is used in our model as it represents the most robust test possible of the compatibility between unchanging ophiolite $\delta^{18} \mathrm{O}$ and changing seawater $\delta^{18} \mathrm{O}$. Two scenarios are presented, one in which the mean values of calcite are used, and a conservative scenario were calcite mean values are shifted upwards by $2 \%$ to take into account diagenetic alteration. Water- and ${ }^{18} \mathrm{O}$-fluxes, mass balances for free water and ${ }^{18} \mathrm{O}$, as well as time-dependent parameters and constants are shown in Tables 5-8.

5.1.2.1. Temperature. Because of the inverse relation between isotope fractionation and temperature, the isotopic composition of carbonate, precipitated in isotopic equilibrium from water with a known isotopic composition, can be used to deduce the temperature at which the calcite was precipitated. The empirically derived temperature equation that is used most frequently in work with calcite is as follows:

$$
\begin{aligned}
T \oint \mathrm{C}=16.9 & -4.38^{*}\left(\delta^{18} \mathrm{O}_{\mathrm{c}}-\delta^{18} \mathrm{O}_{\mathrm{sw}}\right) \\
& +0.1^{*}\left(\delta^{18} \mathrm{O}_{\mathrm{c}}-\delta^{18} \mathrm{O}_{\mathrm{sw}}\right)^{\wedge 2}
\end{aligned}
$$

in which $\delta^{18} \mathrm{O}_{\mathrm{c}}(\mathrm{PDB})$ is the oxygen isotopic composition of calcite, $\delta^{18} \mathrm{O}_{\mathrm{sw}}$ (SMOW) the oxygen isotopic composition of the water from which it was precipitated (cf. Shackleton and Kennett, 1975 and references therein). At constant $\delta^{18} \mathrm{O}_{\mathrm{sw}}$, a temperature change of about $5{ }^{\circ} \mathrm{C}$ corresponds to a change in $\delta^{18} \mathrm{O}_{\mathrm{c}}$ of about $1 \%$ (Fig. 11). Modern ocean water has an overall average $\delta^{18} \mathrm{O}$ of around $-0.28 \%{ }_{\text {sMow }}$ (Shackleton and Kennett, 1975).

5.1.2.2. Mantle water emission. The mantle water emission into the ocean was changed according to the equation:

$F_{m}(0)=F_{m}(0)_{\mathrm{c}} * 5 * \sqrt{\left(\frac{-t}{3800}\right)} \quad$ for $t \leq-955$,

where $F_{m}(0)_{\mathrm{c}}$ is the current value of $3 * 10^{+18} \mathrm{~mol} / \mathrm{Myr}$ and $t$ is time. For all other times $(t>-955)$, the modern value $\left(3 * 10^{+18} \mathrm{~mol} / \mathrm{Myr}\right)$ was assumed.

5.1.2.3. Spreading rate. The spreading rate was taken to be initially 11 times higher than the current tectonic rate, and decreased exponentially to current rates as it is assumed to be proportional to the square of heat loss (Fig. 12; cf. Phipps Morgan, 1998).
Table 5

\begin{tabular}{|c|c|}
\hline Flux & Equation \\
\hline $\begin{array}{l}\mathrm{H}_{2} \mathrm{O} \text { fixation in weathering } \\
\text { products }\end{array}$ & $F_{\mathrm{w}}=f_{\mathrm{sp}} * F_{\mathrm{w}}(0)$ \\
\hline $\begin{array}{l}\mathrm{H}_{2} \mathrm{O} \text { uptake in upper crust } \\
\quad(0-500 \mathrm{~m})\end{array}$ & $F_{\mathrm{alt}}=f_{\mathrm{sp}} * F_{\mathrm{alt}}(0)$ \\
\hline $\begin{array}{l}\mathrm{H}_{2} \mathrm{O} \text { uptake in deep crust } \\
\quad(>500 \mathrm{~m})\end{array}$ & $F_{\mathrm{sp}}=f_{\mathrm{sp}} * F_{\mathrm{sp}}(0)$ \\
\hline $\begin{array}{l}\mathrm{H}_{2} \mathrm{O} \text { release from weathering } \\
\text { products }\end{array}$ & $F_{\text {rew }}=r_{\mathrm{w}} * F_{\mathrm{w}}$ \\
\hline $\begin{array}{l}\mathrm{H}_{2} \mathrm{O} \text { release from upper crust } \\
\text { at subduction }\end{array}$ & $F_{\text {reup }}=r_{\text {up }} * F_{\text {alt }}$ \\
\hline $\begin{array}{l}\mathrm{H}_{2} \mathrm{O} \text { release from deep crust } \\
\text { at subduction zones }\end{array}$ & $F_{\text {redeep }}=r_{\text {deep }} * F_{\mathrm{sp}}$ \\
\hline $\begin{array}{l}\mathrm{H}_{2} \mathrm{O} \text { release through } \\
\text { mantle degassing }\end{array}$ & $F_{m}=f_{\mathrm{sp}} * F_{m}(0)$ \\
\hline $\begin{array}{l}{ }^{18} \mathrm{O} \text { uptake in continental } \\
\text { weathering products }\end{array}$ & $F_{\mathrm{w}}^{18}=\frac{\alpha_{\mathrm{w}} * R_{\mathrm{f}}}{1+\alpha_{\mathrm{w}} * R_{\mathrm{f}}} * F_{\mathrm{w}}$ \\
\hline $\begin{array}{l}{ }^{18} \mathrm{O} \text { uptake in upper crust } \\
\quad(0-500 \mathrm{~m})\end{array}$ & $F_{\mathrm{alt}}^{18}=\frac{\alpha_{\mathrm{sp}} * R_{\mathrm{f}}}{1+\alpha_{\mathrm{sp}} * R_{\mathrm{f}}} * F_{\mathrm{alt}}$ \\
\hline $\begin{array}{l}{ }^{18} \mathrm{O} \text { uptake in deep crust } \\
(>500 \mathrm{~m})\end{array}$ & $F_{\mathrm{sp}}^{18}=\frac{\alpha_{\mathrm{deep}} * R_{\mathrm{f}}}{1+\alpha_{\mathrm{deep}} * R_{\mathrm{f}}} * F_{\mathrm{sp}}$ \\
\hline
\end{tabular}

Water fluxes and ${ }^{18} \mathrm{O}$ turnover considered in the box model

${ }^{18} \mathrm{O}$ exchange during weathering

${ }^{18} \mathrm{O}$ exchange between upper crust and seawater

${ }^{18} \mathrm{O}$ exchange between deep crust and seawater

${ }^{18} \mathrm{O}$ loss during porewater formation and recycling

$\mathrm{H}_{2}^{18} \mathrm{O}$ release from weathering products

$\mathrm{H}_{2}^{18} \mathrm{O}$ release from upper crust at subduction zones

$\mathrm{H}_{2}^{18} \mathrm{O}$ release from deep crust at subduction zones

$\mathrm{H}_{2}^{18} \mathrm{O}$ release through mantle degassing

formation of sedimentary rock

formation of upper crust ${ }^{18} \mathrm{O}$ at spreading zones

formation of deep crust ${ }^{18} \mathrm{O}$ at spreading zones

metamorphosis of sedimentary rock ${ }^{18} \mathrm{O}$

subduction of upper crust ${ }^{18} \mathrm{O}$

subduction of deep crust ${ }^{18} \mathrm{O}$

$$
\begin{aligned}
& F_{\mathrm{w}}^{\mathrm{ex}}=f_{\mathrm{sp}} * k_{\mathrm{w}} *\left(\Omega_{\mathrm{w}}-1\right) \\
& F_{\mathrm{up}}^{\mathrm{ex}}=f_{\mathrm{sp}} * k_{\mathrm{up}} *\left(\Omega_{\mathrm{up}}-1\right) \\
& F_{\mathrm{deep}}^{\mathrm{ex}}=f_{\mathrm{sp}} * k_{\mathrm{deep}} *\left(\Omega_{\mathrm{deep}}-1\right) \\
& F_{\mathrm{pw}}^{18}=f_{\mathrm{sp}} * F_{\mathrm{pw}}^{18}(0) \\
& F_{\mathrm{rew}}^{18}=\Phi_{\mathrm{w}} * F_{\mathrm{rew}} \\
& F_{\text {reup }}^{18}=\Phi_{\mathrm{up}} * F_{\text {reup }} \\
& F_{\text {redeep }}^{18}=\Phi_{\mathrm{deep}} * F_{\text {redeep }} \\
& F_{\mathrm{m}}^{18}=\Phi_{\mathrm{m}} * F_{m} \\
& F_{\mathrm{ps}}^{18}=\Phi_{\mathrm{si}} * f_{\mathrm{sp}} * F_{\mathrm{ps}}(0) \\
& F_{\mathrm{pup}}^{18}=\Phi_{\mathrm{oc}} * f_{\mathrm{sp}} * F_{\mathrm{pup}}(0) \\
& F_{\mathrm{pdeep}}^{18}=\Phi_{\mathrm{oc}} * f_{\mathrm{sp}} * F_{\mathrm{pdeep}}(0) \\
& F_{\mathrm{ms}}^{18}=\Phi_{\mathrm{w}} * f_{\mathrm{sp}} * F_{\mathrm{ps}}(0)+\Phi_{\mathrm{w}} * \\
& \left(1-r_{\mathrm{w}}\right) * F_{\mathrm{w}} \\
& F_{\text {sup }}^{18}=\Phi_{\mathrm{up}} * f_{\mathrm{sp}} * F_{\mathrm{pup}}(0)+\Phi_{\mathrm{up}} * \\
& \left(1-r_{\mathrm{up}}\right) * F_{\mathrm{alt}} \\
& F_{\mathrm{sdeep}}^{18}=\Phi_{\mathrm{deep}} * f_{\mathrm{sp}} * F_{\mathrm{pdeep}}(0)+ \\
& \Phi_{\mathrm{deep}} *\left(1-r_{\mathrm{deep}}\right) * F_{\mathrm{sp}} \\
&
\end{aligned}
$$

5.1.2.4. New features. While most variables and constants were retained from Wallmann (2001), a few parameters were changed or added in order to 
Table 6

Mass balances for free water and ${ }^{18} \mathrm{O}$ used in the box model

Reservoir Differential equation

Change in free $\mathrm{H}_{2} \mathrm{O}$ mass

$\frac{\mathrm{d} M_{f}}{\mathrm{~d} t}=F_{\text {rew }}+F_{\text {reup }}+F_{\text {redeep }}+F_{m}-F_{\mathrm{w}}-F_{\text {alt }}-F_{\text {sp }}$

Change in free $\mathrm{H}_{2}^{18} \mathrm{O}$ mass

$\frac{\mathrm{d} M_{f}^{18}}{\mathrm{~d} t}=F_{\text {rew }}^{18}+F_{\text {reup }}^{18}+F_{\text {redeep }}^{18}+F_{m}^{18}+F_{\mathrm{w}}^{\mathrm{ex}}+F_{\text {up }}^{\mathrm{ex}}+F_{\mathrm{deep}}^{\mathrm{ex}}-F_{\mathrm{w}}^{18}-F_{\text {alt }}^{18}-F_{\mathrm{sp}}^{18}-F_{\mathrm{pw}}^{18}$

Change in ${ }^{18} \mathrm{O}$ mass in sedimentary rocks

$\frac{\mathrm{d} M_{w}^{18}}{\mathrm{~d} t}=F_{\mathrm{ps}}^{18}+F_{\mathrm{w}}^{18}+F_{\mathrm{pw}}^{18}-F_{\mathrm{w}}^{\mathrm{ex}}-F_{\mathrm{rew}}^{18}-F_{\mathrm{ms}}^{18}$

Change in ${ }^{18} \mathrm{O}$ mass in upper crust

$$
\frac{\mathrm{d} M_{u p}^{18}}{\mathrm{~d} t}=F_{\text {pup }}^{18}+F_{\text {alt }}^{18}-F_{\text {up }}^{\text {ex }}-F_{\text {reup }}^{18}-F_{\text {sup }}^{18}
$$

Change in ${ }^{18} \mathrm{O}$ mass in deep crust

$$
\frac{\mathrm{d} M_{\text {deep }}^{18}}{\mathrm{~d} t}=F_{\text {pdeep }}^{18}+F_{\text {sp }}^{18}-F_{\text {deep }}^{e x}-F_{\text {redeep }}^{18}-F_{\text {sdeep }}^{18}
$$

investigate whether it is possible that seawater $\delta^{18} \mathrm{O}$ closely tracked carbonate $\delta^{18} \mathrm{O}$ over the last 3.4 billion years. Additionally, the present model was applied over a much longer interval of time $(3.4 \mathrm{Ga})$ as opposed to only covering the Phanerozoic (600 Ma). The kinetic constants, which define the exchange of ${ }^{18} \mathrm{O}$ during silicate weathering and alteration of upper and lower crust, were kept invariable in Wallmann (2001). In the current model, however, they were allowed to vary over time in order to take into account variations in $\delta^{18} \mathrm{O}$ exchange between the ocean and the lithosphere over time (Fig. 13). Conversely, the recycling efficiency $r_{\text {deep }}$ was kept constant throughout the last 3.4 billion years.

\subsubsection{Non-standard runs}

5.1.3.1. Serpentinisation. Serpentinisation $\left(F_{\text {serp }}\right)$, which, as opposed to the other water fluxes, is assumed to be independent of spreading rate (cf. Charlou et al., 2002; Wallmann, 2004), was added as a separate water uptake flux. There is no direct information about the extent of serpentinisation within the oceanic crust (Schmidt and Poli, 1998). $F_{\text {serp }}$, presumed to be initially negligent (i.e. $F_{\text {serp }}=0$ for $t<-2300$ ), continuously increased towards the estimated modern value $\left(F_{\text {serp }}(0)=\right.$ $20 * 10^{+18} \mathrm{~mol} \mathrm{H}_{2} \mathrm{O} \mathrm{Ma}{ }^{-1}$; cf. Wallmann, 2001) following the equation:

$F_{\text {serp }}=F_{\text {serp }}(0) *\left[1-\frac{t}{(-2300)}\right]$
Most serpentinisation is assumed to occur in the deeper oceanic crust (70\%), with the remainder (30\%) attributed to the upper crust.

5.1.3.2. Mantle water ${ }^{18} \mathrm{O}$ mole fraction, $\Phi_{m}$. In the standard run, ${ }^{18} \mathrm{O}$ mole fraction in mantle water was kept constant in order to maintain an invariable mantle water $\delta^{18} \mathrm{O}\left(\delta^{18} \mathrm{O}_{\mathrm{m}}\right)$. Meanwhile, an additional model was set up to investigate the influence of initially lower $\Phi_{\mathrm{m}}$ and $\delta^{18} \mathrm{O}_{\mathrm{m}}$. The initial $\Phi_{\mathrm{m}}$ was lowered until an initial value of about $0 \%$ was obtained for $\delta^{18} \mathrm{O}_{\mathrm{m}}$. This was achieved using the following equations:

$\Phi_{\mathrm{mi}}-0.000013 *\left[\frac{t}{(-3420.51)}\right]^{4}$

where the modern mantle ${ }^{18} \mathrm{O}$ mole fraction $\left(\Phi_{\mathrm{mi}}\right)$ is 0.002015 .

\subsection{Modelling outcomes}

Only calcite from bulk rock and brachiopods was used in the model because the temperature equation in Section 5.1.2 only applies to calcite. This will not have had a significant impact on the model outcome since dolomite essentially displays the same trend as calcite (Figs. 4, 10). Calcite $\delta^{18} \mathrm{O}$ underwent exponential smoothing (see Section 3.3) in order to use it as input data to determine the evolution of temperature over time.

The final result of the $\delta^{18} \mathrm{O}$ modelling is shown in Fig. 14. Calcite $\delta^{18} \mathrm{O}$ changes from $-16 \%$ opDB to $0 \%$ орDB 
Table 7

Constant parameter values used in the definition of model fluxes

\begin{tabular}{|c|c|}
\hline Parameter & Symbol/value \\
\hline $\begin{array}{l}\text { Current } \mathrm{H}_{2} \mathrm{O} \text { fixation in } \\
\text { weathering products }\end{array}$ & $F_{\mathrm{w}}(0)=7 * 10^{+18} \mathrm{~mol} \mathrm{Myr}^{-1}$ \\
\hline $\begin{array}{l}\text { Current } \mathrm{H}_{2} \mathrm{O} \text { fixation in } \\
\text { upper crust }\end{array}$ & $F_{\text {alt }}(0)=6 * 10^{+18} \mathrm{~mol} \mathrm{Myr}^{-1}$ \\
\hline $\begin{array}{l}\text { Current } \mathrm{H}_{2} \mathrm{O} \text { fixation in } \\
\text { deep crust }\end{array}$ & $F_{\mathrm{sp}}(0)=20 * 10^{+18} \mathrm{~mol} \mathrm{Myr}^{-1}$ \\
\hline $\begin{array}{l}\text { Current } \mathrm{H}_{2} \mathrm{O} \text { fixation in } \\
\text { serpentinite }\end{array}$ & $F_{\text {serp }}(0)=20 * 10^{+18} \mathrm{~mol} \mathrm{Myr}^{-1}$ \\
\hline $\begin{array}{l}\text { Current } \mathrm{H}_{2} \mathrm{O} \text { release from } \\
\text { the mantle }\end{array}$ & $F_{m}(0)_{\mathrm{c}}=3 * 10^{+18} \mathrm{~mol} \mathrm{Myr}^{-1}$ \\
\hline $\begin{array}{l}\text { Current production of } \\
\text { sedimentary rock oxygen }\end{array}$ & $F_{\mathrm{ps}}(0)=7.8^{*} 10^{+19} \mathrm{~mol} \mathrm{Myr}^{-1}$ \\
\hline $\begin{array}{l}\text { Current production of } \\
\text { upper crust oxygen }\end{array}$ & $F_{\text {pup }}(0)=1.2 * 10^{+20} \mathrm{~mol} \mathrm{Myr}^{-1}$ \\
\hline $\begin{array}{l}\text { Current production of } \\
\text { deep crust oxygen }\end{array}$ & $F_{\text {pdeep }}(0)=1.6^{*} 10^{+21} \mathrm{~mol} \mathrm{Myr}^{-1}$ \\
\hline $\begin{array}{l}\text { Current }{ }^{18} \mathrm{O} \text { loss during } \\
\text { turnover of porewater }\end{array}$ & $F_{\mathrm{pw}}^{18}(0)=2 * 10^{+14} \mathrm{~mol} \mathrm{Myr}^{-1}$ \\
\hline $\begin{array}{l}\text { Fraction of recycled } \\
\text { sedimentary rock } \mathrm{H}_{2} \mathrm{O}\end{array}$ & $r_{\mathrm{w}}=1$ \\
\hline $\begin{array}{l}\text { Fraction of recycled } \\
\text { upper crust } \mathrm{H}_{2} \mathrm{O}\end{array}$ & $r_{\mathrm{up}}=1$ \\
\hline $\begin{array}{l}\text { Fraction of recycled } \\
\text { deep crust } \mathrm{H}_{2} \mathrm{O}\end{array}$ & $r_{\text {deep }}=0.5$ \\
\hline $\begin{array}{l}\text { Fraction of serpentinisation } \\
\text { occuring at low temperatures } \\
\text { in upper crust }\end{array}$ & $\mathrm{r}_{\text {serp }}=0.3$ \\
\hline $\begin{array}{l}\text { Isotopic fractionation factor } \\
\text { for } \mathrm{H}_{2} \mathrm{O} \text { uptake in clays }\end{array}$ & $\alpha_{\mathrm{w}}=1.022$ \\
\hline $\begin{array}{l}\text { Isotopic fractionation factor } \\
\text { for } \mathrm{H}_{2} \mathrm{O} \text { uptake in upper }\end{array}$ & $\alpha_{\text {up }}=1.02$ \\
\hline $\begin{array}{l}\text { Isotopic fractionation factor } \\
\text { for } \mathrm{H}_{2} \mathrm{O} \text { uptake in deep crust }\end{array}$ & $\alpha_{\text {deep }}=1$ \\
\hline $\begin{array}{l}{ }^{18} \mathrm{O} \text { mole fraction in } \\
\text { weathering silicate rocks }\end{array}$ & $\Phi_{\mathrm{si}}=2.017^{*} 10^{-3}$ \\
\hline${ }^{18} \mathrm{O}$ mole fraction in fresh crust & $\Phi_{\mathrm{oc}}=2.0126 * 10^{-3}$ \\
\hline${ }^{18} \mathrm{O}$ fraction in mantle water & $\Phi_{\mathrm{m}}=2.015^{*} 10^{-3}$ \\
\hline $\begin{array}{l}\text { Mass of oxygen in } \\
\text { sedimentary rocks }\end{array}$ & $M_{\mathrm{w}}=7 * 10^{+22} \mathrm{~mol} \mathrm{Myr}^{-1}$ \\
\hline $\begin{array}{l}\text { Mass of oxygen in upper } \\
\text { crust }(0-0.5 \mathrm{~km})\end{array}$ & $M_{\mathrm{up}}=1.0 * 10^{+22} \mathrm{~mol} \mathrm{Myr}^{-1}$ \\
\hline Mass of oxygen in deep crust & $M_{\text {deep }}=1.6^{*} 10^{+23} \mathrm{~mol} \mathrm{Myr}^{-1}$ \\
\hline
\end{tabular}

over the last 3.4 billion years in the model whereas seawater $\delta^{18} \mathrm{O}$ increases from $-13.3 \%{ }_{\text {SMOw }}$ to the modern value of $-0.3 \%{ }_{\text {sMow }}$ over the same time period. Similarly, seawater $\delta^{18} \mathrm{O}$ increased from $-11.8 \%$ osmow in the Archean to $-5 \%$ smow in the Early Palaeozoic to $-2 \%{ }_{\text {SMOw }}$ by the Mesozoic in a more conservative model run, in which bulk rock calcite has been shifted upwards by $2 \%$ to take into account postdepositional alteration towards lower values. The $\delta^{18} \mathrm{O}$ values for the ancient ocean agree with suggested values published by scientists in favour of a changeable seawater $\delta^{18}$ O (Perry, 1967; Walker and Lohmann, 1989). According to the model, the average rate of change in
Table 8

Time-dependent model variables

\begin{tabular}{ll}
\hline Variable & Symbol/equation \\
\hline${ }^{18} \mathrm{O}$ mole fraction in free water & $\Phi_{\mathrm{f}}=\frac{M_{f}^{18}}{M_{f}}$ \\
${ }^{18} \mathrm{O}$ mole fraction in sedimentary rocks & $\Phi_{\mathrm{w}}=\frac{M_{w}^{18}}{M_{w}}$ \\
${ }^{18} \mathrm{O}$ mole fraction in upper crust & $\Phi_{\mathrm{up}}=\frac{M_{u p}^{18}}{M_{u p}}$ \\
${ }^{18} \mathrm{O}$ mole fraction in deep crust & $\Phi_{\mathrm{deep}}=\frac{M_{\mathrm{deep}}^{18}}{M_{\mathrm{deep}}}$ \\
between deep crust and seawater & $R=\frac{\Phi}{1-\Phi}$ \\
$\begin{array}{l}\text { Corresponding }{ }^{18} \mathrm{O} /{ }^{16} \mathrm{O} \text { ratios } \\
\text { Isotopic saturation index for }{ }^{18} \mathrm{O} \text { exchange } \\
\text { between upper crust and seawater } \\
\text { exchange during silicate weathering }\end{array}$ & $\Omega_{\mathrm{deep}}=\frac{R_{\mathrm{oc}} / R_{\mathrm{f}}}{\alpha_{\mathrm{deep}}}$ \\
& $\Omega_{\mathrm{wp}}=\frac{R_{\mathrm{si}} / R_{\mathrm{f}}}{\alpha_{\mathrm{w}}}$ \\
$\alpha_{\mathrm{up}}$ & \\
&
\end{tabular}

seawater $\delta^{18} \mathrm{O}$ amounted to $0.38 \%$ per $10^{8}$ years over the last $3.4 \mathrm{Ga}(0.34 \%$ in the conservative scenario). The highest average rate of change occurred over the last $500 \mathrm{Ma}$ with $\delta^{18} \mathrm{O}$ increasing at $1.2 \%$ every $10^{8}$ years. These variations are consistent with published values of

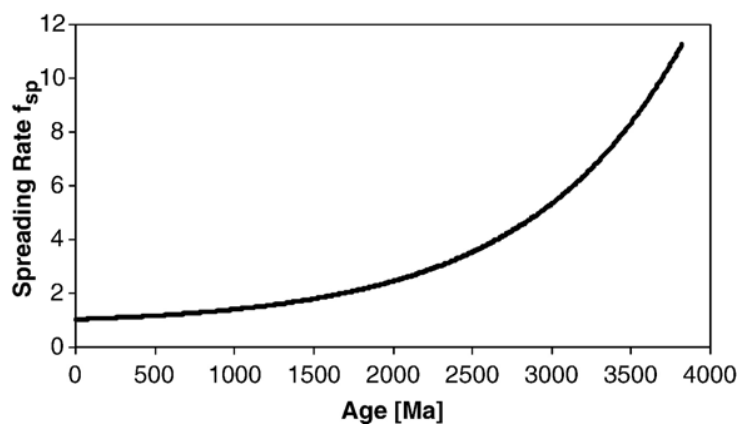

Fig. 12. Spreading rate compared to modern rate. The nondimensional tectonic/volcanic activity $\left(f_{\mathrm{sp}}\right)$ is taken to be proportional to the square of heat loss (Phipps Morgan, 1998). 


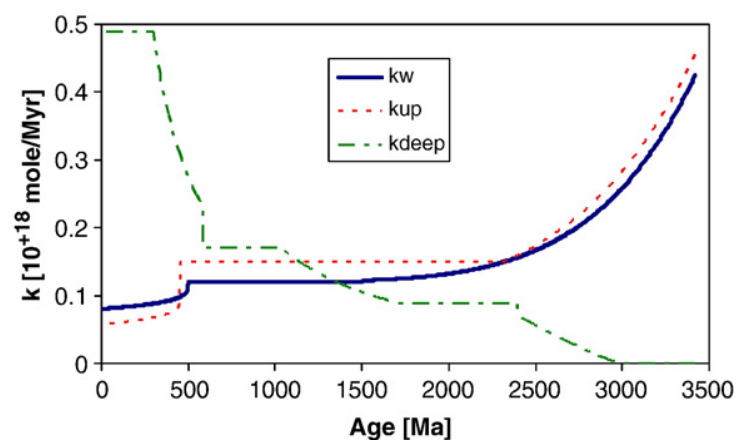

Fig. 13. Changes in kinetic constants, which define the intensity of isotopic exchange processes associated with continental silicate weathering $\left(k_{\mathrm{w}}\right)$ as well as low- and high-temperature seawater/rock interactions at the seafloor $\left(k_{\text {up }}, k_{\text {deep }}\right)$.

around $1.0 \% \mathrm{o} / 10^{8}$ years derived from some geochemical models (Walker and Lohmann, 1989; Gregory, 1991). Seawater $\delta^{18} \mathrm{O}$ closely follows calcite $\delta^{18} \mathrm{O}$ over time, leading to temperatures generally between $10{ }^{\circ} \mathrm{C}$ and $32^{\circ} \mathrm{C}$ (Fig. 15). This temperature range therefore lies within the estimated likely maximum sea surface values of about $34^{\circ} \mathrm{C}$ and the lower lethal limit of about $10{ }^{\circ} \mathrm{C}$ for tropical, subtidal shelf marine species (Newell and Dopplick, 1979; Thompson and Newton, 1988; see also Section 4.3.1).

The $\delta^{18} \mathrm{O}$ of the mantle water was kept close to the modern value of about 7\%o (Fig. 16; Shanks et al., 1995: Fig. 2). The $\delta^{18} \mathrm{O}$ of the deep crust remained constant at around $5 \%\left( \pm 0.5 \%\right.$ ) whereas the $\delta^{18} \mathrm{O}$ of the upper crust varied between $7 \%$ and $11 \%$ o (between $9.4 \%$ and $11.5 \%$ in the conservative scenario). The average $\delta^{18} \mathrm{O}$ of clay increased from $10 \%$ to $15 \%$ over time.

The mass of free water initially increased from $5.4 * 10^{+22}$ mol to about $9.1 * 10^{+22}$ mol between 3.8 and 1.7 billion years ago and subsequently decreased to the modern level of about $8.1 * 10^{+22} \mathrm{~mol}$ (Fig. 17). This change was induced by variable mantle water emission

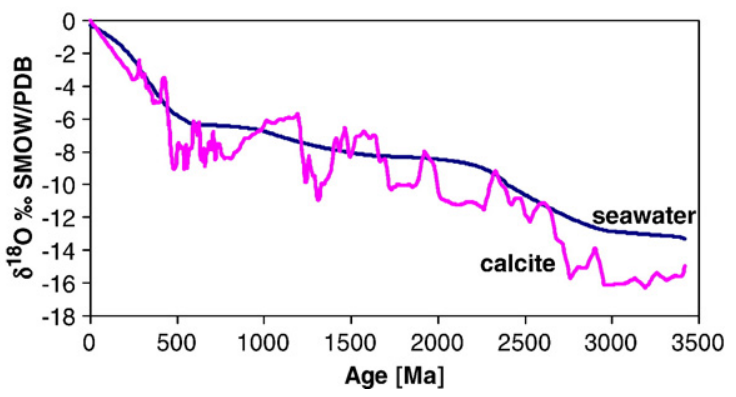

Fig. 14. Variation of marine calcite and modelled seawater $\delta^{18} \mathrm{O}$ over the last $3400 \mathrm{Ma}$. The marine calcite $\delta^{18} \mathrm{O}$ values underwent exponential smoothing using Holt's method, which assumes that the data have a linear trend and no seasonal variation.

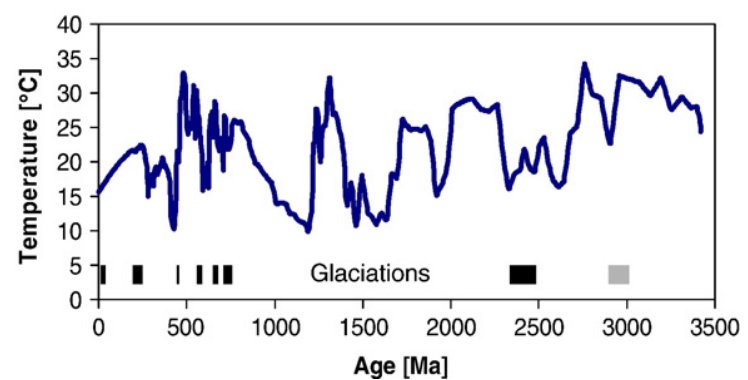

Fig. 15. Model result for temperature evolution over the last $3400 \mathrm{Ma}$. The temperature was derived from the difference between calcite $\delta^{18} \mathrm{O}$ and modelled seawater $\delta^{18} \mathrm{O}$. The film strip is displaying glacial episodes (black: confirmed cool periods; grey: possible glaciation at $2.9 \mathrm{Ga}$ ). Model results for conservative scenario are not shown but yield similar temperature estimates.

into the ocean $\left(F_{m}(0)\right.$ decreasing from $15^{*} 10^{+18} \mathrm{~mol} / \mathrm{Myr}$ to $3 * 10^{+18} \mathrm{~mol} / \mathrm{Myr}$ ). Without the initial increase in water emission, all free water would have rapidly (within $1.0 \mathrm{Ga}$ ) been stored in rocks, depleting the ocean reservoir and, thus, preventing any interaction between crust and the ocean.

\subsubsection{Impact of parameters on seawater $\delta^{18} \mathrm{O}$}

5.2.1.1. Kinetic parameters. The rise towards heavier seawater $\delta^{18} \mathrm{O}$ equilibria is achieved via increasing the kinetic parameter that defines the exchange of ${ }^{18} \mathrm{O}$ between lower crust and seawater $\left(k_{\text {deep }}\right)$, i.e. increasing the importance of high-temperature alteration, and concomitantly decreasing $k_{\text {up }}$ (kinetic parameter that defines the uptake of ${ }^{18} \mathrm{O}$ in upper crust through isotopic exchange with seawater), and $k_{\mathrm{w}}$ (defines the exchange of ${ }^{18} \mathrm{O}$ during silicate weathering).

In many studies (Knauth and Epstein, 1976; Knauth and Lowe, 1978; Karhu and Epstein, 1986), very high paleotemperatures $\left(>50{ }^{\circ} \mathrm{C}\right)$ were obtained because it was assumed that seawater $\delta^{18} \mathrm{O}$ was buffered at the modern value of around $0 \%$. In order to investigate how

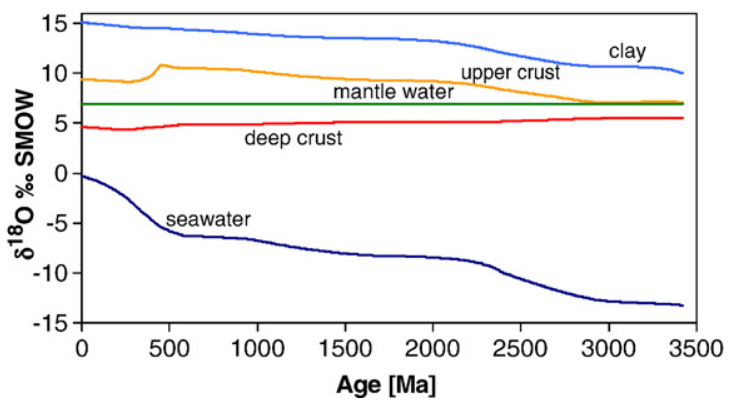

Fig. 16. Model outcome for $\delta^{18} \mathrm{O}$ variation of seawater, upper and lower crust, clay and mantle water over the last $3400 \mathrm{Ma}$. 


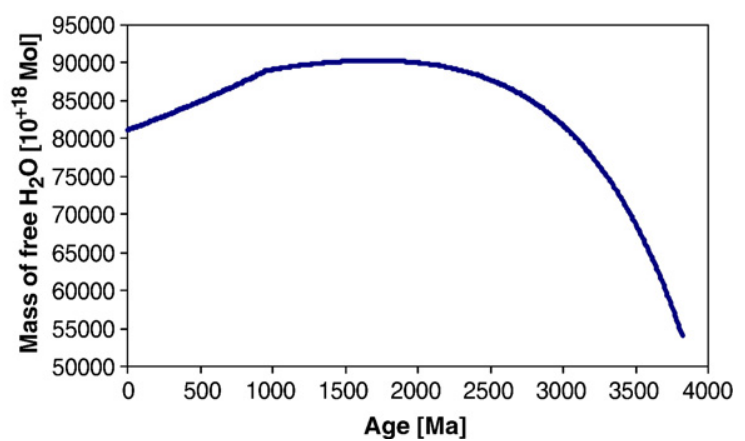

Fig. 17. Model result for change in free water over the last $3.8 \mathrm{Ga}$.

temperature would evolve if the ocean were buffered to around $0 \%$ throughout geologic time, the kinetic parameters were not allowed to change over time in an additional model. Under this setting, seawater $\delta^{18} \mathrm{O}$, independent of the initial value, would rapidly (within $100 \mathrm{Ma}$ ) approach modern values (around $-0.6 \%$ ). This scenario produces unreasonably high temperatures ( $\geq 60{ }^{\circ} \mathrm{C}$; Fig. 2) that are above the upper temperature limit for Phanerozoic metazoans and Proterozoic eukaryotes such as red algae (Xiao et al., 1997; Kah, 2000; Rothschild and Mancinelli, 2001). Such high temperatures are also incompatible with the occurrence of glacial periods.

5.2.1.2. Serpentinisation. The inclusion of serpentinisation $\left(F_{\text {serp }}\right)$ in additional models does not have a significant impact on seawater $\delta^{18} \mathrm{O}$ since it does not equilibrate silicate minerals with the ocean. A slight increase in seawater $\delta^{18} \mathrm{O}$ would have been induced (e.g. modern seawater $\delta^{18} \mathrm{O}$ value of $0.03 \%$ as opposed to $-0.29 \%$ ) without correction of the initial amount of free water towards a higher value $\left(6.2 * 10^{+25}\right.$ mole as opposed to $5.4 * 10^{+25} \mathrm{~mol}$ ) to obtain the correct final quantity due to the increased amount of water storage via serpentinisation. After the free water correction, the modern seawater $\delta^{18} \mathrm{O}$ was lowered to $-0.32 \%$.

5.2.1.3. Isotopic fractionation coefficients, $\alpha$. The isotopic fractionation coefficient for $\mathrm{H}_{2}^{18} \mathrm{O}$ uptake in upper crust at low temperatures $\left(\alpha_{\text {up }}\right)$ and at high temperatures in deeper crust $\left(\alpha_{\text {deep }}\right)$ as well as the isotopic fractionation coefficient for silicate weathering $\left(\alpha_{\mathrm{w}}\right)$ have a significant impact on seawater $\delta^{18} \mathrm{O}$. Since isotopic fractionation decreases with increasing temperature (Silverman, 1951; Friedman and O'Neil, 1977; Holmden and Muehlenbachs, 1993a; Frank and Lyons, 2000), $\alpha_{\text {deep }}$ was assumed to be equal to 1.0. Both $\alpha_{\mathrm{up}}$ and $\alpha_{\mathrm{w}}$ are greater than 1.0 since these fractionations relate to alteration at lower temperatures. When both $\alpha_{\text {up }}$ (from 1.02 to 1.015 ) and $\alpha_{\mathrm{w}}$ (from 1.022 to 1.02 ) were decreased in the model, seawater $\delta^{18} \mathrm{O}$ increased significantly compared to the standard model (Fig. 18). In other words, an increase in the temperature of low-temperature alteration resulted in a lower isotopic fractionation coefficient. Conversely, a decrease in seawater $\delta^{18} \mathrm{O}$ could be achieved by lowering temperatures (higher isotopic fractionation coefficients) or by a greater proportion of low-temperature alteration compared to high-temperature alteration processes.

\section{Consequences for Earth system evolution}

\subsection{High-versus low-temperature alteration}

The ratio of high- to low temperature alteration determines the evolution of seawater $\delta^{18} \mathrm{O}$. Seawater $\delta^{18} \mathrm{O}$ will reach a stable equilibrium if the ratio is not changed. This means that, for example, a rise in hightemperature alteration does not necessarily lead to an increase in seawater $\delta^{18} \mathrm{O}$ if low-temperature alteration is increased to the same extent. If only high-temperature alteration is increased, an increase in seawater $\delta^{18} \mathrm{O}$ would result until a new equilibrium is reached.

To maintain an initially low seawater $\delta^{18} \mathrm{O}$, it is necessary to have negligible high-temperature alteration, or almost total overprinting of high-temperature by low temperature alteration, over that period, as the presence of high-temperature alteration would inevitably lead to an increase in seawater $\delta^{18} \mathrm{O}$ if low-temperature alteration were not increased disproportionately (Muehlenbachs and Clayton, 1976; Holland, 1984, pp. 242; Veizer et al., 1986; Walker and Lohmann, 1989; Qing and Veizer, 1994; JeanBaptiste et al., 1997; Muehlenbachs, 1998; Lécuyer and Allemand, 1999). It was therefore assumed that practically

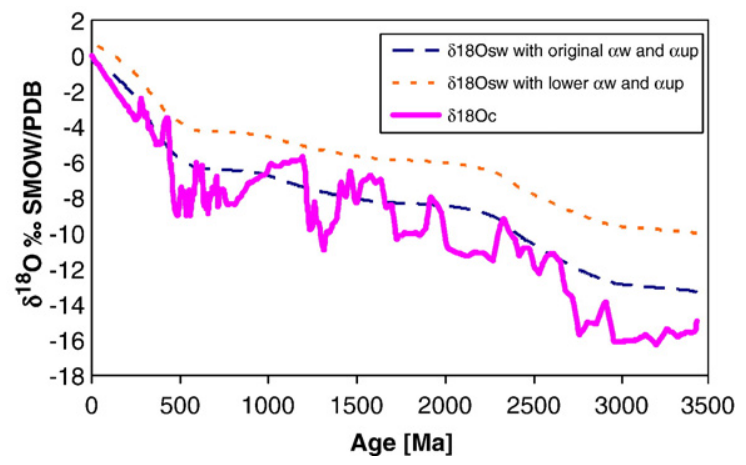

Fig. 18. Model result for $\delta^{18} \mathrm{O}$ variation of seawater $\left(\delta^{18} \mathrm{O}_{\mathrm{sw}}\right)$ over the last $3400 \mathrm{Ma}$. The change in seawater $\delta^{18} \mathrm{O}$ is displayed for both isotopic fractionation coefficients $\left(\alpha_{\mathrm{up}}\right.$ and $\left.\alpha_{\mathrm{w}}\right)$ of the standard case (dashed line) and of the additional model (dotted line). The change in calcite $\delta^{18} \mathrm{O}$ $\left(\delta^{18} \mathrm{O}_{\mathrm{c}}\right.$, solid line) is also shown. 
all alteration initially takes place at low temperatures (i.e. higher $k_{\text {up }}$ and $k_{\mathrm{w}}$ ) while high-temperature alteration is initially shut down (initial $k_{\text {deep }}=0 ; k_{\text {deep }}=0.1$ for the more conservative scenario), agreeing with suggestions that the ratio of high- versus low-temperature processes may have changed through time (Veizer et al., 1986; Lécuyer and Allemand, 1999). The initial seawater $\delta^{18} \mathrm{O}$ value of about $-13.3 \%$ of our model lies within the range of $-15 \%$ to $+4 \%$ inferred from a model based on ophiolite data and variable prevalence of low-versus high-temperature processes (Walker and Lohmann, 1989). Similarly, applying a more conservative scenario such as adding $2 \%$ to the bulk rock $\delta^{18} \mathrm{O}$, or using early marine cement data only, would give $\delta^{18} \mathrm{O}$ values that lie within the estimated range above, the only difference being that the ratio of high- to lowtemperature would vary from one scenario to another. The following sections will outline how the increase in seawater $\delta^{18} \mathrm{O}$ was achieved via variable low- or hightemperature alteration prevalence.

\subsubsection{Sea level}

A relative decrease in high-temperature alteration can be attained by subaerial exposure of fresh basalt, which is either achieved by shallower oceans or by higher midocean ridges (Walker and Lohmann, 1989). In the present model, the sea level was initially lower than today due to a lower mass of free water $\left(7 * 10^{+22}\right.$ mol about 3.8 billion years ago; see Fig. 17). Additionally, a shallower ocean would have existed before the development of stable continental shelves (Walker and Lohmann, 1989; Kasting et al., 2006). This would have resulted in diminished hydrothermal alteration since more rock was subaerially exposed. A shallower ocean would also have reduced the pressure within the hydrothermal system (Kasting et al., 2006). Consequently, hydrothermal circulation would have penetrated less deeply and been of a lesser intensity, therefore reducing the importance of high-temperature relative to low-temperature alteration. Walker and Lohmann (1989) suggested that a shallower ocean with subaerially exposed mid-ocean ridges would lead to the elimination of Earth's internal heat by subaerial cooling only, in the absence of any hydrothermal influence. As sea levels rose, covering the subaerially exposed flanks of mid-ocean ridges, high-temperature alteration gradually increased to current rates. Kasting et al. (2006) proposed that a critical mean ridge crest $(2.4 \mathrm{~km})$ exists, which, if exceeded, would result in significantly larger hightemperature alteration rates due to more efficient hydrothermal circulation. It was suggested that, due to increasing sea levels over time, this critical mean ridge crest was reached at around $500 \mathrm{Ma}$, contributing to the more rapid increase in seawater $\delta^{18} \mathrm{O}$ (Fig. 14).

\subsubsection{Variability in rock-type dominance}

The type of rock undergoing alteration can have a significant influence on the weathering rate because not all rocks display the same susceptibility to chemical weathering (Amiotte Suchet and Probst, 1993). Basalts, which would have been well represented in Archean greenstone belts, for example, are far more easily weathered than other crystalline silicates (Amiotte Suchet and Probst, 1993). The presence of vast greenstone belts in the Archean (2.54.0 Ga, De Wit, 1998), along with theoretically higher $p \mathrm{CO}_{2}$ concentrations in the atmosphere (Kasting, 1987; Des Marais, 1994), would thus be consistent with elevated continental weathering rates (higher $k_{\mathrm{w}}$ ), therefore increasing the relative importance of low-temperature alteration and allowing seawater $\delta^{18} \mathrm{O}$ to stabilise at a more negative value. High chemical weathering rates could be sustained because of high rates of mantle degassing (Barley et al., 2005), which partially resulted from faster spreading rates in the Precambrian (Thurston, 1994).

\subsubsection{Impact of biotic evolution and chemical weathering rates}

In an additional model run, we investigated how changes in continental weathering rates might affect seawater $\delta^{18} \mathrm{O}$ to take into account peaks in chemical weathering rates during the Phanerozoic related to tectonic upheavals and biotic evolution. The introduction of vascular land plants, which is expected to have accelerated weathering since about $350 \mathrm{Ma}$ (Lenton, 2001), appears to have had no noticeable effect on seawater $\delta^{18} \mathrm{O}$ - instead of decreasing, marine carbonate, and presumably seawater $\delta^{18} \mathrm{O}$, has actually increased since then, albeit less steeply than prior to that time. Overall, a doubling of the continental weathering rate over the last $300 \mathrm{Ma}$ would lead to modern seawater $\delta^{18} \mathrm{O}$ values that are about $1 \%$ lower than those of the main run. These results support the widely held notion that absolute continental weathering rates are limited strongly by $\mathrm{CO}_{2}$ outgassing (Walker et al., 1981), whereby short-term increases in weathering efficiency, brought on by biotic evolution, are compensated for over the long-term by lower atmospheric $p \mathrm{CO}_{2}$ (Lenton, 2001).

In addition, the introduction of eukaryotic soil biota (such as algal-fungal symbioses or lichens) close to the Proterozoic-Phanerozoic transition is predicted to have increased not only weathering rates but also clay mineral production (Kennedy et al., 2006), further fractionating oxygen isotopes. This effect may have helped to cause the peak in chemical weathering rates, judged from $\mathrm{Sr}$ isotopes, during the Late Cambrian Period (Shields and Veizer, 2002), which does indeed coincide with minimum carbonate $\delta^{18} \mathrm{O}$ values. If there is a genuine connection 
between the apparent $\delta^{18} \mathrm{O}$ minimum and the ${ }^{87} \mathrm{Sr} /{ }^{86} \mathrm{Sr}$ maximum around $500 \mathrm{Ma}$, then its effect was both shortlived and reversible as carbonate $\delta^{18} \mathrm{O}$ values have increased rather than decreased since that time. This agrees with our experiment, in which the continental weathering rate was doubled between $650-450 \mathrm{Ma}$, with no significant effect on seawater $\delta^{18} \mathrm{O}$. These experiments support our notion and the consensus opinion that the influence of continental weathering is subordinate to submarine alteration during the Phanerozoic at least.

\subsubsection{Upper crust permeability}

Conversely, a relative decrease in low-temperature alteration is achieved via formation of thick sedimentary blankets over fresh crystalline rocks, thus reducing the interaction between seawater and the crust (Walker and Lohmann, 1989; Lécuyer and Allemand, 1999; Wallmann, 2004). Since siliceous and carbonate sediment production in the pelagic environment only took off after the appearance of shell-secreting organisms close to the Precambrian/Cambrian boundary about 550 Myrs ago, the initially low sediment cover would have led to greater low-temperature hydrothermal alteration and exchange with seawater at the ridge flanks in the Precambrian and subsequent rapid decrease in alteration (lower $k_{\text {up }}$ ) due to the formation of the sediment blanket. This process would have led to a relative and absolute reduction of low-temperature alteration compared to high-temperature processes. Therefore, a more rapid increase in seawater $\delta^{18} \mathrm{O}$ could be expected in the last $500 \mathrm{Ma}$, which is reflected in our model (Fig. 14), but surprisingly no major change in carbonate $\delta^{18} \mathrm{O}$ is observed since the evolution of planktic calcifiers during the Meosozoic era.

The permeability of the upper crust also depends on the prevailing spreading rate, with high spreading rates resulting in the formation of more highly permeable crust than at slow-spreading ridges (Fornari and Embley, 1995). Therefore, hydrothermal circulation is enhanced at fast spreading ridges (Fornari and Embley, 1995). Since it is assumed that spreading rates were faster in the Precambrian (Fig. 12), the resultant more permeable upper crust would have resulted in increased hydrothermal alteration at both low- and high-temperatures. However, because the effect of high-temperature alteration on seawater $\delta^{18} \mathrm{O}$ would have been reduced due to low sea level during the Archean (see earlier discussion), the faster spreading rates of those times would have led to lower seawater $\delta^{18} \mathrm{O}$.

\subsubsection{Upper ocean crust and ophiolites}

Over the last $2.0 \mathrm{Ga}$, upper crust $\delta^{18} \mathrm{O}$ has remained rather constant in the model, the $\delta^{18} \mathrm{O}$ varying between
9.4\% and $10.7 \%$, while seawater $\delta^{18} \mathrm{O}$ increased from $-8 \%$ to $-0.3 \%$ over the same period. Even 3.4 Ga years ago, when seawater $\delta^{18} \mathrm{O}$ was modelled as being about $-13.3 \%$, the $\delta^{18} \mathrm{O}$ of the upper crust never decreased below 7.1\%. These findings contradict claims (Holmden and Muehlenbachs, 1993a) that low seawater $\delta^{18} \mathrm{O}$ will necessarily also lead to lower ophiolite $\delta^{18} \mathrm{O}$. The results of this model show that, while seawater $\delta^{18} \mathrm{O}$ was initially much lower, this does not necessarily have to be reflected in the ophiolite $\delta^{18} \mathrm{O}$ record originally derived from the ocean crust. Thus, an ocean of lower $\delta^{18} \mathrm{O}$ does not conflict with invariable ophiolite $\delta^{18} \mathrm{O}$, and can, therefore, not be used as a definitive argument against changing seawater $\delta^{18} \mathrm{O}$.

In the model, a concurrent increase in both upper crust $\delta^{18} \mathrm{O}\left(\delta^{18} \mathrm{O}_{\text {up }}\right)$ and seawater $\delta^{18} \mathrm{O}$ is noted until $500 \mathrm{Ma}$ (Fig. 16). The small increase in $\delta^{18} \mathrm{O}_{\text {up }}$ over time could be interpreted as the result of a variable thickness of upper crust being affected by low-temperature alteration. Since the thickness of the upper crust (500 m) was kept constant in the model, the increase in $\delta^{18} \mathrm{O}_{\text {up }}$ could be a sign of an initially thicker upper crust. Such a deepening of the upper ${ }^{18} \mathrm{O}$-enriched crust could explain the initial depletion of seawater $\delta^{18} \mathrm{O}$. Similarly, the decrease of upper crustal $\delta^{18} \mathrm{O}$ during coeval seawater $\delta^{18} \mathrm{O}$ increase in the last $500 \mathrm{Ma}$, could be due to reduced thickness of the upper crust. Ophiolite studies indeed show that the thickness of the upper 180-enriched crust varied over time (Gregory and Taylor, 1981; Alt et al., 1995). Alternatively, the decrease in the upper crust $\delta^{18} \mathrm{O}$ could be linked to low-temperature alteration occurring at higher temperatures.

\subsection{Paleoclimate reconstructions}

Since both marine carbonate $\delta^{18} \mathrm{O}$ values and their ages had to be smoothed in order to model them, the derived temperatures became more inaccurate. It was therefore assumed that the effects of warm and cold climate on the $\delta^{18} \mathrm{O}$ record would be partially removed or shifted. Nevertheless, periods of minimum temperatures correlate surprisingly well with known ice ages of both the Phanerozoic and the Neoproterozoic (Fig. 15). For example, a shift towards higher maximum $\delta^{18} \mathrm{O}$ values is observed in Geon 6 and 7 samples, coinciding with the Neoproterozoic glaciations at $750-580 \mathrm{Ma}$ (Condon et al., 2005). Higher maximum $\delta^{18} \mathrm{O}$ values were also recorded for 2.3-2.4 Ga, the period of early Proterozoic glaciations. The paleotemperatures $\left(10-32{ }^{\circ} \mathrm{C}\right)$ obtained in this study stand in marked contrast to previously published estimates, in which temperatures exceeding $60^{\circ} \mathrm{C}$ were proposed for the Precambrian (e.g. Knauth and Epstein, 1976; Knauth 
and Lowe, 1978; Karhu and Epstein, 1986; Robert and Chaussidon, 2006).

\section{Conclusions}

Even though a lot of research has been conducted in the field of seawater $\delta^{18} \mathrm{O}$ during the last 50 years, there is still no consensus as to whether seawater $\delta^{18} \mathrm{O}$ was and is currently buffered to about $0 \pm 1 \%$ or whether it has changed over time. An invariant (buffered) ocean, however, seems to be unlikely considering the good correlation between detrended carbonate $\delta^{18} \mathrm{O}$ values and paleoclimate. Therefore, it is not only considered that the trend of decreasing $\delta^{18} \mathrm{O}$ with age is a primary feature but also that seawater $\delta^{18} \mathrm{O}$ is changeable beyond the ice-volume effect. The results of the present model support these conclusions, the model showing not only that most of the carbonate $\delta^{18} \mathrm{O}$ trend can be explained by variations in seawater $\delta^{18} \mathrm{O}$, but also that the deviations from that trend result in plausible seawater temperatures $\left(10-33^{\circ} \mathrm{C}\right)$. The upper crust remains rather constant $(7.1-10.7 \%$ ) in the model throughout geological time, indicating that the absence of a $\delta^{18} \mathrm{O}$ trend in ophiolite samples does not conflict with changing seawater $\delta^{18} \mathrm{O}$. To what extent $\mathrm{pH}$ influences carbonate $\delta^{18} \mathrm{O}$ was not investigated in the present model but it was concluded that its influence would be relatively small, restricted to specific time intervals only and cannot explain the entire carbonate $\delta^{18} \mathrm{O}$ trend.

The increase in marine carbonate $\delta^{18} \mathrm{O}$ is interpreted as being mainly a primary trend caused by tectonic processes, with superimposed fluctuations triggered by climatic parameters. The strong ${ }^{18} \mathrm{O}$-depletion in Precambrian seawater resulted from enhanced weathering (induced by higher $p \mathrm{CO}_{2}$ levels, emergent spreading ridges and the presence of more easily weathered rocks such as greenstones) as well as the diminished impact of hightemperature alteration on seawater $\delta^{18} \mathrm{O}$ (due to low sea level). As the amount of free water increased due to the initially very high rate of degassing, high-temperature alteration became more important (both absolute and relative to low-temperature alteration), thus leading to a steady increase in seawater $\delta^{18} \mathrm{O}$ between 3.0 and $2.3 \mathrm{Ga}$ once the mid-ocean ridges were no longer subaerially exposed. The more recent and more rapid increase in seawater $\delta^{18} \mathrm{O}$ (at about $500 \mathrm{Ma}$ ) coincided with the rapid evolution of shell organisms, resulting in a thick sediment cover, which inhibited the interaction between oceanic crust and the ocean. Therefore, the relative and absolute effect of low-temperature alteration was reduced, causing the rapid increase in seawater $\delta^{18} \mathrm{O}$ towards the present value of about $-0.3 \%$.
There are several major research aspects that require further investigation. Few workers have, so far, tried to assess the robustness of Precambrian $\delta^{18} \mathrm{O}$ by considering data in a rigorous context of regional depositional facies patterns, and potential diagenetic and metamorphic overprints on primary $\delta^{18} \mathrm{O}$. Careful (re-)evaluation of oxygen isotope data against the context of their depositional setting may reveal the origin and significance of $\delta^{18} \mathrm{O}$ patterns found in sediment and fossil samples. The relative influence of diagenesis on whole rock versus brachiopod $\delta^{18} \mathrm{O}$ composition should also be investigated more thoroughly. Analysis of the influence of higher $\mathrm{pCO}_{2}$ on continental weathering and seawater $\delta^{18} \mathrm{O}$, and the effect of changing carbonate equilibrium on calcite $\delta^{18} \mathrm{O}$ may further clarify the significance of the $\delta^{18} \mathrm{O}$ trend displayed in samples. Creation of models that include not only carbonate $\delta^{18} \mathrm{O}$, temperature and the various exchange processes with the oceanic crust, but also phosphate $\delta^{18} \mathrm{O}, \mathrm{pH}$ and the ice-volume effect may contribute to a better understanding of the significance of the $\delta^{18} \mathrm{O}$ trend noted in marine samples. Additionally, further research is required in determining the effect of seafloor sediment cover on hydrothermal alteration and seawater $\delta^{18} \mathrm{O}$.

\section{Acknowledgments}

The authors wish to thank all those who have generously supplied their isotopic data for this study. Additional thanks are due to two journal reviewers and editor Anthony Hallam for advice during the review process which helped to strengthen our paper. Graham Shields gratefully acknowledges the financial support of the Alexander von Humboldt Foundation during 2006 and 2007.

\section{References}

Abell, P.I., McClory, J., Martin, A., Nisbet, E.G., Kyser, T.K., 1985. Petrography and stable isotope ratios from Archaean stromatolites, Mushandike Formation, Zimbabwe. Precambrian Res. 27, 385-398.

Al-Aasm, I.S., Veizer, J., 1982. Chemical stabilization of low-Mg calcite: An example of brachiopods. J. Sediment. Petrol. 52, 1101-1109.

Allison, P.A., Briggs, D.E.G., 1993. Paleolatitudinal sampling bias, Phanerozoic species diversity, and the end-Permian extinction. Geology 21, 65-68.

Allison, P.A, Ford, R., Corfield, R., 1998. Stratification and oxygen isotopes in the Paleozoic: is paleothermometry in hot water? Palaeontol. Soc. Spec. Publ. 4, 244-254.

Alt, J.C., Zuleger, E., Erzinger, J., 1995. Mineralogy and stable isotopic composition of the hydrothermally altered lower sheeted dike complex, Hole 504B, Leg 140. Proc. ODP, Sci. Results 137/140, $155-166$. 
Amiotte Suchet, P., Probst, J.L., 1993. Modeling of atmospheric $\mathrm{CO}_{2}$ consumption by chemical weathering of rocks: Application to the Garonne, Congo, and Amazon Basins. Chem. Geol. 107, 205-210.

Anderson, T.F., Bopp, B.N., Williams, A.C., Ho, L.Z., Hudson, J.D., 1994. The stable isotopic records of fossils from the Peterborough member, Oxford clay formation (Jurassic), UK: Palaeoenvironmental implications. J. Geol. Soc. (Lond.) 151, 125-138.

Ayliffe, L.K., Lister, A.M., Chivas, A.R., 1992. The preservation of glacial-interglacial climatic signatures in the oxygen isotopes of elephant skeletal phosphate. Palaeogeogr. Palaeoclimatol. Palaeoecol. 99, 179-191.

Azmy, K., Veizer, J., Bassett, M.G., Copper, P., 1998. Oxygen and carbon isotopic composition of Silurian brachiopods: implications for coeval seawater and glaciations. GSA Bull. 110, 1499-1512.

Baertschi, P., 1957. Messung und Deutung relativer Haufigskeitvariationen von $\mathrm{O}^{18}$ und $\mathrm{C}^{13}$ in Karbonatgesteinen und Mineralien. Schweiz. Mineral. Petrog. Mitt. 37, 73-152.

Banner, J.L., Hanson, G.H., 1990. Calculation of simultaneous isotopic and trace-element variations during water-rock interactions with applications to carbonate diagenesis. Geochim. Cosmochim. Acta 54, 3123-3137.

Barley, M.E., Bekker, A., Krapež, B., 2005. Late Archean to early Paleoproterozoic global tectonics, environmental change and the rise of atmospheric oxygen. Earth Planet. Sci. Lett. 238, 156-171.

Bates, N.R., 1994. Discussion "Early Devonian marine isotopic signatures: brachiopods from the Upper Gaspé limestones, Gaspé Peninsula, Québec, Canada”. J. Sediment. Petrol. A64, 405-407.

Bates, N.R., Brand, U., 1991. Environmental and physiological influences on isotopic and elemental compositions of brachiopod shell calcite: implications for the isotopic evolution of Paleozoic oceans. Chem. Geol. 94, 67-78.

Bau, M., Alexander, B., 2006. Preservation of primary REE patterns without $\mathrm{Ce}$ anomaly during dolomitization of Mid-Paleoproterozoic limestone and the potential re-establishment of marine anoxia immediately after the "Great Oxidation Event". S. Afr. J. Geol. 109 (1-2), 81-86.

Bauld, J., Brock, T.D., 1973. Ecological studies of Chloroflexis, a gliding photosynthetic bacterium. Arch. Microbiol. 92, 267-284.

Becker, R.H., Clayton, R.N., 1976. Oxygen isotope study of a Precambrian banded iron-formation, Hamersley Range, Western Australia. Geochim. Cosmochim. Acta 40, 1153-1165.

Bishop, J.W., Sumner, D.Y, Huerta, N.J., 2006. Molar tooth structures of the Neoarchean Monteville Formation, Transvaal Group, South Africa. II: a wave-induced fluid model. Sedimentology 53, 1069-1082.

Blake, R.E., O’Neil, J.R., Garcia, G.A., 1997. Oxygen isotope systematics of biologically mediated reactions of phosphate: I. Microbial degradation of organophosphorous compounds. Geochim. Cosmochim. Acta 61, 4411-4422.

Blatt, H., 1982. Sedimentary Petrology. W.H. Freeman and Company, New York, p. 564.

Bohrmann, G., Abelmann, A., Gersonde, R., Hubberten, H., Kuhn, G., 1994. Pure siliceous ooze, a diagenetic environment for early chert formation. Geology 22, 207-210.

Bowers, T.S., Taylor, H.P., 1985. An integrated chemical and stable isotope model of the origin of mid-ocean ridge hot spring systems. J. Geophys. Res. 90, 12583-12606.

Brand, U., 1989a. Biogeochemistry of Late Paleozoic North American brachiopods and secular variation of seawater composition. Biogeochem. 7, 159-193.

Brand, U., 1989b. Global climatic changes during the DevonianMississippian: stable isotope biogeochemistry of brachiopods. Palaeogeogr. Palaeoclimatol. Palaeoecol. 75, 311-329.
Brand, U., 2004. Carbon, oxygen and strontium isotopes in Paleozoic carbonate components: an evaluation of original seawater-chemistry proxies. Chem. Geol. 204, 23-44.

Brand, U., Brenckle, P., 2001. Chemostratigraphy of the MidCarboniferous boundary global stratotype section and point (GSSP), Bird Spring Formation, Arrow Canyon, Nevada, USA. Palaeogeogr. Palaeoclimatol. Palaeoecol. 165, 321-347.

Brand, U., Veizer, J., 1980. Chemical diagenesis of a multicomponent carbonate system-1: trace elements. J. Sediment. Res. 50 (4), 1219-1236.

Brand, U., Logan, A., Hiller, N., Richardson, J., 2003. Geochemistry of modern brachiopods: applications and implications for oceanography and paleoceanography. Chem. Geol. 198, 305-334.

Brass, G.W., Southam, J.R., Peterson, W.H., 1982. Warm saline bottom water in the ancient ocean. Nature 296, 620-623.

Brenchley, P.J., Carden, G.A., Hints, L., Kaljo, D., Marshall, J.D., Martma, T., Meidla, T., Nõlvak, J., 2003. High-resolution isotope stratigraphy of Late Ordovician sequences: constraints on the timing of bio-events and environmental changes associated with mass extinction and glaciation. GSA Bull. 115, 89-104.

Brock, T.D., 1985. Life at high temperatures. Science 230, 132-138.

Burdett, J.W., Grotzinger, J.P., Arthur, M.A., 1990. Did major changes in the stable-isotope composition of Proterozoic seawater occur? Geology 18, 227-230.

Caputo, M.V., 1985. Late Devonian Glaciation in South America. Palaeogeogr. Palaeoclimatol. Palaeoecol. 51, 291-317.

Caputo, M.V., Crowell, J.C., 1985. Migration of glacial centers across Gondwana during Paleozoic em. GSA. Bull. 96, 1020-1036.

Carpenter, S.J., Lohmann, K.C., 1995. $\delta^{18} \mathrm{O}$ and $\delta^{13} \mathrm{C}$ values of modern brachiopod shells. Geochim. Cosmochim. Acta 59, 3749-3764.

Carpenter, S.J., Lohmann, K.C., Holden, P., Walter, L.M., Huston, T.J., Halliday, A.N., 1991. $\delta^{18} \mathrm{O},{ }^{87} \mathrm{Sr} /{ }^{86} \mathrm{Sr}$, and $\mathrm{Sr} / \mathrm{Mg}$ ratios of Late Devonian abiotic marine calcite: implications for the composition of ancient seawater. Geochim. Cosmochim. Acta 55, 1991-2010.

Cary, S.C., Shank, T., Stein, J., 1998. Worms bask in extreme temperatures. Nature 391, 545-546.

Charlou, J.L., Donval, J.P., Fouquet, Y., Jean-Baptiste, P., Holm, N., 2002. Geochemistry of high $\mathrm{H}_{2}$ and $\mathrm{CH}_{4}$ vent fluids issuing from ultramafic rocks at the Rainbow hydrothermal field $\left(36^{\circ} 14^{\prime} \mathrm{N}, \mathrm{MAR}\right)$. Chem. Geol. 191, 345-359.

Chase, C.G., Perry, E.C., 1972. The oceans: growth and oxygen isotope evolution. Science 177, 992-994.

Choquette, P.W., James, N.P., 1990. Limestones - the burial diagenetic environment. In: McIlreath, I.A., Morrow, D.W. (Eds.), Diagenesis. Geosci. Can. Repr. Ser., vol. 4, pp. 75-111. Ottawa, Canada.

Condon, D., Zhu, M., Bowring, S., Wang, W., Yang, A., Jin, Y., 2005. $\mathrm{U}-\mathrm{Pb}$ ages from the Neoproterozoic Doushantuo Formation, China. Science 308, 95-98.

Craig, H., Gordon, L.I., 1965. Deuterium and oxygen 18 variations in the ocean and the marine atmosphere. In: Tongiorgo, E. (Ed.), Stable Isotopes in Oceanographic Studies and Paleotemperatures. Spoleto, CNR, Lab. of Nuclear Geology, Pisa, pp. 9-130.

Crowell, J.C., 1982. In Geophysics Study Committee (Eds.), Climate in Earth History. National Academy Press, Washington, DC, pp. 77.

Degens, E.T., Epstein, S., 1962. Relationship between $\mathrm{O}^{18} / \mathrm{O}^{16}$ ratios in coexisting carbonates, cherts and diatomites. Amer. Assoc. Petrol. Geol. Bull. 46, 534-542.

Des Marais, D.J., 1994. The Archean atmosphere: its composition and fate. In: Condie, K.D. (Ed.), Archean Crustal Evolution. Elsevier, Amsterdam, pp. 505-523. 
Dessert, C., Dupré, B., Gaillardet, J., François, L.M., Allègre, C.J., 2003. Basalt weathering laws and the impact of basalt weathering on the global carbon cycle. Chem. Geol. 202, 257-273.

De Wit, M.J., 1998. On Archean granites, greenstones, cratons and tectonics: does the evidence demand a verdict? Precambrian Res. 91, $181-226$.

De Wit, M.J., Hart, R., Martin, A., Abbott, P., 1982. Archean abiogenic and probable biogenic structures associated with mineralized hydrothermal vent systems and regional metasomatism, with implications for greenstone belt studies. Econ. Geol. 77, 1783-1802.

D'Hondt, S., Arthur, M.A., 1996. Late Cretaceous oceans and the cool tropic paradox. Science 271, 1838-1841.

Diener, A., Ebneth, S., Veizer, J., Buhl, D., 1996. Strontium isotope stratigraphy of the Middle Devonian: brachiopods and conodonts. Geochim. Cosmochim. Acta 60, 639-652.

Douglas, R.G., Savin, S.M., 1975. Oxygen and carbon isotope analyses of Tertiary and Cretaceous microfossils from Shatsky Rise and other sites in the North Pacific Ocean. lnit. Rept. DSDP 32, 509-520.

Ebneth, S., Shields, G.A., Veizer, J., Miller, J.F., Shergold, J.H., 2001. High-resolution strontium isotope stratigraphy across the Cambrian-Ordovician transition. Geochim. Cosmochim. Acta 65, 2273-2292.

Eglington, B.M., Talma, A.S., Marais, S., Matthews, P.E., Dixon, J.G.P., 2003. Isotopic composition of Pongola Supergroup limestones from the Buffalo River gorge, South Africa: constraints on their regional depositional setting. S. Afr. J. Geol. 106, 1-10.

Fairchild, I.J., 1983. Chemical controls of cathodoluminescence of natural dolomites and calcites: New data and review. Sedimentology 30, 579-583.

Folk, R.L., 1980. Petrology of Sedimentary Rocks. Hemphill's, Austin, p. 172.

Fornari, D.J., Embley, R.W., 1995. Tectonic and volcanic controls on hydrothermal processes at the mid-ocean ridge: an overview based on near-bottom and submersible studies. In: Humphris, S.E., Zierenberg, R.A., Mullineaux, L.S., Thomson, R.E. (Eds.), Seafloor Hydrothermal Systems: Physical, Chemical, Biological, and Geological Interactions. AGU, Washington, pp. 1-46.

Frakes, L.A., 1979. Climates Throughout Geologic Time. Elsevier, Amsterdam, p. 310.

Frakes, L.A., Francis, J.E., 1988. A guide to Phanerozoic cold polar climates from high-latitude ice-rafting in the Cretaceous. Nature 333, 547-549.

Frank, T.D., Lyons, T.W., 2000. The integrity of $\delta^{18} \mathrm{O}$ records in Precambrian carbonates: a Mesoproterozoic case study. In: Grotzinger, J.P., James, N.P. (Eds.), SEPM Carbonate Sedimentation and Diagenesis in the Evolving Precambrian World. (Society for Sedimentary Geology) Spec. Pub., vol. 65, pp. 315-326. Tulsa.

Frank, T.D., Lyons, T.W., Lohmann, K.C., 1997. Isotopic evidence for the paleoenvironmental evolution of the Mesoproterozoic Helena Formation, Belt Supergroup, Montana, USA. Geochim. Cosmochim. Acta 61, 5023-5041.

Fricke, H.C., Clyde, W.C., O’Neil, J.R., Gingerich, P.D., 1998. Evidence for rapid climate change in North America during the latest Paleocene thermal maximum: oxygen isotope compositions of biogenic phosphate from the Bighorn Basin (Wyoming). Earth Planet. Sci. Lett. 160, 193-208.

Friedman, G.M., 1980. Dolomite is an evaporite mineral: evidence from the rock record and from sea-marginal ponds of the Red Sea. In: Zenger, D.H., Dunham, J.D., Ethington, R.L. (Eds.), Concepts and Models of Dolomitization Soc. Econ. Paleontologists and Mineralogists, Spec. Pub., vol. 28, pp. 69-80. Tulsa, OK.
Friedman, I., O'Neil, J.R., 1977. Compilation of stable isotope fractionation factors of geochemical interest. U. S. Geol. Surv. Prof. Pap. 440-KK.

Fritz, P., 1971. Geochemical characteristics of dolomites and the ${ }^{18} \mathrm{O}$ content of middle Devonian oceans. Earth Planet. Sci. Lett. 11, $277-282$.

Gao, G., 1993. The temperatures and oxygen-isotope composition of early Devonian oceans. Nature 361, 712-714.

Gao, G., Land, L.S., 1991. Geochemistry of Cambro-Ordovician Arbuckle limestone, Oklahoma: implications for diagenetic $\delta^{18} \mathrm{O}$ alteration and secular $\delta^{13} \mathrm{C}$ and ${ }^{87} \mathrm{Sr} /{ }^{86} \mathrm{Sr}$ variation. Geochim. Cosmochim. Acta 55, 2911-2920.

Gat, J.R., Bowser, C., 1991. The heavy isotope enrichment of water in coupled evaporative systems. In: Taylor, H.P., O’Neil, J.R., Kaplan, I.R. (Eds.), Stable Isotope Geochemistry: A Tribute to Samuel Epstein. Geochemical Society Spec. Pub., vol. 3, pp. 159-168. St Louis.

Glumac, B., Walker, K.R., 1998. A Late Cambrian positive carbonisotope excursion in the southern Appalachians: relation to biostratigraphy, sequence stratigraphy, environments of deposition, and diagenesis. J. Sediment. Res. 68, 1212-1222.

Goddéris, Y., Veizer, J., 2000. Tectonic control of chemical and isotopic composition of ancient oceans: the impact of continental growth. Am. J. Sci. 300, 437-461.

Grandjean, P., Cappetta, H., Michard, A., Albarède, F., 1987. The assessment of REE patterns and ${ }^{143} \mathrm{Nd} /{ }^{144} \mathrm{Nd}$ ratios in fish remains. Earth Planet. Sci. Lett. 84, 181-196.

Gregory, R.T., 1991. Oxygen isotope history of seawater revisited: timescales for boundary event changes in oxygen isotope composition of seawater. In: Taylor, H.P., O’Neil, J.R., Kaplan, I.R. (Eds.), Stable Isotope Geochemistry: A Tribute to Samuel Epstein. Geochem. Soc. Spec. Pub., vol. 3, pp. 65-76. St Louis.

Gregory, R.T., Taylor, H.P., 1981. An oxygen isotope profile in a section of Cretaceous oceanic crust, Samail ophiolite, Oman: evidence for $\delta^{18} \mathrm{O}$ buffering of the oceans by deep ( $>5 \mathrm{~km}$ ) seawater-hydrothermal circulation at mid-ocean ridges. J. Geophys. Res. 86, 2737-2755.

Grossman, E.L., Zhang, C., Yancey, T.E., 1991. Stable-isotope stratigraphy of brachiopods from Pennsylvanian shales in Texas. GSA Bull. 103, 953-965.

Grotzinger, J.P., Kasting, J.F., 1993. New constraints on Precambrian ocean composition. J. Geol. 101, 235-243.

Hay, W.W., DeConto, R.M., 1999. Comparison of modern and Late Cretaceous meridional energy transport and oceanology. In: Barrera, E., Johnson, C.C. (Eds.), Evolution of the Cretaceous Ocean-Climate System. Geol. Soc. Am. SP, vol. 332, pp. 283-300. Boulder, Colorado.

Hesse, R., 1990a. Origin of chert: diagenesis of biogenic siliceous sediments. In: McIlreath, I.A., Morrow, D.W. (Eds.), Diagenesis. Geosci. Can. Repr. Ser., vol. 4, pp. 227-251. Ottawa, Canada.

Hesse, R., 1990b. Silica diagenesis: origin of inorganic and replacement cherts. In: McIlreath, I.A., Morrow, D.W. (Eds.), Diagenesis. Geosci. Can. Repr. Ser., vol. 4, pp. 253-275. Ottawa, Canada.

Hill, A.C., Walter, M.R., 2000. Mid-Neoproterozoic ( 830-750 Ma) isotope stratigraphy of Australia and global correlation. Precambrian Res. 100, 181-211.

Hoffman, S.E., Wilson, M., Stakes, D.S., 1986. Inferred oxygen isotope profile of Archaean oceanic crust, Onverwacht Group, South Africa. Nature 321, 55-58.

Hofmann, H., 1999. Geons and geons. Geology 27, 855-856.

Holland, H.D., 1984. The Chemical Evolution of the Atmosphere and Oceans. Princeton University Press, Princeton, p. 582. 
Holland, H.D., 2004. The geologic history of seawater. In Elderfield, H. (Ed.). \& Holland, H.D. \& Turekian, K.K. (Exec. Eds.), Treatise on Geochemistry, Vol. 6. The Oceans and Marine Geochemistry. Elsevier Pergamon, Kidlington, Oxford, pp. 583-625.

Holmden, C., Muehlenbachs, K., 1993a. The ${ }^{18} \mathrm{O} /{ }^{16} \mathrm{O}$ ratio of 2-billionyear-old seawater inferred from ancient oceanic crust. Science 259, $1733-1736$.

Holmden, C., Muehlenbachs, K., 1993b. The origin of oxygen isotope variations in Paleozoic carbonates. Geol. Assoc. Can. Annu. Meet., Prog. Abstr., vol. A-45.

Holmden, C., Creaser, R.A., Muehlenbachs, K., Leslie, S.A., Bergstrom, S.M., 1998. Isotopic evidence for geochemical decoupling between ancient epeiric seas and bordering oceans: implications for secular curves. Geology 26, 567-570.

Hsü, K.J., Siegenthaler, C., 1969. Preliminary experiments on hydrodynamic movement induced by evaporation and their bearing on the dolomite problem. Sedimentology 12, 11-25.

Hudson, J.D., Anderson, T.F., 1989. Ocean temperatures and isotopic compositions through time. Trans. Royal. Soc. Edinb. Earth Sci. 80, 183-192.

Iacumin, P., Bocherens, H., Mariotti, A., Longinelli, A., 1996. Oxygen isotope analyses of co-existing carbonate and phosphate in biogenic apatite: a way to monitor diagenetic alteration of bone phosphate? Earth Planet. Sci. Lett. 142, 1-6.

James, N.P., Choquette, D.W., 1990a. Limestone diagenesis - the meteoric environment. In: McIlreath, I.A., Morrow, D.W. (Eds.), Diagenesis. Geosci. Can. Repr. Ser., vol. 4, pp. 35-73. Ottawa, Canada.

James, N.P., Choquette, D.W., 1990b. Limestone diagenesis - the sea floor environment. In: McIlreath, I.A., Morrow, D.W. (Eds.), Diagenesis. Geosci. Can. Repr. Ser., vol. 4, pp. 13-34. Ottawa, Canada.

James, N.P., Narbonne, G.M., Dalrymple, R.W., Kyser, T.K., 2005. Glendonites in Neoproterozoic low-latitude, interglacial, sedimentary rocks, northwest Canada: insights into the Cryogenian ocean and Precambrian cold-water carbonates. Geology 33, 9-12. doi:10.1130/ G20938.1.

Jean-Baptiste, P., Charlou, J.L., Stievenard, M., 1997. Oxygen isotope study of mid-ocean ridge hydrothermal fluids: implication for the oxygen-18 budget of the oceans. Geochim. Cosmochim. Acta 61, 2669-2677.

Joachimski, M.M., Von Bitter, P.H., Buggisch, W., 2006. Constraints on Pennsylvanian glacioeustatic sea-level changes using oxygen isotopes of conodont apatite. Geology 34, 277-280.

Johnson, W.J., Goldstein, R.H., 1993. Cambrian seawater preserved as inclusions in marine low-Mg calcite cement. Nature 232, 335-337.

Jones, D.R., Knauth, L.P., 1979. Oxygen isotopic and petrographic evidence relevant to the origin of the Arkansas Novaculite (DevonianMississippian) of Arkansas and Oklahoma. J. Sediment. Petrol. 49, 581-598.

Kah, L., 2000. Depositional $\delta^{18}$ O signatures in Proterozoic dolostones: constraints on seawater chemistry and early diagenesis. In: Grotzinger, J.P., James, N.P. (Eds.), Carbonate Sedimentation and Diagenesis in the Evolving Precambrian World. SEPM Special Publication, vol. 67, pp. 345-360. Tulsa.

Kah, L.C., Sherman, A.G., Narbonne, G.M., Knoll, A.H., Kaufman, A.J., 1999. $\delta^{13} \mathrm{C}$ stratigraphy of the Proterozoic Bylot Supergroup, Baffin Island, Canada: implications for regional lithostratigraphic correlations. Can. J. Earth Sci. 36, 313-332.

Kah, L.C., Lyons, T.W., Chesley, J.T., 2001. Geochemistry of a 1.2 Ga carbonate-evaporite succession, northern Baffin and Bylot Islands: implications for Mesoproterozoic marine evolution. Precambrian Res. $11,203-234$.
Karhu, J., Epstein, S., 1986. The implication of the oxygen isotope records in coexisting cherts and phosphates. Geochim. Cosmochim. Acta 50, $1745-1756$.

Kasting, J.F., 1987. Theoretical constraints on oxygen and carbon dioxide concentrations in the Precambrian atmosphere. Precambrian Res. 34, $205-229$.

Kasting, J.F., Ueno, S., 2006. Palaeoclimates: the first two billion years. Philos. Trans. R. Soc., B 361, 917-929.

Kasting, J.F., Howard, M.T., Wallmann, K., Veizer, J., Shields, G., Jaffrés, J., 2006. Paleoclimates, ocean depth, and the oxygen isotopic composition of seawater. Earth Planet. Sci. Lett. 252, 82-93.

Kastner, M., Gieskes, J.M., Hu, J.-Y., 1986. Carbonate recrystallization in basal sediments: evidence for convecgive flow on a ridge flank. Nature $321,158-161$

Keith, M.L., Weber, J.N., 1964. Carbon and oxygen isotopic composition of selected limestones and fossils. Geochim. Cosmochim. Acta 28, $1787-1816$.

Kennedy, M., Droser, M., Mayer, L.M., Pevear, D., Mrofka, D., 2006. Late Precambrian oxygenation; inception of the clay mineral factory. Science 311, 1446-1449.

Kinne, O., 1970. Temperature-invertebrates. In: Kinne, O. (Ed.), Marine Ecology, vol. 1. Wiley-Interscience, London, pp. 407-514.

Knauth, L.P., 1994. Petrogenesis of chert. Rev. Miner. 29, 233-258.

Knauth, L.P., 2005. Temperature and salinity history of the Precambrian ocean: implications for the course of microbial evolution. Palaeogeogr. Palaeoclimatol. Palaeoecol. 219, 53-69.

Knauth, L.P., Epstein, S., 1976. Hydrogen and oxygen isotope ratios in nodular and bedded cherts. Geochim. Cosmochim. Acta 40, 1095-1108.

Knauth, L.P., Lowe, D.R., 1978. Oxygen isotope geochemistry of cherts from the Onverwacht Group (3.4 billion years), Transvaal, South Africa, with implications for secular variations in the isotopic composition of cherts. Earth Planet. Sci. Lett. 41, 209-222.

Knauth, L.P., Lowe, D.R., 2003. High Archean climatic temperature inferred from oxygen isotope geochemistry of cherts in the $3.5 \mathrm{Ga}$ Swaziland Supergroup, South Africa. GSA Bull. 115, 566-580.

Knauth, L.P., Roberts, S.K., 1991. The hydrogen and oxygen isotope history of the Silurian-Permian hydrosphere as determined by direct measurement of fossil water. In: Taylor, H.P., O’Neil, J.R., Kaplan, I.R. (Eds.), Stable Isotope Geochemistry: A Tribute to Samuel Epstein. Geochemical Society Spec. Pub., vol. 3, pp. 91-104. St Louis.

Kohn, M.J., Schoeninger, M., Barker, W.W., 1999. Altered states: effects of diagenesis on fossil tooth chemistry. Geochim. Cosmochim. Acta 63, 2737-2747.

Kolodny, Y., Epstein, S., 1976. Stable isotope geochemistry of deep sea cherts. Geochim. Cosmochim. Acta 40, 1195-1209.

Kolodny, Y., Luz, B., 1991. Oxygen isotopes in phosphates of fossil fish - Devonian to Recent. In: Taylor, H.P., O’Neil, J.R., Kaplan, I.R. (Eds.), Stable Isotope Geochemistry: A Tribute to Samuel Epstein. Geochemical Society Spec. Pub., vol. 3, pp. 105-119. St Louis.

Kolodny, Y., Raab, M., 1988. Oxygen isotopes in phosphatic fish remains from Israel: paleothermometry of tropical Cretaceous and Tertiary shelf waters. Palaeogeogr. Palaeoclimatol. Palaeoecol. 64, 59-64.

Kolodny, Y., Luz, B., Navon, O., 1983. Oxygen isotope variations in phosphate of biogenic apatites. I. Fish bone apatite - rechecking the rules of the game. Earth Planet. Sci. Lett. 64, 398-404.

Kolodny, Y., Luz, B., Sander, M., Clemens, W.A., 1996. Dinosaur bones: fossils or pseudomorphs? The pitfalls of physiology reconstruction from apatitic fossils. Palaeogeogr. Palaeoclimatol. Palaeoecol. 126, $161-171$. 
Korte, C., Kozur, H.W., Joachimski, M.M., Strauss, H., Veizer, J., Schwark, L., 2004. Carbon, sulfur, oxygen and strontium isotope records, organic geochemistry and biostratigraphy across the Permian/Triassic boundary in Abadeh, Iran. Int. J. Earth Sci. 93, $565-581$.

Korte, C., Jasper, T., Kozur, H.W., Veizer, J., 2005a. $\delta^{18} \mathrm{O}$ and $\delta^{13} \mathrm{C}$ of Permian brachiopods: a record of seawater evolution and continental glaciation. Palaeogeogr. Palaeoclimatol. Palaeoecol. 224, 333-351.

Korte, C., Kozur, H.W., Veizer, J., 2005b. $\delta^{13} \mathrm{C}$ and $\delta^{18} \mathrm{O}$ of Triassic brachiopods and carbonate rocks as proxies for coeval seawater and paleotemperature. Palaeogeogr. Palaeoclimatol. Palaeoecol. 226, 287-306.

Kump, L.R., Arthur, M.A., Patkowski, M.E., Gibbs, M.T., Pinkus, D.S., Sheehan, P.M., 1999. A weathering hypothesis for glaciation at high atmospheric $p \mathrm{CO}_{2}$ during the Late Ordovician glaciation. Palaeogeogr. Palaeoclimatol. Palaeoecol. 152, 173-187.

Land, L.S., 1980. The isotopic and trace element geochemistry of dolomite: the state of the art. In: Zenger, D.H., Dunham, J.B., Ethington, R.L. (Eds.), Concepts and Models of Dolomitization. SEPM Special Publication, vol. 28, pp. 87-110.

Land, L.S., 1995. Oxygen and carbon isotopic composition of Ordovician brachiopods: implications for coeval seawater: discussion. Geochim. Cosmochim. Acta 59, 2843-2844.

Land, L.S., Lynch, F.L., 1996. $\delta^{18} \mathrm{O}$ values of mudrocks: more evidence for an ${ }^{18}$ O-buffered ocean. Geochim. Cosmochim. Acta 60, $3347-3352$.

Lawrence, J.R., Gieskes, J.M., Broecker, W.S., 1975. Oxygen isotope and cation composition of DSDP porewaters and the alteration of layer II basalts. Earth Planet. Sci. Lett. 27, 1-10.

Lécuyer, C., Allemand, P., 1999. Modelling of oxygen isotope evolution of seawater: implications for the climate interpretation of the $\delta^{18} \mathrm{O}$ of marine sediments. Geochim. Cosmochim. Acta 63, $351-361$.

Lécuyer, C., Fourcade, S., 1991. Oxygen isotope evidence for multistage hydrothermal alteration at a fossil slow-spreading center: the Silurian Trinity ophiolite (California, USA). Chem. Geol. 87, 231-246.

Lécuyer, C., Grandjean, P., O’Neil, J.R., Cappetta, H., Martineau, F., 1993. Thermal excursions in the ocean at the Cretaceous-Tertiary boundary (northern Morocco): $\delta^{18} \mathrm{O}$ record of phosphatic fish debris. Palaeogeogr. Palaeoclimatol. Palaeoecol. 105, 235-243.

Lécuyer, C., Grandjean, P., Sheppard, S., 1999. Oxygen isotope exchange between dissolved phosphate and water at temperatures $\leq 135^{\circ} \mathrm{C}$ : inorganic versus biological fractionations. Geochim. Cosmochim. Acta 63, 855-862.

Lee, R.W., 2003. Thermal tolerances of deep-sea hydrothermal vent animals from the Northeast Pacific. Biol. Bull. 205, 98-101.

Lenton, T.M., 2001. The role of land plants, phosphorus weathering and fire in the rise and regulation of atmospheric oxygen. Glob. Chang. Biol. 7, 613-629.

Lhomme, N., Clarke, G.K.C., Ritz, C., 2005. Global budget of water isotopes inferred from polar ice sheets. Geophys. Res. Lett. 32, L20502. doi:10.1029/2005GL023774.

Li, Y.H., 1972. Geochemical mass balance among lithosphere, hydrosphere and atmosphere. Am. J. Sci. 272, 119-137.

Lindsay, J.F., Brasier, M.D., McLoughlin, N., Green, O.R., Fogel, M., Steele, A., Mertzman, S.A., 2005. The problem of deep carbon - an Archean paradox. Precambrian Res. 143, 1-22.

Locklair, R.E., Lerman, A., 2005. A model of Phanerozoic cycles of carbon and calcium in the global ocean: evaluation and constraints on ocean chemistry and input fluxes. Chem. Geol. 217, 113-126.

Lohmann, K.C., Walker, J.C.G., 1989. The $\delta^{18}$ O record of phanerozoic abiotic marine calcite cements. Geophys. Res. Lett. 16, 319-322.
Longinelli, A., 1966. Ratios of oxygen-18: oxygen-16 in phosphate and carbonate from living and fossil marine organisms. Nature 211, 923-927.

Longinelli, A., Nuti, S., 1968a. Oxygen isotope composition of phosphates from marine formations. Earth Planet. Sci. Lett. 5, 13-16.

Longinelli, A., Nuti, S., 1968b. Oxygen-isotope ratios in phosphate from fossil marine organisms. Science 160, 879-881.

Longinelli, A., Nuti, S., 1973. Revised phosphate-water isotope temperature scale. Earth Planet. Sci. Lett. 19, 373-376.

Longinelli, A., Iacumin, P., Ramigni, M., 2002. $\delta^{18} \mathrm{O}$ of carbonate, quartz and phosphate from belemnite guards: implications for the isotopic record of old fossils and the isotopic composition of ancient seawater. Earth Planet. Sci. Lett. 203, 445-459.

Longinelli, A., Wierzbowski, H., Di Matteo, A., 2003. $\delta^{18} \mathrm{O}\left(\mathrm{PO}_{4}^{3-}\right)$ and $\delta^{18} \mathrm{O}\left(\mathrm{CO}_{3}^{2-}\right)$ from belemnite guards from Eastern Europe: implications for palaeoceanographic reconstructions and for the preservation of pristine isotopic values. Earth Planet. Sci. Lett. 209, 337-350.

Lowenstam, H., 1961. Mineralogy, $\mathrm{O}^{18} / \mathrm{O}^{16}$ ratios, and strontium and magnesium contents of recent and fossil brachiopods and their bearing on the history of the oceans. J. Geol. 69, 241-260.

Luz, B., Kolodny, Y., Kovach, J., 1984. Oxygen isotope variations in phosphate of biogenic apatites. III. Conodonts. Earth Planet. Sci. Lett. 69, 255-262.

Maliva, R.G., Knoll, A.H., Siever, R., 1989. Secular change in chert distribution: a reflection of evolving biological participation in the silica cycle. Palaios 4, 519-532.

Marshall, J.D., 1992. Climatic and oceanographic isotopic signals from the carbonate rock record and their preservation. Geol. Mag. 129, 143-160.

Marshall, J.D., Middleton, P.D., 1990. Changes in marine isotopic composition and the Late Ordovician glaciation. J. Geol. Soc. ( Lond. ) $147,1-4$.

Marshall, J.D., Brenchley, P.J., Mason, P., Wolff, A., Astini, R.A., Hints, L., Meidla, T., 1997. Global isotopic events associated with mass extinction and glaciation in the Late Ordovician. Palaeogeogr. Palaeoclimatol. Palaeoecol. 132, 195-210.

McArthur, J.M., 1985. Francolite geochemistry-compositional controls during formation, diagenesis, metamorphism and weathering. Geochim. Cosmochim. Acta 49, 23-35.

McArthur, J.M., Hamilton, P.J., Greensmith, J.T., Walsh, J.N., Boyce, A.B., Fallick, A.E., Birch, G., Benmore, R.A., Coleman, M.L., 1987. Phosphorite geochemistry - isotopic evidence for meteoric alteration of francolite on a local scale. Chem. Geol., Isot. Geosci. Sect. $65,415-425$.

McConnaughey, T., $1989 .{ }^{13} \mathrm{C}$ and ${ }^{18} \mathrm{O}$ isotopic disequilibrium in biological carbonates: I. Patterns. Geochim. Cosmochim. Acta 53, 151-162.

Middleton, P.D., Marshall, J.D., Brenchley, P.J., 1991. Evidence for isotopic change associated with Late Ordovician glaciation from brachiopods and marine cements of central Sweden. Geol. Sur. Can. Pap. 90-9, 313-321.

Mortyn, P.G., Charles, C.D., 2003. Planktonic foraminiferal depth habitat and $\delta^{18} \mathrm{O}$ calibrations: plankton tow results from the Atlantic sector of the Southern Ocean. Paleoceanography 18, 15-1-15-14.

Muehlenbachs, K., 1986. Alteration of the oceanic crust and the ${ }^{18} \mathrm{O}$ history of seawater. In: Valley, J.W., Taylor, H.P., O’Neil, J.R. (Eds.), Stable Isotopes in High Temperature Geological Processes. Reviews in Mineralogy, vol. 16. Mineralogical Society of America, pp. 425-444.

Muehlenbachs, K., 1998. The oxygen isotopic composition of the oceans, sediments and the seafloor. Chem. Geol. 145, 263-273. 
Muehlenbachs, K., Clayton, R.N., 1976. Oxygen isotope composition of the oceanic crust and its bearing on seawater. J. Geophys. Res. 81, $4365-4369$.

Mulitza, S., Dürkoop, A., Hale, W., Wefer, G., Niebler, H.S., 1997. Planktonic foraminifera as recorders of past surface-water stratification. Geology 25, 335-338.

Newell, R.E., Dopplick, T.G., 1979. Questions concerning the possible influence of anthropogenic $\mathrm{CO}_{2}$ on atmospheric temperature. J. Appl. Meteorol. 18, 822-825.

Nickel, I., 1978. The present status of cathodoluminescence as a tool in sedimentology. Miner. Sci. Eng. 10, 73-100.

Pelechaty, S.M., 1998. Integrated chronostratigraphy of the Vendian System of Siberia: implications for a global stratigraphy. J. Geol. Soc. ( Lond. ) 155, 957-973.

Perry, E.C., 1967. The oxygen isotope chemistry of ancient cherts. Earth Planet. Sci. Lett. 3, 62-66.

Perry, E.C., Lefticariu, L., 2003. Formation and geochemistry of Precambrian cherts. In Holland, H., Turekian, K. (Eds.), Treatise on geochemistry, V. 7, Sediments, diagenesis, and sedimentary rocks, F.T. Mackenzie (Volume ed.), Elsevier, pp. 99-113.

Perry, E.C., Tan, F.C., 1972. Significance of oxygen and carbon isotope variations in early Precambrian cherts and carbonate rocks of southern Africa. GSA Bull. 83, 647-664.

Perry, E.C., Ahmad, S.N., Swulius, T.M., 1978. The oxygen isotope composition of 3800 m.y. old metamorphosed chert and iron formation from Isukasia, West Greenland. J. Geol. 86, 223-239.

Peterman, Z.E., Hedge, C.E., Tourtelot, H.A., 1970. Isotopic composition of strontium in seawater throughout Phanerozoic time. Geochim. Cosmochim. Acta 34, 105-120.

Phipps Morgan, J., 1998. Thermal and rare gas evolution of the mantle. Chem. Geol. 145, 431-445.

Pierson, B.J., 1981. The control of cathodoluminescence in dolomite by iron and manganese. Sedimentology 28, 601-610.

Popp, B.N., Anderson, T.F., Sandberg, P.A., 1986a. Brachiopods as indicators of original isotopic compositions in some Paleozoic limestones. GSA Bull. 97, 1262-1269.

Popp, B.N., Anderson, T.F., Sandberg, P.A., 1986b. Textural, elemental, and isotopic variations among constituents in Middle Devonian limestones, North America. J. Sediment. Petrol. 567, 15-727.

Press, W.H., Teukolsky, S.A., Vetterling, W.T., Flannnery, B.P., 1992. Numerical Recipes in C, 2nd edition. Cambridge University Press, p. 994.

Qing, H., Veizer, J., 1994. Oxygen and carbon isotopic composition of Ordovician brachiopods: implications for coeval seawater. Geochim. Cosmochim. Acta 58, 4429-4442.

Railsback, L.B., 1990. Influence of changing deep ocean circulation on the Phanerozoic oxygen isotopic record. Geochim. Cosmochim. Acta 54, 1501-1509.

Railsback, L.B., Ackerly, S.C., Anderson, T.F., Cisne, J.L., 1990. Paleontological and isotope evidence for warm saline deep waters in Ordovician oceans. Nature 343, 156-159.

Riding, R., Liang, L., 2005. Seawater chemistry control of marine limestone accumulation over the past 550 million years. Rev. Esp. Micropaleontol. 37, 1-11.

Robert, F., Chaussidon, M., 2006. A palaeotemperature curve for the Precambrian oceans based on silicon isotopes in cherts. Nature 443, 969-972.

Rothschild, L.J., Mancinelli, R.L., 2001. Life in extreme environments. Nature 409, 1092-1101.

Rudwick, M.J.S., 1970. Living and Fossil Brachiopods. Hutchinson, London, p. 159.
Rush, P.F., Chafetz, H.S., 1990. Fabric-retentive, non-luminescent brachiopods as indicators of original $\delta^{13} \mathrm{C}$ and $\delta^{18} \mathrm{O}$ composition: a test. J. Sediment. Petrol. 60, 968-981.

Saltzman, M.R., Runnegar, B., Lohmann, K.C., 1998. Carbon isotope stratigraphy of Upper Cambrian (Steptoean Stage) sequences of the eastern Great Basin: record of a global oceanographic event. GSA BulI. 110, 285-297.

Saltzman, M.R., Ripperdan, R.L., Brasier, M.D., Lohman, K.C., Robison, R.A., Chang, W.T., Shanchi, Peng, Ergaliev, G.K., Runnegar, B., 2000. A global carbon isotope excursion (SPICE) during the Late Cambrian: relation to trilobite extinctions, organic-matter burial and sea level. Palaeogeogr. Palaeoclimatol. Palaeoecol. 162, 211-223.

Saltzman, M.R., Cowan, C.A., Runkel, A.C., Runnegar, B., Stewart, M.C., Palmer, A.R., 2004. The Late Cambrian SPICE $\left(\delta^{13} C\right)$ event and the Sauk II-Sauk III regression: new evidence from Laurentian basins in Utah, Iowa, and Newfoundland. J. Sediment. Res. 74, 366-377.

Samtleben, C., Munnecke, A., Bickert, T., Pätzold, J., 2001. Shell succession, assemblage and species dependent effects on the $\mathrm{C} / \mathrm{O}-$ isotopic composition of brachiopods - examples from the Silurian of Gotland. Chem. Geol. 175, 61-107.

Samuelsson, J., Strauss, H., 1999. Stable carbon and oxygen geochemistry of the upper Visingsö Group (early Neoproterozoic), southern Sweden. Geol. Mag. 136, 63-73.

Sanyal, A., Hemming, N.G., Hanson, G.N., Broecker, W.S., 1995. Evidence for a higher $\mathrm{pH}$ in the glacial ocean from boron isotopes in foraminifera. Nature 373, 234-236.

Savin, S.M., 1977. History of the earth's surface temperature during the last 100 million years. Annu. Rev. Earth Planet. Sci. 5, 319-355.

Savin, S.M., Yeh, H.W., 1981. Stable isotopes in ocean sediments. In: Emiliani, C. (Ed.), The Sea, vol. 7. Wiley-Interscience, New York, pp. $1521-1554$.

Schmidt, M.W., Poli, S., 1998. Experimentally based water budgets for dehydrating slabs and consequences for arc magma generation. Earth Planet. Sci. Lett. 163, 361-379.

Schmidt, G.A., Bigg, G.R., Rohling, E.J., 1999. Global Seawater Oxygen-18 Database. http://data.giss.nasa.gov/o18data/.

Schopf, J.W., Klein, C., 1992. The Proterozoic Biosphere: a Multidisciplinary Study. Cambridge University Press, New York, p. 1348.

Schrag, D.P., DePaolo, D.J., Richter, F.M., 1995. Reconstructing past sea surface temperatures: correcting for diagenesis of bulk marine carbonate. Geochim. Cosmochim. Acta 59, 2265-2278.

Shackleton, N.J., Kennett, N.J., 1975. Paleotemperature history of the Cenozoic and the initiation of Antarctic glaciation: oxygen and carbon isotope analyses in DSDP sites 277, 279, and 281. Initial. Rep. Deep Sea Drill. Proj. 29, 743-755.

Shanks III, W.C., Böhlke, J.K., Seal II, R.R., 1995. Stable isotopes in midocean ridge hydrothermal systems: interactions between fluids, minerals, and organisms. In: Humphris, S.E., Zierenberg, R.A., Mullineaux, L.S., Thomson, R.E. (Eds.), Seafloor Hydrothermal Systems: Physical, Chemical, Biological, and Geological Interactions. AGU, Washington, pp. 194-221.

Sharp, Z.D., Atudorei, V., Furrer, H., 2000. The effect of diagenesis on oxygen isotope ratios of biogenic phosphates. Am. J. Sci. 300, 222-237.

Shields, G.A., 2002. A chemical explanation for the mid-Neoproterozoic disappearance of molar-tooth structure $\sim 750$ Ma. Terra Nova 14 , $108-113$.

Shields, G.A., Kasting, J.F., 2007. Palaeoclimatology: evidence for hot early oceans? Nature 447. doi:10.1038/nature 05830 .

Shields, G.A., Veizer, J., 2002. Precambrian marine carbonate isotope database: Version 1.1. Geochem. Geophys. Geosyst. 3. doi:10.1029/ $2001 \mathrm{GC} 000266$. 
Shields, G.A., Webb, G.E., 2004. Has the REE composition of seawater changed over geological time? Chem. Geol. 204, 103-107.

Shields, G.A., Carden, G.A.F., Veizer, J., Meidla, T., Rong, J.-Y., Li, R.-Y., 2003. Sr, C and $\mathrm{O}$ isotope geochemistry of Ordovician brachiopods: a major isotopic event around the Middle-Late Ordovician transition. Geochim. Cosmochim. Acta 67, 2005-2025.

Siever, R., 1992. The silica cycle in the Precambrian. Geochem. Cosmochim. Acta 56, 3265-3272.

Silverman, S.P., 1951. The isotope geology of oxygen. Geochim. Cosmochim. Acta 2, 26-42.

Smith, M.P., Sansom, I.J., Cochrane, K.D., 2001. The Cambrian origin of vertebrates. In: Ahlberg, P. (Ed.), Major Events in Early Vertebrate Evolution: Palaeontology, Phylogeny and Development. Taylor and Francis, London, pp. 67-84.

Sofer, Z., Gat, J.R., 1975. The isotope composition of evaporating brines: effect of the isotopic activity ratio in saline solutions. Earth Planet. Sci. Lett. 26, 179-186.

Spero, H.J., Bijma, J., Lea, D.W., Bemis, B.E., 1997. Effect of seawater carbonate concentration on foraminiferal carbon and oxygen isotopes. Nature 390, 497-500.

Squire, R.J., Campbell, I.H., Allen, C.M., Wilson, C.J.L., 2006. Did the Transgondwanan Supermountain trigger the explosive radiation of animals on Earth? Earth Planet. Sci. Lett. 250, 116-133.

Stanley, S.M., 1988. Paleozoic mass extinctions: shared patterns suggest global cooling as a common cause. Am. J Sci. 288, 334-352.

Stille, P., Shields, G.A., 1997. Radiogenic isotope geochemistry of sedimentary and aquatic systems. Lecture Notes in Earth Science. Springer Verlag, p. 217.

Thompson, J.B., Newton, C.R., 1988. Late Devonian mass extinction: episodic climatic cooling or warming? In: McMillan, N.J., Embry, A.F., Glass, D.J. (Eds.), Devonian of the World. Vol. III Can. Soc. Petrol. Geol. Mem., vol. 14, pp. 29-34.

Thurston, P.C., 1994. Archean volcanic patterns. In: Condie, K.D. (Ed.), Archean Crustal Evolution. Elsevier, Amsterdam, pp. 45-84.

Tobin, K.J., Bergstrom, S.M., 2002. Implications of Ordovician ( 460 Myr) marine cement for constraining seawater temperature and atmospheric $p \mathrm{CO}_{2}$. Palaeogeogr. Palaeoclimatol. Palaeoecol. 181, 399-417.

Tobin, K.J., Walker, K.R., 1996. Ordovician low- to intermediate-Mg calcite marine cements from Sweden: marine alteration and implications for oxygen isotopes in Ordovician seawater. Sedimentology 43, $719-735$.

Tucker, M.E., 1982. Precambrian dolomites: petrographic and isotopic evidence that they differ from Phanerozoic dolomites. Geology 10, $7-12$.

Urey, H.C., Lowenstam, H.A., Epstein, S., McKinney, C.R., 1951. Measurement of paleotemperatures and temperatures of the Upper Cretaceous of England, Denmark and the southeastern United States. GSA Bull. 62, 399-416.

Usdowski, E., Hoefs, J., 1993. Oxygen isotope exchange between carbonic acid, bicarbonate, carbonate, and water: a reexamination of the data of McCrea (1950) and an expression for the overall partitioning of oxygen isotopes between the carbonate species and water. Geochim. Cosmochim. Acta 57, 3815-3818.

Van de Schootbrugge, B., Föllmi, K.B., Bulot, L.G., Burns, S.J., 2000. Paleoceanographic changes during the early Cretaceous (ValanginianHauterivian) evidence from oxygen and carbon stable isotopes. Earth Planet. Sci. Lett. 181, 15-31.

Van Kranendonk, M.J., 2006. Volcanic degassing, hydrothermal circulation and the flourishing of early life on Earth: new evidence from the Warrawoona Group, Pilbara Craton, Western Australia. Earth-Sci. Rev. 74, 197-240.
Vasconcelos, C., McKenzie, J.A., Warthmann, R., Bernasconi, S.M., 2005. Calibration of the $\delta^{18} \mathrm{O}$ paleothermometer for dolomite precipitated in microbial cultures and natural environments. Geol. Soc. Am. 33, 317-320.

Veizer, J., 1974. Chemical diagenesis of belemnite shells and possible consequences for paleotemperature determinations. Neues Jahrb. Geol. Paläontol. Abh. 147, 91-111.

Veizer, Jan, 1983. Trace elements and isotopes in sedimentary carbonates. Rev. Mineral. Geochem. 11 (1), 265-299.

Veizer, J., 1995. Oxygen and carbon isotopic composition of Ordovician brachiopods: implications for coeval seawater: reply. Geochim. Cosmochim. Acta 59, 2845-2846.

Veizer, J., 1999. Comment on " $\delta^{18} \mathrm{O}$ of mudrocks: more evidence for an ${ }^{18} \mathrm{O}$ buffered ocean," L. S. Land and F. L. Lynch Jr. Geochim. Cosmochim. Acta 63, 2309-2310.

Veizer, J., Compston, W., $1976 .{ }^{87} \mathrm{Sr} /{ }^{86} \mathrm{Sr}$ in Precambrian carbonates as an index of crustal evolution. Geochim. Cosmochim. Acta 40, 905-914.

Veizer, J., Fritz, P., 1976. Possible control of post-depositional alteration in oxygen paleotemperature determinations. Earth Planet. Sci. Lett. 33, $255-260$.

Veizer, J., Hoefs, J., 1976. The nature of ${ }^{18} \mathrm{O} /{ }^{16} \mathrm{O}$ and ${ }^{13} \mathrm{C} /{ }^{12} \mathrm{C}$ secular trends in sedimentary carbonate rocks. Geochim. Cosmochim. Acta 40, 1387-1395.

Veizer, J., Fritz, P., Jones, B., 1986. Geochemistry of brachiopods: oxygen and carbon isotopic records of Paleozoic oceans. Geochim. Cosmochim. Acta 50, 1679-1696.

Veizer, J., Hoefs, J., Lowe, D.R., Thurton, P.C., 1989. Geochemistry of Precambrian carbonates: II. Archean greenstone belts and Archean sea water. Geochim. Cosmochim. Acta 53, 859-871.

Veizer, J., Bruckschen, P., Pawellek, F., Diener, A., Podlaha, O.G., Carden, G.A.F., Jasper, T., Korte, C., Strauss, H., Azmy, K., Ala, D., 1997. Oxygen isotope evolution of Phanerozoic seawater. Palaeogeogr. Palaeoclimatol. Palaeoecol. 132, 159-172.

Veizer, J., Ala, D., Azmy, K., Bruckschen, P., Buhl, D., Bruhn, F., Carden, G.A.F., Diener, A., Ebneth, S., Goddéris, Y., Jasper, T., Korte, C., Pawellek, F., Podlaha, O.G., Strauss, H., 1999. ${ }^{87} \mathrm{Sr} /{ }^{86} \mathrm{Sr}, \delta^{13} \mathrm{C}$ and $\delta^{18} \mathrm{O}$ evolution of Phanerozoic seawater. Chem. Geol. 161, 59-88.

Veizer, J., Goddéris, Y., François, L.M., 2000. Evidence for decoupling of atmospheric $\mathrm{CO}_{2}$ and global climate during the Phanerozoic eon. Nature 408, 698-701.

Wadleigh, M.A., Veizer, J., $1992 .{ }^{18} \mathrm{O} /{ }^{16} \mathrm{O}$ and ${ }^{13} \mathrm{C} /{ }^{12} \mathrm{C}$ in lower Paleozoic articulate brachiopods: implications for the isotopic composition of seawater. Geochim. Cosmochim. Acta 56, 431-443.

Waelbroeck, C., Mulitza, S., Spero, H., Dokken, T., Kiefer, T., Cortijo, E., 2005. A global compilation of late Holocene planktonic foraminiferal $\delta^{18} \mathrm{O}$ : relationship between surface water temperature and $\delta^{18} \mathrm{O}$. Quat. Sci. Rev. 24, 853-868.

Walker, J.G.C., Lohmann, K.C., 1989. Why the oxygen isotopic composition of seawater changes through time. Geophys. Res. Lett. $16,323-326$.

Walker, J.C.G, Hays, P.B., Kasting, J.F., 1981. A negative feedback mechanism for the long-term stabilization of Earth's surface temperature. J. Geophys. Res. 86, 9776-9782.

Wallmann, K., 2001. The geological water cycle and the evolution of marine $\delta^{18} \mathrm{O}$ values. Geochim. Cosmochim. Acta 65, 2469-2485.

Wallmann, K., 2004. Impact of atmospheris $\mathrm{CO}_{2}$ and galactic cosmic radiation on Phanerozoic climatic change and marine $\delta^{18} \mathrm{O}$ record. Geochem. Geophys. Geosyst. 5, Q06004. doi:10.1029/2003GC000683.

Weber, J.N., 1955. The $\mathrm{O}^{18} / \mathrm{O}^{16}$ ratio in ancient oceans. Geokhimiya 6, 674-680.

Wenzel, B., Lécuyer, C., Joachimski, M., 2000. Comparing oxygen isotope records of Silurian calcite and phosphate $-\delta^{18} \mathrm{O}$ 
compositions of brachiopods and conodonts. Geochim. Cosmochim. Acta 64, 1859-1872.

Wilde, P., Berry, W.B.N., 1984. Progressive ventilation of the oceanspotential for return to anoxic conditions in the post-Paleozoic. In: Schlanger, S.O., Cita, M.B. (Eds.), Nature and Origin of Cretaceous Carbon Rich Facies. Academic Press, New York, pp. 209-224.

Williams, D.F., Healy-Williams, N., 1980. Oxygen isotopic-hydrographic relationships among recent planktonic foraminifera from the Indian Ocean. Nature 283, 848-852.

Winter, B.L., Knauth, L.P., 1992. Stable isotope geochemistry of cherts and carbonates from the $2.0 \mathrm{Ga}$ Gunflint Iron Formation; implications for the depositional setting, and the effects of diagenesis and metamorphism. Precambrian Res. 59, 283-313.

Wolf-Gladrow, D.A., Bijma, J., Zeebe, R.E., 1999. Model simulation of the carbonate chemistry in the microenvironment of symbiont bearing foraminifera. Mar. Chem. 64, 181-198.

Woo, K.-S., Anderson, T.F., Railsback, L.B., Sandberg, P.A., 1992. Oxygen isotope evidence for high-salinity surface seawater in the Mid-Cretaceous Gulf of Mexico: implications for warm, saline deepwater formation. Paleoceanography 7, 673-685.
Xiao, S., Knoll, A.H., Kaufman, A.J., Yin, L., Yun, Z., 1997. Neoproterozoic fossils in Mesoproterozoic rocks? Chemostratigraphic resolution of abiostratigraphic conundrum from the North China Platform. Precambrian Res. 84, 197-220.

Zeebe, R.E., 1999. An explanation of the effect of seawater carbonate concentration on foraminiferal oxygen isotopes. Geochim. Cosmochim. Acta 63, 2001-2009.

Zeebe, R.E., 2001. Seawater $\mathrm{pH}$ and isotopic paleotemperatures of Cretaceous oceans. Palaeogeogr. Palaeoclimatol. Palaeoecol. 170, 49-57.

Zeebe, R., Wolf-Gladrow, D., 2001. $\mathrm{CO}_{2}$ in Seawater: Equilibrium, Kinetics and Isotopes. Elsevier, New York, p. 346.

Zheng, Y.-F., Wu, Y.-B., Chen, F., Gong, B., Zhao, Z.-F., 2004. Zircon $\mathrm{U}-\mathrm{Pb}$ and oxygen isotope evidence for a large-scale ${ }^{18} \mathrm{O}$ depletion event in igneous rocks during the Neoproterozoic. Geochim. Cosmochim. Acta 68 (20), 4145-4165.

Zheng, Y.-F., Wu, Y.-B., Gong, B., Chen, F., Zhao, Z.-F., 2007. Tectonic driving of Neoproterozoic glaciations: evidence from extreme oxygen isotope signature of meteoric water in granite. Earth Planet. Sci. Lett. $256,196-210$ 